Golder Associates Ltd.

$1000,9406^{\text {th }}$ Avenue S.W.

Calgary, Alberta, Canada T2P 3T1

Telephone (403) 299-5600

Fax (403) 299-5606

FINAL REPORT

\title{
ALBERTA IFN STREAM CLASSIFICATION \\ ASSESSMENT PROJECT \\ VALIDATION OF THE RECOMMENDED METHOD
}

Submitted to:

Alberta Sustainable Resource Development

Alberta Environment

Fisheries and Oceans Canada

\section{DISTRIBUTION:}

1 Copy Alberta Sustainable Resource Development

1 Copy Golder Associates Ltd.

Calgary, Alberta

October 2004

04-1326-033
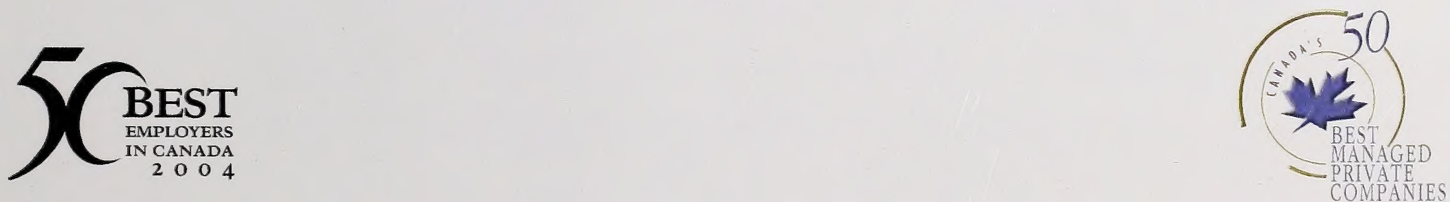
Pub No.: T/788

ISBN: 0-7785-3999-7 (Printed Edition)

ISBN: 0-7785-4000-6 (Online Edition)

Web Site: http://www3.gov.ab.ca/env/info/infocentre/publist.cfm

\section{Disclaimer}

Although prepared with funding from Alberta Environment, Alberta Sustainable Resource Development and Fisheries and Oceans Canada, the contents of this report do not necessarily reflect the views or policies of the aforementioned organizations, nor does mention of trade names or commercial products constitute endorsement or recommendation for use.

Any comments, questions or suggestions regarding the content of this document may be directed to:

Environmental Policy Branch

Alberta Environment

$4^{\text {th }}$ Floor, Oxbridge Place

9820 - 106 Street

Edmonton, Alberta, T5K 2J6

Fax: (780) $422-4192$

Additional copies of this document may be obtained by contacting:

Information Centre

Alberta Environment

Main Floor, Oxbridge Place

9820 - 106 Street

Edmonton, Alberta, T5K 2J6

Phone: $(780) 427-2700$

Fax: (780) $422-4086$

Email: env.infocent@gov.ab.ca 


\section{Acknowledgements}

The success of this project was contingent on financial support provided by: Alberta Environment and the Water Research Users Group; Alberta Sustainable Resource Development; and Fisheries and Oceans Canada.

The dedication of committee members, working groups, external reviewers and consulting teams that devoted their time and expertise to the Alberta Instream Flow Needs Classification Assessment is greatly appreciated. 
Digitized by the Internet Archive in 2016 


\section{EXECUTIVE SUMMARY}

In December 2000, Alberta Environment (AENV), with the support of Fisheries and Oceans Canada (DFO), contracted Golder Associates Ltd. (Golder) to carry out Phase I of the Alberta IFN Classification Assessment Project. The overall objective of the Project is to develop a reliable and defensible tool to establish instream flow needs (IFNs) for small to medium-sized streams in Alberta. The tool is needed to assist AENV in regulating water withdrawals from streams and rivers while protecting the aquatic environment. A rapid assessment tool is required to determine IFNs at much less cost than site-specific studies.

During the first year of Phase I (2001), Golder developed and recommended a stream classification approach that can be used to extrapolate indicators of stream hydraulics, primarily flow depth and velocity, from the stream reaches for which these characteristics are known, to unmeasured stream reaches sharing similar characteristics. A key aspect of the stream classification method was the development of a stream reach classification system to stratify stream reaches with similar hydrologic, hydraulic and geomorphic characteristics. The recommended stream classification approach involves dividing a large river basin into a number of hydrologic-geomorphic regions and grouping the stream reaches in each region into a number of classes based on two key parameters, namely Q2 (2-year flood peak flow) and Slp (reachaveraged channel bed slope). Stream reaches grouped into the same region and class should have similar hydrologic, hydraulic and geomorphic characteristics, such that stream hydraulics, characterized based on flow depths and velocities, can be extrapolated from measured to unmeasured stream reaches. Such similarity in hydraulics is necessary to ensure that the IFNs can be extrapolated from measured to unmeasured sites.

During the second year of Phase I (2002 and 2003), Golder was commissioned to test the recommended stream classification method by collecting and analyzing relevant field data at select sites in the SSRB (South Saskatchewan River Basin). The key objectives of this stage of investigation were to:

- Test the hypothesis that the stream reaches of equal Q2 and Slp within the same hydrologic-geomorphic region, have similar hydraulics, and test this hypothesis in representative regions in the SSRB and for a range of Q2; and, 
- Determine if classifying stream reaches in a region based Q2 and Slp is a valid approach, assess the sensitivity or variation of stream hydraulics with respect to Q2 and Slp in any given region, and assess the choice of class ranges for Q2 and Slp.

The field program consisted of three separate components and involved collection of relevant hydraulic, geomorphic and substrate data and information to support the above-mentioned testing, assessment and validation of the stream classification method. The data were collected in three regions (NS4, N6 and SW1) of the SSRB, representative of the expected variation of the hydrologic and geomorphic regimes in the SSRB. The data were collected by a rapid assessment method to ensure cost effectiveness. The total number of sites or stream reaches surveyed under this field program was 63 .

The field data were analyzed and relevant hydraulic modelling analysis was conducted to calculate or estimate stream hydraulic parameters (i.e., flow depths and velocities) of various discharges based on one set of measured hydraulic data during a single discharge at each stream reach. The modelling analysis involved calculation of water levels, cross-sectional average flow depths and velocities, and lateral distributions of flow depths and velocities (or cell depths and velocities). A customized modelling approach based on well-established and applicable hydraulic equations and empirical relationships, was adopted to properly accommodate the limitations of the rapid data collection procedure, while achieving maximum accuracy and efficiency of the modelling analysis.

The results of the hydraulic modelling analysis provide a basis for testing the hydraulic similarity hypothesis, validating the classification scheme, and assessing the transfer of hydraulics and WUA curves between sites. The Phase I study results support the following conclusions:

1. The proposed stream classification method is reasonably supported by the available hydraulic data for the SSRB, comparisons of the reach-averaged cell flow velocities and depths, and visual examination of the distributions of the cell flow velocities and depths. More detailed statistical analysis is recommended for Phase II when each region will be populated with additional data. Such verification is desirable to rigorously test the method and to define the error bounds and degrees of similarity more accurately. 
2. The stream reaches of similar Q2 and Slp in the same hydrologic-geomorphic region have been shown to have similar reach average cell flow velocities and depths as well as similar distributions of cell flow velocities and depths. Although the sample sizes of the available sites were insufficient for rigorous statistical testing, comparisons of the reachaveraged cell flow velocities and depths show that the hydraulics of comparable sites generally vary between $10 \%$ and $30 \%$ of the sample means, about $90 \%$ of the time.

3. Within a given hydrologic-geomorphic region, the Q2 and Slp parameters are appropriate for stream classification and are therefore appropriate for the transfer of hydraulics from measured to unmeasured streams.

4. The preliminary Q2 and Slp ranges for stream classification were suitable for initial testing. The available data show that the ranges for each class should be refined at the lower Q2 ranges for the foothills (NS4) and the lower Q2 and Slp ranges and prairie (N6) regions. Different regions may have different threshold values for grouping the stream reaches into various classes, but the general approach of classification based on ranges of Q2's and Slp's is the same for all regions. The proposed threshold values will need to be updated when more data are available for each region. It is not expected that the total number of Q2 or Slp classes would largely exceed the five classes that were initially proposed for the NS4 and N6 regions, because these two regions have few streams with very high Q2 and Slp.

5. The weighted useable area (WUA) curves for the stream reaches with similar Q2 and Slp within the same hydrologic-geomorphic region are similar to the WUA curves developed from the detailed Physical Habitat Simulation (PHABSIM) studies. This suggests that the observed variability in the distributions of the cell flow depths and velocities of the comparable, rapid assessment sites may not be a concern when predicting WUA curves within a region.

6. The results of a preliminary assessment of the protocols for transferring IFNs suggest that the WUA curves of the stream reaches within the same class are similar. The proposed stream classification scheme to group hydraulically similar stream reaches based on Q2 and Slp ranges, is therefore appropriate for general application. 
7. The WUA curves from the stream reaches belonging to different classes with the same hydrologic-geomorphic region appear very different. However, after transformation based on Q2, the WUA curves from two different Q2 classes become very similar. Therefore, a basin or streamflow parameter, such as Q2, may be used to scale IFN data within the same hydrologic-geomorphic region from measured sites to unmeasured sites.

8. The results of this Phase I study have shown that the hydraulics, WUA curves, and eventually the IFN can be transferred between stream reaches of similar classes within the same hydrologic-geomorphic region. The analysis shows a potential for scaling between adjacent stream classes within the same region. However, this would be tested and formulated in Phase II by more detailed statistical analysis when each region will be populated with additional data. An expert workshop should be used to help define potential extrapolation protocols.

9. The proposed stream classification method is recommended for successful transfer of IFNs from measured to unmeasured sites within an acceptable range of errors, compatible with the intermediate levels of efforts required for determining IFNs.

The Phase I study results support the proposition that IFNs can be derived rapidly and at relatively low cost based largely on a regionalization scheme and a stream classification method. The objectives of Phase I have been met by establishing and testing a suitable method for estimating IFNs. It is recommended that ASRD, AENV and DFO consider adopting the recommended stream classification method and proceeding to the Phase II work, which would involve an extensive data sampling program to populate the hydraulic database for all classes of all streams and rivers in Alberta, and determination of IFNs for all such classes based on hydraulic characteristics and fish suitability curves.

It is recommended that the province consider developing and implementing a strategic sampling program using a combination of rapid assessment methods for most sites and a detailed data collection approach suitable for 2D hydraulic modelling analysis for selected sites within each hydrologic-geomorphic region. Such a sampling program should populate and complete the IFN database for the SSRB and other high priority regions. This sampling program can then be expanded to include all other major river basins in the province, with priority given to regions with pressing or emerging water demand issues. 


\section{TABLE OF CONTENTS}

\section{SECTION}

\section{EXECUTIVE SUMMARY}

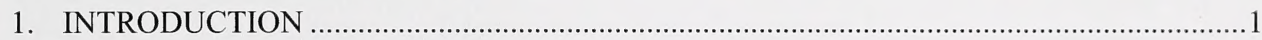

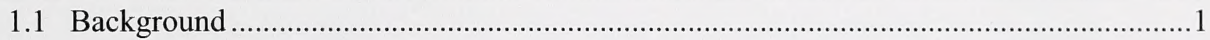

1.2 Development of Stream Classification Method during Year 1 of Phase I ........................2

1.3 Field Data Collection and Method Validation during Years 2 and 3 of Phase I................ 3

1.4 Technical Committee for Managing the Phase I Program .......................................... 4

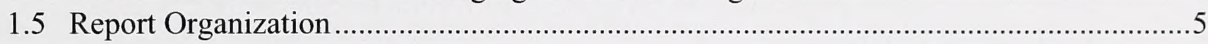

2. REVIEW OF STREAM CLASSIFICATION METHODS ….........................................

2.1 Classification and Characterization of Streams ...................................................... 6

2.2 Previous Stream Classification Scheme Considered by Alberta Environment .................6

2.3 Conceptual Approach Proposed by R2 …............................................................. 7

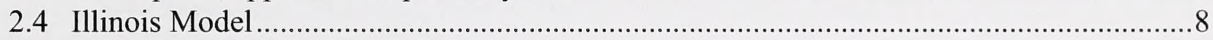

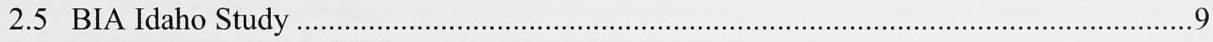

2.6 Method Developed for Pennsylvania and Maryland .................................................. 9

2.7 Stream Classification Approach for the Nooksack River Basin ...................................10

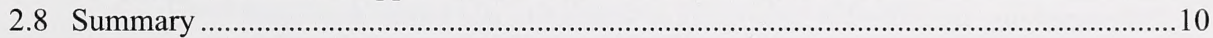

3. RECOMMENDED STREAM CLASSIFICATION METHOD FOR ALBERTA..................12

3.1 A Summary Description of the Recommended Method .............................................12

3.2 Delineation of Hydrologic-Geomorphic Regions ...................................................... 15

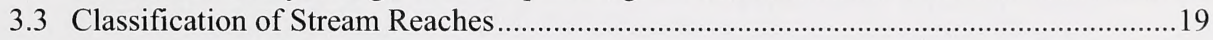

3.3.1 Two-Parameter Classification System ............................................................ 19

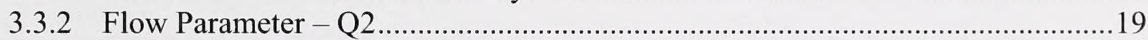

3.3.3 Reach-Averaged Stream Bed Slope …....................................................... 19

3.3.4 Estimation of Reach-Averaged Stream Bed Slope..........................................20

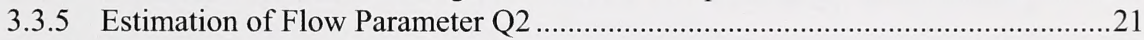

3.3.6 Classification of Stream Reaches .......................................................... 22

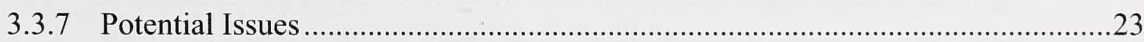

3.4 Application of the Recommended Method to the South Saskatchewan River Basin......23

3.4.1 A Description of the South Saskatchewan River Basin ....................................23

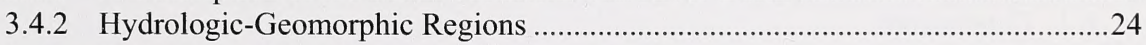

3.4.3 Estimation of Reach-Average Stream Bed Slope ..............................................24

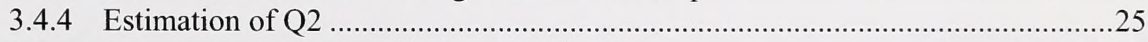

3.4.5 Summary of the Classification of Stream Reaches ...........................................25

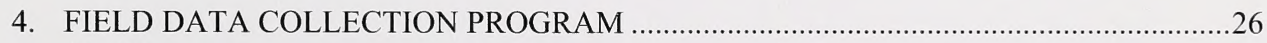

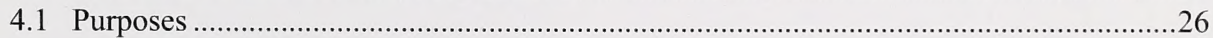

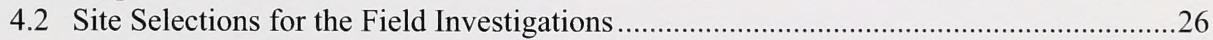

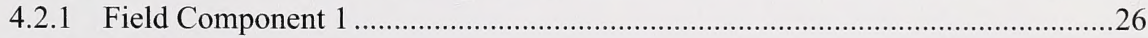

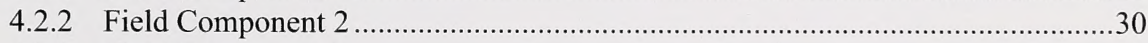

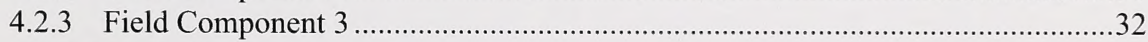

4.3 Field Data Collection Protocols .......................................................................... 36

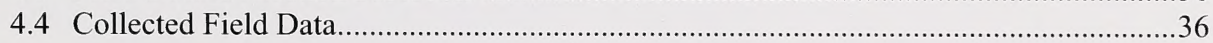


TABLE OF CONTENTS

SECTION

$\underline{\text { PAGE }}$

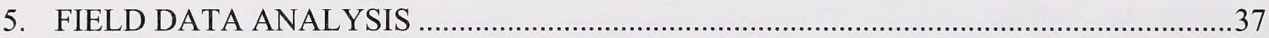

5.1 Scope

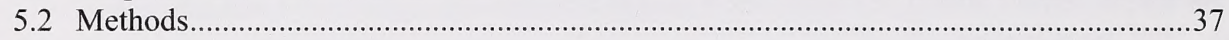

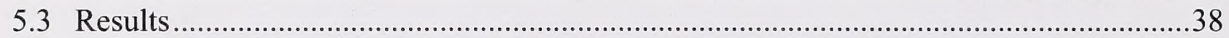

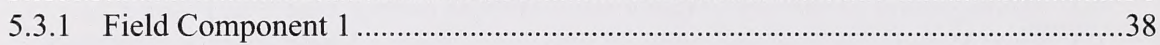

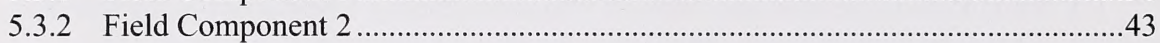

5.3.3 Conclusion Regarding the Hypothesis of Hydraulic Similarity ...........................49

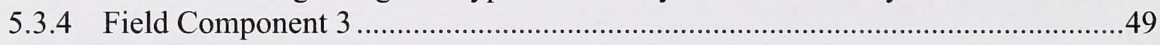

5.3.5 Conclusions Regarding Class Ranges for Q2 and Slp ......................................55

6. ASSESSMENT OF STREAM HYDRAULICS TRANSFER PROTOCOLS ......................57

6.1 Extrapolation Approaches of Other Jurisdictions .....................................................57

6.2 Preliminary Testing of Extrapolation Results for the SSRB .......................................58

7. NEXT STEPS OF THE STREAM CLASSIFICATION PROJECT AND FOR DEVELOPMENT OF THE WATER MANAGEMENT TOOLS …....................................67

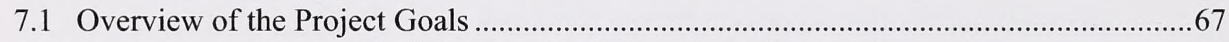

7.2 Applying the Stream Classification Method to the Entire Province ..............................69

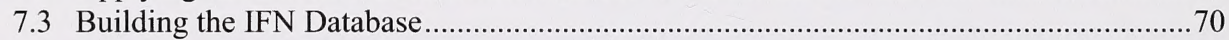

7.4 Other Ecosystem Components ........................................................................... 72

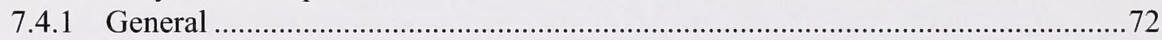

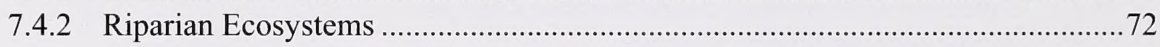

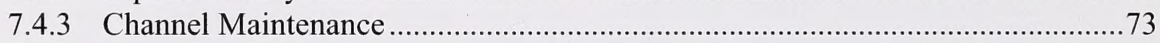

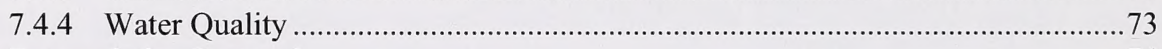

7.5 Extrapolation Protocol ...................................................................................... 74

7.6 Preliminary Assessment of Costs for Implementing the Recommended Stream

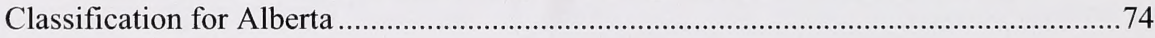

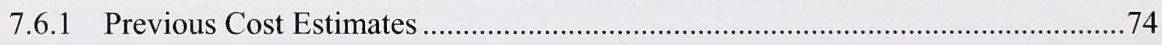

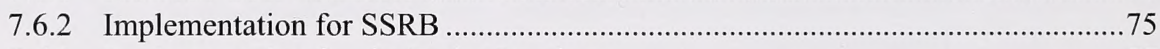

7.6.3 Implementation for the Entire Province ............................................................ 77

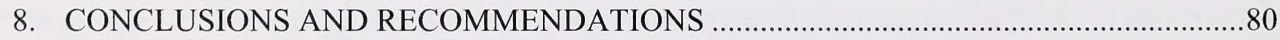

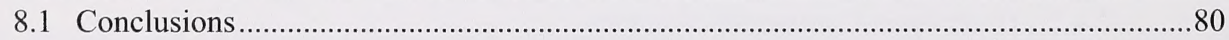

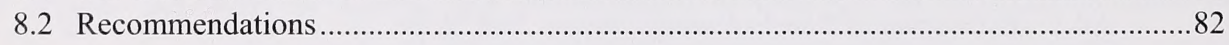

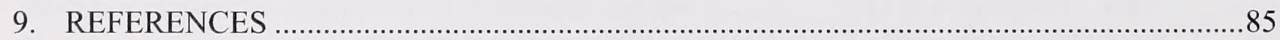




\section{LIST OF TABLES}

Table 3.1

Table 4.1

Table 4.2

Table 4.3

Table 4.4

Table 5.1

Table 5.2

Table 5.3

Table 5.4

Table 5.5

Table 5.6

Table 5.7

Table 5.8

Table 5.9

Table 5.10

Table 5.11

Table 5.12

Table 6.1

Table 7.1

Table 7.2
Scheme for Classifying Slp and Q2 in the SSRB .25

Selected Sites in Region NS4 for Field Component 1 .......................................28

Sites Selected in Regions NS4, SW1 and N6 for Field Component 2 .................31

Sites Selected in Region NS4 for Field Component 3 .......................................33

Sites Selected in Region N6 for Field Component 3 ....................................... 35

Reach-Averaged Cell Flow Velocities (m/s) and Depths $(\mathrm{m})$ for the Eight

Sites in Region NS4 (Field Component 1).....

Percent Distribution of Cell Flow Velocities $(\mathrm{m} / \mathrm{s})$ at One Discharge in

Region NS4

Percentage Distributions of Cell Flow Depths (m) at One Discharge in

Region NS4 ....

Reach-Averaged Cell Flow Velocities $(\mathrm{m} / \mathrm{s})$ and Depths $(\mathrm{m})$ at Three

Simulated Discharges for Two Q2 Different Ranges in Region NS4

Reach-Averaged Cell Flow Velocities $(\mathrm{m} / \mathrm{s})$ and Depths $(\mathrm{m})$ at Three

Simulated Discharges for Three Q2 Ranges in Region SW1 45

Reach-Averaged Cell Flow Velocities $(\mathrm{m} / \mathrm{s})$ and Depths $(\mathrm{m})$ at Three

Simulated Discharges for One Q2 Range in Region N6 .45

Percent Distributions of Cell Flow Velocities $(\mathrm{m} / \mathrm{s})$ at One Simulated

Discharge for Various Q2's in Regions NS4, SW1 and N6

Percent Distributions of Cell Flow Depths at One Simulated Discharge for Various Q2's in Regions NS4, SW1 and N6.

Percentage Distributions of Cell Flow Velocities $(\mathrm{m} / \mathrm{s})$ for the Streams

with Various Q2's in Region NS4.

Percent Distributions of Cell Flow Depths (m) for the Streams with

Various Q2's in Region NS4...

Percent Distributions of Cell Flow Velocities $(\mathrm{m} / \mathrm{s})$ for Streams with

Various Q2's and Two Classes of Slopes in Region N6

Percent Distributions of Cell Flow Depths (m) for Streams with Various

Q2's and Two Classes of Slopes in Region N6. .54

Characteristics of the PHABSIM Study Sites Used to Compare Results

from the Rapid Assessment Sites of this Project. .59

Cost Estimate for Completing the AIFNCAP for the SSRB..... .76

Cost Estimate for Completing the AIFNCAP for the Province of Alberta .78 


\section{LIST OF FIGURES}

Figure 3.1 Schematic of Hydrologic-Geomorphic Regionalization and Stream Classification ............................................................................................... 16

Figure 4.1 Hydrologic-Geomorphic Regions Initially Proposed for the SSRB ...................28

Figure 4.2 Locations of Select Sites for Field Component 1 ...........................................29

Figure 4.3 Locations of Selected Sites for Field Component 2 …......................................32

Figure 4.4 Locations of Selected Sites in Region NS4 for Field Component 3 ..................34

Figure 4.5 Locations of Selected Sites in Region N6 for Field Component 3......................35

Figure 6.1 Comparison of the WUA Results of Region NS4 for the High Q2 Range ..........60

Figure 6.2 Comparison of the WUA Results from Region NS4 for the Medium Q2

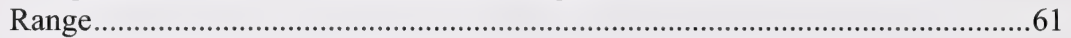

Figure 6.3 Comparison of the WUA Results from Region SW1 for the High Q2 Range

Figure 6.4 Comparison of the WUA Results within NS4 Over a Range of Q2 (45 to $88 \mathrm{~m}^{3} / \mathrm{s}$ ) without Transformation (Top) and with Transformation (Bottom) .64

Figure 6.5 Comparison of the WUA Results between Q2 Classes within Region NS4 without Transformation (Top) and with Transformation (Bottom) .66

Figure 7.1 A Schematic for Applying the Stream Classification Scheme..... .68

\section{LIST OF APPENDICES}

Appendix I Modelling of Hydraulic Conditions Associated with Various Discharges Appendix II Tables of Reach-Averaged Cell Flow Velocities and Depths for Testing Hydraulic Similarity

Appendix III Bar Charts of Percentages of Cell Flow Velocities and Depths for Testing Hydraulic Similarity

Appendix IV Tables of Reach-Averaged Cell Flow Velocities and Depths for Testing Sensitivity of Stream Classification

Appendix V Bar Charts of Percentages of Cell Flow Velocities and Depths for Testing Sensitivity of Stream Classification

Appendix VI Data Analysis Example

Appendix VII GIS Dataset Descriptions

Appendix VIII Specific Work Instructions for Field Data Collection 


\section{INTRODUCTION}

\subsection{Background}

Both the Government of Alberta and the Government of Canada have regulatory responsibilities pertaining to the use of water in the rivers and streams in Alberta. Alberta Environment (AENV) is the provincial department responsible for regulating water withdrawals from these streams and rivers. AENV, in cooperation with Alberta Sustainable Resource Development (ASRD), is currently developing water management tools in compliance with new regulatory requirements for the protection of the aquatic environment and other fluvial ecosystem components that are prescribed in the Water Act. Fisheries and Oceans Canada (DFO) is participating in the development of the water management tools that pertain to water withdrawals because DFO has a legal mandate to protect fish habitat.

An integral element of the required water management tools is the determination of quantity of water, or the Instream Flow Needs (IFNs), required for the protection of the aquatic environment in the streams and rivers. IFNs have been established for a few medium to large rivers in Alberta during the past 20 years, but site-specific IFNs for most rivers and streams in Alberta are unavailable. Therefore, AENV initiated a comprehensive program to develop tools for determining IFNs for the small to medium size streams and rivers in Alberta based on a classification/extrapolation scheme as opposed to site-specific intensive modelling efforts.

The Instream Flow Incremental Methodology (IFIM) incorporates the Physical Habitat Simulation System (PHABSIM) and is the method of choice for estimating IFNs (Bovee 1982, Bietz et al. 1985). However, a PHABSIM-based study of a particular reach of river involves extensive field investigation and analytical efforts. Such study is time-consuming and the required field work can only be conducted at certain times of the year. Conducting PHABSIMbased studies for all the streams and rivers in Alberta is logistically impossible and economically not feasible. Therefore, AENV decided to develop indirect methods of estimating IFNs for the small to medium-size streams and rivers in Alberta based on stream classification and extrapolation from self-similar rivers/streams in a homogeneous set of drainages, while recognizing that large rivers still require site-specific IFN studies. 
Alberta Environmental Protection (now AENV and ASRD), with the support of DFO, commissioned Golder Associates Ltd. (Golder) to carry out a component of the Alberta IFN Classification Assessment Project in December 2000. This Project has multiple phases and was undertaken over a number of years.

The original focus of the classification approach at the time of initial project development from 1995 to 2000 was based on developing IFNs using fish habitat as a surrogate for the protection of the aquatic ecosystem. Since the time the project began, developing IFNs in Alberta has evolved to directly incorporate multiple ecosystem components. The approach discussed in this report focuses on extrapolating flow characteristics considered important for fish habitat modelling (i.e., water depth, flow velocity, and substrate) during open water conditions, although future application of the approach may require consideration of additional ecosystem components as discussed in Section 7.

\subsection{Development of Stream Classification Method during Year 1 of Phase I}

The purpose of the Project work program in Year 1 of Phase I (2001) was to develop and recommend a method to estimate indicators of stream hydraulics, primarily flow depths and velocities of unmeasured streams, based on known indicators of stream hydraulics of measured streams. One component of the work was the development of a regionalization system to group streams with similar hydrologic and geomorphic characteristics. The other component was the development of a classification scheme to stratify streams of similar hydraulics. The purpose of such classification is to ensure that the streams of the same class within the same region should have similar hydraulic characteristics such that the relevant flow depth and velocity characteristics can be extrapolated from measured to unmeasured streams. Determining similarity in hydraulics is a necessary first step for extrapolating IFNs from measured to unmeasured sites.

There are several other stream characteristics that are important to aquatic ecosystem health. They include riparian flows, water quality and temperature, and flows necessary for flushing the stream bed sediments and maintaining river regime. However, it was the direction of the Project's Technical Advisory Committee that the first phase of the Project should focus on the primary hydraulic factors, namely flow depth, flow velocity and stream channel substrate. 
Golder reviewed and investigated a number of alternate stream classification schemes. Golder (2001) recommended a stream classification method based on (1) hydrologic-geomorphic regionalization and (2) classification of stream reaches within a hydrologic-geomorphic region based on the 2-year flood peak flow (Q2) and the average stream channel bed slope (Slp). This recommended method was subsequently applied to the South Saskatchewan River Basin (SSRB). The SSRB was divided into eight hydrologic-geomorphic regions based on this method. The streams in each region were then classified on the basis of five classes of Q2 and five classes of Slp. This method was partially tested using IFN data available at five reaches of the Belly, St. Mary and Waterton River systems.

\subsection{Field Data Collection and Method Validation during Years 2 and 3 of Phase I}

The purpose of the Project work program in Years 2 and 3 of Phase I (2002/2003 and 2003/2004) was to collect additional field data and test the validity of the classification method based on the field data. The method validation involved the following tests:

- Testing the hypothesis that the streams within the same hydrologic-geomorphic region with similar Q2 and Slp have similar hydraulics; and,

- Testing the classification scheme based on segmentation of the ranges of Q2 and Slp into a number of discrete classes for river basins ranging from 10 to $2,000 \mathrm{~km}^{2}$. This involved testing the sensitivity of the classification scheme based on the hydraulic data collected at a number of stream sites within the SSRB.

The field data collection and the method validation were carried out in stages. In December 2001, DFO commissioned Golder to design this data collection and method validation program, including a selection of study reaches for collection of the field data required for the validation testing of hydraulic similarity and the assessment of stream classification sensitivity, and development of the field data collection protocols. Golder (2002) describes the required field program, including the study reaches and the field data collection protocols.

AENV provided funding for collection of the field data in 2002 and 2003 to validate the stream classification approach and to assess the validity and sensitivity of the classification to the 
selected ranges of Q2 and Slp for each stream class. This field data collection program consisted of the following three components:

- Field Component 1: the data from this component were used to test the hypothesis that streams of equal Q2 and Slp within one hydrologic-geomorphic region have similar hydraulics;

- Field Component 2: the data from this component were used to extend the assessment of hydraulic similarity of equal Q2 and Slp to other regions and for a wider range of Q2; and,

- Field Component 3: the data from this component were used to assess the validity and sensitivity of the stream classification scheme to the choice of class ranges for Q2 and S1p.

\subsection{Technical Committee for Managing the Phase I Program}

The Phase I program of this Project was managed by Mr. Allan Locke and an inter-agency Technical Committee composed of ASRD, AENV and DFO. Members of the Technical Committee are as follows:

$\begin{array}{ll}\text { Allan Locke } & \text { ASRD } \\ \text { Dave Borutski } & \text { ASRD } \\ \text { Sal Figliuzzi } & \text { AENV } \\ \text { Wendell Koning } & \text { AENV } \\ \text { John Mahoney } & \text { AENV } \\ \text { Colin Fraser } & \text { AENV } \\ \text { Stephen Yeung } & \text { AENV } \\ \text { Patrick Marriott } & \text { AENV } \\ \text { Dave Trew } & \text { AENV } \\ \text { Peter Stevens } & \text { AENV } \\ \text { Alan Pentney } & \text { AENV } \\ \text { Jim Choles } & \text { AENV } \\ \text { Carmen de la Chrevrotierre } & \text { AENV } \\ \text { Hamid Namsechi } & \text { AENV } \\ \text { Chiadih Chang } & \text { AENV } \\ \text { Anil Gupta } & \text { AENV } \\ \text { Rick Courtney } & \text { DFO } \\ \text { Chris Katopodis } & \text { DFO } \\ \text { John Englert } & \text { DFO }\end{array}$


The timely direction and valuable advice by Mr. Locke and the Technical Committee are gratefully acknowledged by the Golder study team. This team is also grateful for the advisory services by Dr. Thomas Hardy, Director of the Institute for Natural Systems Engineering, Utah State University.

\subsection{Report Organization}

This report presents the methods and results of the Phase I program, and the conclusions and recommendations made based on the Phase I study results. The information in this report is organized as follows:

- Section 2 summarizes several stream classification methodologies that have been attempted in other jurisdictions;

- Section 3 outlines the recommended method for classifying streams to enable the transfer of hydraulic characteristics from measured to unmeasured sites;

- Section 4 describes the sites where field data were collected;

- Section 5 presents and discusses the results of the analysis of the field data;

- Section 6 presents some preliminary findings on the potential for extrapolating IFN results from measured to unmeasured streams;

- Section 7 presents the issues that would need to be considered as AENV continues its efforts to determine the IFNs for small to medium-size streams in Alberta; and,

- Section 8 presents the conclusions and recommendations of the Phase I study. 


\section{REVIEW OF STREAM CLASSIFICATION METHODS}

\subsection{Classification and Characterization of Streams}

Mosley (1987) defined classification as the process of ordering or arranging objects into groups on the basis of their characteristics or relationships. The characteristics of streams used in classification systems could vary widely, depending on the purpose of classification.

The following sections provide a review of a number of stream classification methodologies that were considered previously by AENV and others who attempted transfer of IFNs from measured to unmeasured streams. This review, initially conducted by Golder (2001), was conducted to determine the best approach to be applied in Alberta and covered the following classification schemes or approaches:

- Previous stream classification scheme considered by AENV;

- Conceptual approach proposed by R2 (De Vries et al. 1999);

- Illinois Model (Singh et al. 1986);

- $\quad$ BIA Idaho study (Resier 1995, 1998);

- Pennsylvania approach (Susquehanna River Basin Commission 1998); and,

- Nooksack River stream classification approach (Hardy 2000).

\subsection{Previous Stream Classification Scheme Considered by Alberta Environment}

AENV previously considered a stream classification system for determining IFNs based on a variety of physical and biologic parameters. In a draft internal document dated 1995, AENV outlined an approach for determining IFNs in Alberta. The approach was to classify streams on the basis of variability in flow statistics, temperature, eco-region, and biological conditions. Stream gradient and flow variability were proposed as the first variables to consider. This scheme required that data at a number of study sites be collected to supplement the available databases for the streams for which PHABSIM-based studies have already been conducted. The data were required to develop regression-type habitat-flow relationships. The document suggested that between 40 to 60 study sites might be required to develop the regression 
relationships. After validation, the regression relationships would be used to determine IFNs for unmeasured streams.

R2 Resource Consultants (R2) reviewed the proposed stream classification scheme by AENV and suggested that the proposed classification scheme should include channel slope, drainage area, precipitation, elevation, geology and land use (Reiser and De Vries 1996). R2 recommended a sampling strategy to determine the number of sites to be studied. R2 also recommended that minimum flows be first established to suit management goals. This scheme would require several rounds of calibration and validation to extrapolate IFN recommendations from measured to unmeasured stream reaches. At present, this approach is not being pursued.

\subsection{Conceptual Approach Proposed by R2}

R2 was subsequently commissioned by AENV to review alternative approaches and to recommend an appropriate classification system for Alberta. In their report, R2 presented a stream classification scheme based on several approaches described in the literature (De Vries et al. 1999). The objective of the R2 approach was to develop a conceptual stream classification system for determining IFNs at unmeasured streams in Alberta.

The method proposed by R2 included a hierarchy of relevant factors influencing IFNs extending from large to small scales. The classification scheme would involve variables descriptive of both large scale controls on fish populations, and small scale influences on individual populations. The smallest scale would reflect responses of local hydraulic (flow depth and velocity) and geomorphic (substrate) conditions to changes in instream flow rates. The classification of the entire province of Alberta would result in about 90 strata at the largest scale. Detailed IFN studies would be required at 800 to 1,000 sites based on a sample size of 8 to 12 for each large scale stratum.

The method proposed by R2 is conceptually very systematic and comprehensive. However, the number of variables involved suggests that this approach would require a considerable amount of effort and time to complete. This approach was abandoned due to the high cost and time commitments to meet existing needs within the province, although many of the principles of the approach were incorporated into the final classification approach. 


\section{$2.4 \quad$ Illinois Model}

The Illinois State Water Survey Division conducted a research into transferring IFNs from measured to unmeasured sites based on the regression formulas for the governing hydraulic parameters. The method involved streams of the same hydrologic classification.

The focus of the research by the Illinois State Water Survey Division (Singh et al. 1986) was on the development of generalized relationships between hydraulic parameters (width, depth, velocity) needed for an IFN assessment and readily available stream parameters, such as drainage area and flow duration. Such relationships would be used to calculate the expected values of flow parameters for any given stream conditions. Nine stream reaches representing a range of drainage areas within a watershed were selected for the field measurement of flow depths and velocities. The nine stream reaches were located in the three sub-basins that were judged to be hydrologically homogeneous.

Regression-type relationships were developed between discharge and drainage area for various flow durations. Regression analyses for the hydraulic parameters (width, depth, velocity) and discharges were then carried out. The distribution of water depths in a given reach was investigated by plotting depths at a given discharge on normal probability paper. The slope of the line varied with discharge and drainage area. The distribution of flow velocities was investigated in a similar manner. The joint distribution of depths and velocities was investigated by grouping velocities according to the cumulative probability of the simultaneously measured depth. A basin flow model was developed that combined the hydraulic geometry equations with the relationships defining the flow depth and velocity distributions in a riffle-pool sequence. A basin-wide probabilistic flow model could then be used to evaluate the stream network aquatic habitat for any discharge scenario.

Regression equations, by their nature, are applicable for conditions similar to those for which they were derived. This may be possible for study areas in the immediate vicinity of the area for which the equations were derived. The applications of the regression equations to other areas would not necessarily be valid. While the general principles of regression analysis may be transferable, the predictive variables will likely change from study area to study area, thus limiting the wide applicability of the approach. This approach was deemed infeasible within 
Alberta given the requirements of field sampling and potentially large number of self-similar drainage groups.

\subsection{BIA Idaho Study}

The BIA Idaho Study initially used a drainage classification scheme as a means for strategic allocation of field sampling efforts using PHABSIM to derive IFNs (Reiser 1995, 1998). The 1071 drainages in the study area were clustered based on a wide range of drainage properties derived from GIS analyses. Field sampling in each strata was undertaken using a stratified random sampling scheme. However, sample sizes proved to be insufficient for reliable statistical analysis and therefore data were combined across all strata to allow for a general multivariate statistical analysis. Multivariate techniques were used to stratify basins into a large number of strata representing groups of streams with hypothetically similar IFNs.

This study illustrates that sample size is an issue when several variables are necessary to provide predictions. It is generally advantageous when predictive variables can be reduced to the minimum number necessary. This approach was deemed infeasible in Alberta given the time and expense required to develop the necessary data.

\subsection{Method Developed for Pennsylvania and Maryland}

The method of the Susquehanna River Basin Commission was to transfer IFNs based on a calibrated hydraulic model for streams in a homogeneous physiographic region. The objective of the study carried out for the Susquehanna River Basin Commission (1998) was to develop a procedure for determining IFNs in areas of Pennsylvania and Maryland that would not require stream-specific studies.

The analysis considered the region where streams are located, stream hydrology, drainage areas, distance from headwaters to selected sites, and fish species composition. Physiographic regions were delineated on the basis of glaciation history and geology. Stream length was used as a surrogate for slope. Field data on flow rates and water surface elevations were collected at 30 study segments to allow calibration of a hydraulic model. The calibrated model was used to 
simulate flow velocities and depths for 18 discharges between the maximum and minimum median monthly flows.

\subsection{Stream Classification Approach for the Nooksack River Basin}

An empirical approach, proposed by Hardy (2000) for the Nooksack River Basin, is based on a detailed stratification of the key physical, chemical, and biological processes governing IFNs. The approach involves a strong verification and validation component. Flow regimes are broken down into four components: fish habitat base flow, fish habitat maintenance flow, riparian maintenance flow, and valley forming flow.

The conceptual framework of this approach is the delineation and validation of each flow component at a spatial scale that incorporates the variability of landform, hydrology, land use factors, water quality, and others. A basin stratification approach focuses intensive data collection and modelling efforts on representative stream types. Stratification organizes the basin into groups of similar sub-basins based on expected similarities in physical, chemical, and biological variables. Validation of the stratification procedure involves acquisition of ground truth data for key data types. Independent data are then used to assess the predictive capability of the stratification process to correctly classify stream segments into appropriate strata. The quantification of flow-dependent relationships between the physical, chemical, and biological processes can then be used to evaluate the expected conditions and responses to any proposed actions. Many of the aspects of the Nooksack approach were incorporated into the final classification approach applied to Alberta.

\section{$2.8 \quad$ Summary}

The various methodologies described above are similar in a number of respects. All the methodologies include an initial classification (whether heuristic or formalized), followed by statistical analyses of hydrologic parameters or habitat indices and primary variables influencing the IFNs. The differences pertain to the specific approaches for classification and analysis. Some of these differences are more a result of the resources available or assumed to be available (e.g., time and effort for studies) than the validity or scientific vigour of the approaches themselves. 
A consistent aspect of the various methods is regionalization. Most of the methods incorporate physiographic, hydrologic or geographic regionalization in some manner, explicitly or implicitly. Based on the review of the various approaches described in the literature, an approach based on hydrologic-geomorphic regionalization and focusing on primary stream variables affecting fish habitat (i.e., water depth, flow velocity, and substrate), seem to be most appropriate for Alberta. 


\section{RECOMMENDED STREAM CLASSIFICATION METHOD FOR ALBERTA}

\subsection{A Summary Description of the Recommended Method}

The recommended stream classification method for Alberta was developed based on a review of alternate approaches in the literature, discussions with the members of the Project's Technical Advisory Committee, and an investigation of the hydrologic, hydraulic and geomorphic conditions of the Alberta streams and rivers. The recommended stream classification system for Alberta differs from the others in that the principles of stream geomorphology were used to simplify the stream classification scheme. The recommended method involves classifying the streams in Alberta based on hydrologic-geomorphic regionalization (Golder 2001).

Regionalization is an important element of the recommended method because it reduces the number of factors that must be considered in a channel hydraulics classification system. The two major factors affecting channel hydraulics are the hydrologic regime and stream geomorphology. Major factors affecting hydrology include drainage area, climate (temperature, precipitation, freezing conditions), elevation, aspect, topography, lake areas, wetland areas, vegetation, surface soils and surficial geology. Major factors affecting stream geomorphology include channel slope, stream bed and bank materials, and sediment load.

A classification scheme incorporating all of these factors mentioned above may result in so many strata that it would not be feasible for application to the Province of Alberta. In addition, several strata may not have adequate data that need to be used for classification. However, a suitable regionalization scheme (subdividing the province into regions of homogenous hydrology and geomorphology) eliminates consideration of most of the factors for classifying streams, because most of the factors are common or similar in a properly defined region.

With a suitable hydrologic-geomorphic regionalization scheme, it is possible to simplify stream classification by eliminating most of the factors affecting stream hydraulics and keeping the following key factors:

- Hydrologic-geomorphic regions;

- Dominant discharge; and, 
- Channel bed slope.

Described below is the theoretical basis for developing a simplified classification scheme based on these key factors alone.

\section{Hydrologic-Geomorphic Regionalization}

The hydrologic-geomorphic regionalization scheme attempts to provide a region in which homogeneous hydrologic and geomorphic conditions exist for the streams of the same dominant discharge. The watersheds of the streams of the same dominant discharge within a homogeneous region are presumed to be subject to the same range of climate conditions, physiography, elevation, lake/wetland area, vegetation mix, surficial geology and sediment yield. This commonality or presumed homogeneity is believed to be valid for the purpose of classifying streams.

\section{Dominant Discharge}

Stream discharges govern the formation of a channel and affects its shape, size, bed material and sediment transport capacity. However, not all discharges are important in the channel forming process. Wolman and Miller (1960) suggested that very large flow events occur too infrequently to have much effect on the long-term channel configuration. On the other hand, low-flow events occur frequently but lack the power to shape the channel. The authors concluded that the most effective channel forming flow is the 'bankfull' discharge. The term 'bankfull discharge' is frequently used as a synonym for 'dominant discharge'. The dominant discharge has been found to have an average recurrence interval of 2 years (log normal distribution) from a study of the 71 Alberta gravel bed rivers (Bray 1972). Leopold et al. (1964) recommended the dominant discharge was the 1.5-year flood peak flow from a study of the U.S. streams.

Dominant discharge is used here as the principal parameter affecting the stream channel geometry. Streams subject to similar hydrologic regimes, defined in terms of dominant discharge, and similar geomorphic environments and slopes can be expected to be geometrically similar. 


\section{Channel Bed Slope}

Channel bed slope is a convenient surrogate for bed material for streams of equal dominant discharge, within a homogeneous hydrologic-geomorphic region. Studies show that streams of equal bed slope, hydrologic conditions and surficial geology (i.e., sediment supply and bank material) will have similar bed material (Bray 1972, and Kellerhals et al. 1972). Channel bed slope also affects stream hydraulics and is therefore a very important factor in a classification system.

\section{Other Factors}

There are many other factors that may affect channel hydraulics. Some factors like aspect, latitude, land use, and shape of drainage area, are considered to have minor effects on channel hydraulics. Other factors such as bed and bank materials, channel regime, surface geology and elevation are known to have major effects on channel hydraulics but these factors are directly related to the named dominant factors of channel bed slope, dominant discharge and hydrologicgeomorphic region. Nevertheless, the characterization of stream hydraulics based on the selected parameters and regionalization, neglecting other factors, affects the precision that can be achieved by a stream classification project.

The recommended method, based on a regionalization scheme, dominant discharge and channel slope, applies to alluvial systems. Streams controlled by bedrock or remnant boulders cannot be analyzed by this classification system. However, most of these streams are believed to be relatively small, normally smaller than the range of interest (i.e., basins less than $10 \mathrm{~km}^{2}$ ). These streams typically occur in mountainous areas and have channel bed slopes and flow velocities much higher than what would likely provide fish habitat. Important fish-bearing streams in this category will require site-specific studies.

In addition, streams that have been disturbed by human intervention may not be accurately represented by this classification system. For example, reaches where the channel dimensions have been affected by erosion protection, channelization or the banks have been trampled by cattle, etc., or where the flow regime has been altered by a dam or weir, will likely require a more detailed assessment taking these disturbances into account. 
The framework of the recommended stream classification method consists of the following three primary steps:

1. Delineate hydrologic-geomorphic regions on the basis of physiography, precipitation, and water yield;

2. Classify stream reaches on the basis of a flow parameter (dominant discharge) and reach-averaged stream bed slope within each hydrologic-geomorphic region; and,

3. Validate stream reach classification for transferring hydraulic characteristics from measured to unmeasured stream reaches.

The step-by-step procedures for hydrologic-geomorphic regionalization and stream classification are presented in the following two sections.

\subsection{Delineation of Hydrologic-Geomorphic Regions}

Figure 3.1 shows a schematic of the procedures involved in the hydrologic-geomorphic regionalization and stream classification process. Most of the data reduction, analysis and interpretation were carried out in a Geographic Information System (GIS) environment. Described below is a discussion of the major elements of the hydrologic-geomorphic regionalization method.

\section{Watershed Area Delineation}

The drainage boundary of the entire river system within the watershed area under consideration was delineated. A description of the sources of data, including the drainage boundary, and methodologies for deriving further digital products is provided in Appendix VII.

\section{Digital Elevation Model}

A Digital Elevation Model (DEM) of the entire watershed area was created. The DEM was used to identify regions on the basis of distinct ranges of elevation (e.g., Mountains, Upper Foothills, Lower Foothills, and Plains were identified). Elevation plays an important role in defining the amount of moisture that is precipitated. It also affects characteristics such as stream bed slope and stream bed material. Higher stream bed slopes and larger-size bed materials tend to occur in the upper reaches of river systems located at higher elevations. 
Figure 3.1

Schematic of Hydrologic-Geomorphic Regionalization and Stream Classification

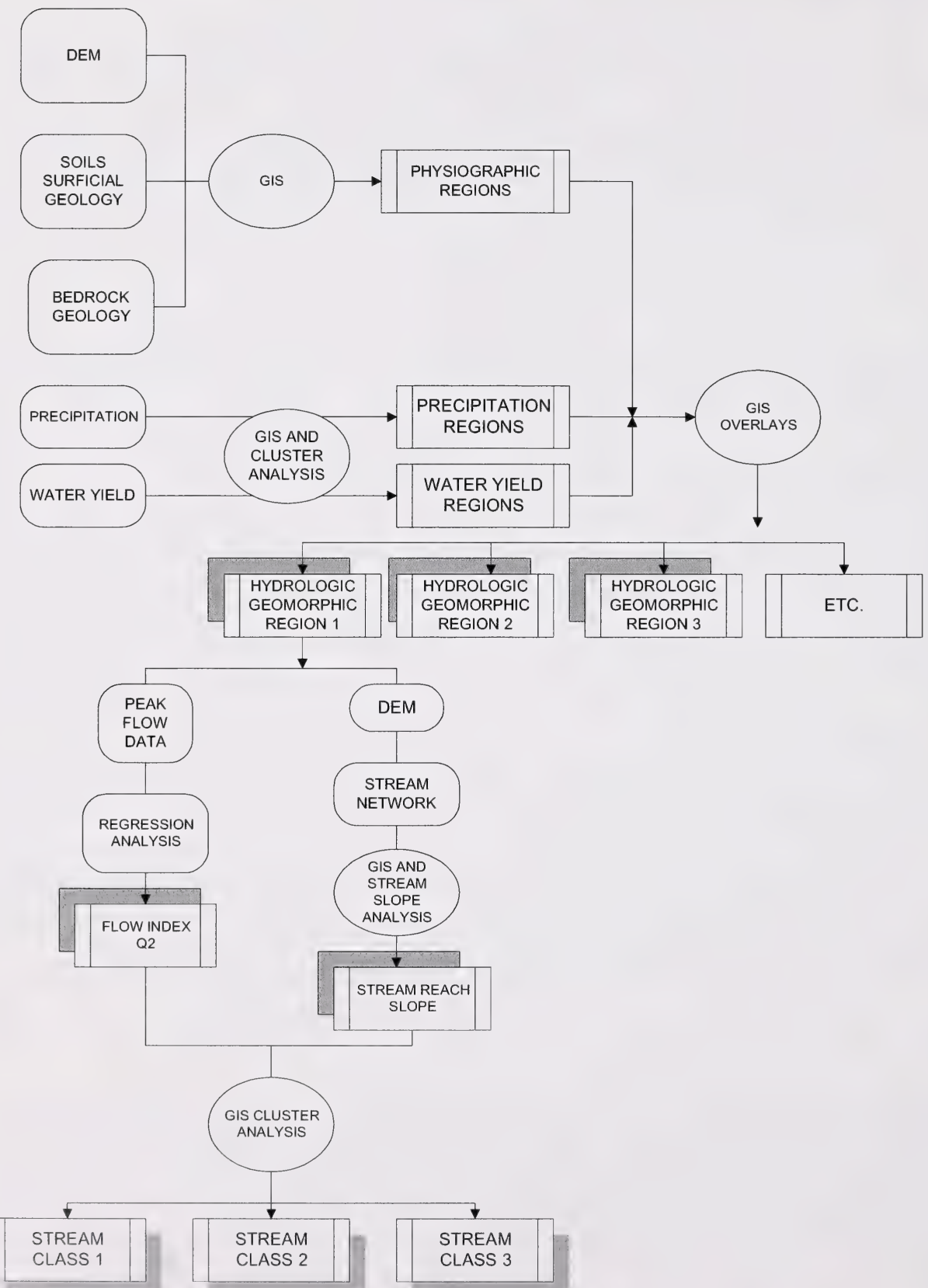




\section{Bedrock Geology, Surficial Geology and Soils}

Available bedrock geology, surficial geology and soils maps of the watershed area were used to identify regions on the basis of distinct geology and soils (i.e., Fine Sediments (silt and clay), Medium Sediments (sand), Coarse Sediments (sand and gravel), and Bedrock).

\section{Physiographic Regions}

The DEM, bedrock geology, surficial geology and soils maps were used to identify physiographic regions, which would, at a large scale of classification, be internally similar with respect to topography and stream morphology.

\section{Precipitation}

Mean Annual Precipitation (MAP) information was compiled from the data collected at the longterm precipitation stations in the watershed area. The period of record used for estimating MAP was in general from 1912 to 1995 . Stations with missing data for certain time periods were compared to nearby stations so that the data gaps could be filled prior to estimation of mean annual precipitation for the stations with missing data. GIS was then used to create a contour/grid map of MAP.

Regions with distinct precipitation characteristics were then related to the physiographic regions that had already been delineated.

\section{Evapotranspiration}

Mean Annual Evapotranspiration (MAE) information was compiled from the data collected at the long-term climate stations in the watershed area and was provided by AENV. Estimates of areal evapotranspiration were computed by AENV Hydrology/Forecasting Section from climatic parameters using the Morton Evaporation/Evapotranspiration model. Stations with data missing for certain time periods were compared to near-by stations so that the data gaps could be filled prior to estimating the MAE for the stations with missing data. GIS was then used to create a contour/grid map of MAE. 


\section{Specific Water Yield}

Specific Water Yield (SWY) at any 'grid point' in a watershed can be estimated as the difference between MAP and MAE. GIS was used to estimate SWY from the grid maps of MAP and MAE as [MAP-MAE] and to derive a contour/grid map of SWY.

Water Yield (WY) at any point in a stream is the area-weighted SWY summed over the basin area at the location of interest. The values thus obtained were verified by comparing the water yields calculated at the gauging stations with long periods of flow records.

WY information was compiled from the data collected at the long-term hydrometric gauging stations in the region encompassing the watershed area. Stations with data missing for certain time periods were compared to near-by stations so that the data gaps could be filled prior to estimating WY for the stations with missing data. The period of record used for estimating WY was generally from 1912 to 1996.

Drainage boundaries for the long-term sub-basins gauged by Water Survey of Canada (WSC) within the Watershed Area were delineated on the WY grid map. The values for WY at each of the stations were estimated using grid values obtained as [MAP-MAE]. Adjustments to the MAP and MAE were made if the WY estimated from [MAP-MAE] differed significantly from that estimated from long-term flow records. The adjustments were carried out following a procedure developed by AENV. An initial contouring of specific yield was developed using the initial estimates of [MAP-MAE]. The drainage areas of hydrometric stations were then superimposed on the preliminary specific yield map to obtain weighted yields. These values were compared to the actual areal yield, as computed from the hydrometric data, and adjustments to MAP and MAE (more often) were determined. The process was repeated and required several iterations before acceptable comparisons were obtained. More details of the procedure and on the periods of records used for estimating MAP, MAE and WY are provided in Golder (2001).

\section{Hydrologic-Geomorphic Regions}

Distinct hydrologic-geomorphic regions in the watershed area that are internally similar in terms of elevation, geology, soils, precipitation and SWY, were delineated based on MAP, MAE, SWY and physiographic regions. A cluster analysis of Q2 was also carried out to provide a quantitative 
basis for the division of the SSRB into hydrologic-geomorphic regions. Appendix I in Golder (2001) provides details and an example of the cluster analysis.

\subsection{Classification of Stream Reaches}

\subsubsection{Two-Parameter Classification System}

The adopted stream classification system involves classification of stream reaches based on the two parameters, namely, a dominant discharge (a flow parameter) and channel bed slope (reachaveraged stream bed slope). An implicit stream classification variable is the hydrologicgeomorphic region containing the stream. Hence, stream classifications apply to a given region.

\subsubsection{Flow Parameter - Q2}

According to regime theory, relationships among stream slope, width and depth of natural rivers are best developed based on a discharge of constant frequency. The literature indicates that 'dominant' discharge, approximated by the 2-year flood peak flow (Q2), has often been used to develop geomorphic relationships. Based on the discussion presented in Section 3.1, the Q2 parameter is used in the recommended stream reach classification scheme to represent a Flow Index that is indicative of stream geometry.

\subsubsection{Reach-Averaged Stream Bed Slope}

Stream channel geometry (channel width and depth), reach-averaged stream bed slope and stream bed materials are important factors that affect stream hydraulics (flow velocity and depth distributions) along a stream reach and across a stream channel. Investigations of stream geomorphic conditions in Alberta and a review of the literature on the stream geomorphology show that reach-averaged stream bed slope (Slp) can be used as an index for classifying stream hydraulics, which are a result of the combined effects of flows, channel bed slope, channel geometry and bed material.

Observed data at a number of stream sections in the South Saskatchewan River basin suggest that there is a close relationship between stream bed slope and sizes of bed materials for streams of 
equal Q2 in a homogeneous hydrologic-geomorphic region. Headwater streams in the mountains tend to be much steeper than streams in the lower foothills and plains regions, and the bed material size tends to be larger, accordingly. Geomorphic relationships in the literature indicate a strong relationship between stream bed slope and sizes of bed materials for equal dominant discharge.

Since Slp and stream bed material size are dependent on each other for alluvial streams, it is assumed that the stream reaches within the same stream reach class and the same hydrologicgeomorphic region have similar stream bed materials.

In addition, the literature and specific investigations of Alberta streams show that stream bed slope is directly related to channel geometry for the same dominant discharge and bed/bank materials.

\subsubsection{Estimation of Reach-Averaged Stream Bed Slope}

Slp can be estimated from the DEM and a 2-D digital hydrography network, or from a 3-D hydrography network of the watershed area.

Since channel bed slope varies along any stream, it is necessary to divide streams into stream reaches. Stream confluences are natural break points of reaches either ending in or starting from a confluence. The upper extremities of headwater streams are also natural break points. Midstream reach breaks can be defined in terms of changes in ground slope.

The digital stream hydrography (SLNET) provided by AENV has reach breaks with stream segments and elevation as attributes. The Slp of a stream reach can be estimated as the ratio of the difference in elevation between the upper and lower break points of the reach to the length of the stream reach between the two break points. Additional information on the GIS procedures used is provided in Appendix VII. The Rosgen stream classification scheme (Rosgen and Silvey 1998) was used to determine initial slope break points. 


\subsubsection{Estimation of Flow Parameter Q2}

The Q2 flow parameter was used as the Flow Index for the classification and was estimated from the recorded annual peak flow data at the hydrometric stations in the watershed area. WSC hydrometric stations with at least 10 years of annual maximum instantaneous (or annual daily peak) flows were selected for frequency analysis and estimation of Q2 at the gauged locations.

Graphs of Q2 against drainage area (DA) were plotted for the hydrometric stations within each hydrologic-geomorphic region. A statistical regression model was used to determine a regression equation, which relates Q2 to DA for each hydrologic-geomorphic region. Data from at least five gauging stations per hydrologic-geomorphic region were used to provide a reasonable confidence in the regression equations.

Statistical analyses were also conducted to derive relationships for Q2 in terms of DA and WY at hydrometric stations. WY was estimated based on 'integration' of a contour map of SWY (MAP - MAE) over the drainage area at the point of interest. The development of regression equations for Q2 as a function of DA and WY requires more than the five stations used for relating Q2 to DA only. The development of relationships between Q2 and (DA \& WY) required that two or more hydrologic-geomorphic regions be combined into a single hydrologic region for calculating Q2. This was the case for the hydrologic-geomorphic regions denoted as SW1, S5 and the lower half of NS4. In the latter case, regression equations relating Q2 to DA and WY were developed. Details and results are presented and discussed in Golder (2001).

The cumulative drainage area at a point just upstream of each stream reach break was estimated using the DEM of the watershed area. The appropriate regression equation for Q2 was then used to estimate Q2 at each stream reach break point. This process was repeated for each of the hydrologic regions.

Each stream reach in the stream reach network was assigned the value of its DA, WY and Q2 to allow query from the Project's GIS database. 


\subsubsection{Classification of Stream Reaches}

A stream classification system was developed to stratify stream reaches within any given hydrologic-geomorphic region into distinct classes, based on Q2 and Slp.

Limiting the number of slope classes to a practical number was an important consideration. As a first iteration in the classification of stream bed slope, the five slope classes were selected as follows:

$$
\begin{array}{ll}
\text { Slp Class 1: } & <0.003 ; \\
\text { Slp Class 2: } & 0.003-0.006 ; \\
\text { Slp Class 3: } & 0.006-0.010 ; \\
\text { Slp Class 4: } & 0.010-0.020 ; \text { and } \\
\text { Slp Class 5: } & >0.020
\end{array}
$$

Each stream reach in the Stream Reach Network was assigned a stream bed slope value and class to allow for query within the Project's GIS database.

Like the five slope classes, the Flow Indexes within the watershed area were also divided into classes. The Q2 is expected to range from $5 \mathrm{~m}^{3} / \mathrm{s}$ to $200 \mathrm{~m}^{3} / \mathrm{s}$ for the watershed sizes of $10 \mathrm{~km}^{2}$ to $2,000 \mathrm{~km}^{2}$ as defined in the Project scope of work. As a first iteration in the classification, the five classes for the Q2 were identified as follows.

$$
\begin{array}{ll}
\text { Q2 Class 1: } & <25 \mathrm{~m}^{3} / \mathrm{s} ; \\
\text { Q2 Class 2: } & 25-50 \mathrm{~m}^{3} / \mathrm{s} ; \\
\text { Q2 Class 3: } & 50-100 \mathrm{~m}^{3} / \mathrm{s} ; \\
\text { Q2 Class 4: } & 100-200 \mathrm{~m}^{3} / \mathrm{s} ; \text { and, } \\
\text { Q2 Class 5: } & >200 \mathrm{~m}^{3} / \mathrm{s} .
\end{array}
$$

It was understood that the number of classes for Slp and Q2 may need to be adjusted during the validation/field verification process, as discussed later in this report. 
GIS query tools were used to extract the stream reach identifier, Slp, and Q2 for each stream reach in the stream reach network in each of the hydrologic-geomorphic regions. Each stream reach was 'classified' on the basis of the Q2 and Slp classes described above, considering each hydrologic-geomorphic region separately. Each combination of Slp and Q2 was given a Stream Reach Class Index (1-1, 3-2, 4-3, etc.), where 3-2 would identify a stream reach with slope of Class 3 and Q2 of Class 2. The stream reaches in the stream reach network were labelled accordingly. The stream reach classification and assignment of stream reach class index was conducted for each hydrologic-geomorphic region. A stream reach classification map for the entire watershed area was then created. The frequency distribution of each stream class for each hydrologic-geomorphic region is provided in Golder (2001).

\subsubsection{Potential Issues}

The Slp and Q2 of stream reaches for stream class at the extreme end of the classification range (particularly Slope Class 1 and Q2 Class 1) can vary by large percentages within one class. Large differences in Slp and Q2 will affect the stream flow velocity and depth distributions in a crosssection and along a reach.

One option is to accept a relatively 'large' degree of variation in the hydraulic parameters between any two streams being compared. This might be acceptable if the project accuracy criteria are relaxed. Another option is to increase the number of classes for both Slp and Q2. This could minimize the error associated with variability within classes. However, it may result in an impractical classification scheme with many classes that require excessive field data collection.

\subsection{Application of the Recommended Method to the South Saskatchewan River Basin}

\subsubsection{A Description of the South Saskatchewan River Basin}

The SSRB includes the major sub-basins of the Bow, Red Deer, Oldman and South Saskatchewan rivers (Alberta Environment 2000). The first three river basins begin in the Rocky Mountains, generally flow eastward through the foothills and the prairie. The combined area of the river basins is $121,095 \mathrm{~km}^{2}$, of which $41 \%$ comprises of the Red Deer River sub-basin, $22 \%$ comprises 
the Oldman River sub-basin, 21\% comprises the Bow River sub-basin, and $16 \%$ comprises miscellaneous drainage areas of the South Saskatchewan River. All of the province's thirteen irrigation districts are located within the South Saskatchewan River Basin. The mean annual discharge from the basin into the Province of Saskatchewan is 9,280,000 dam ${ }^{3}$ (approximately $294 \mathrm{~m}^{3} / \mathrm{s}$ or a mean annual water yield of $77 \mathrm{~mm}$ ).

The following subsections describe the application of the adopted stream classification method to the SSRB.

\subsubsection{Hydrologic-Geomorphic Regions}

Examination of the DEM, geology, MAP and SWY maps for the SSRB indicates that there are four distinct zones from west to east, namely Mountains, Foothills/Lower Foothills, Transition of Foothills to Prairie, and Prairie. There is also a North-South trend, especially in terms of elevations in the mountains region and of stream substrate in the foothills and prairie regions. The SSRB can be divided into eight hydrologic-geomorphic regions to suit regions of similar topography, geology, and specific water yield. The adopted stream classification method is based on the assumption that within each of these regions, streams of equal Slp and Q2 have similar hydraulics and that streambed material is also similar for streams of equal Slp and Q2.

\subsubsection{Estimation of Reach-Average Stream Bed Slope}

AENV provided for this study a digital single-line stream hydrography database (SLNET), derived at the 1:20,000 scale. The SLNET had elevation attributes attached to the nodes of the arcs defining the stream network. However, upon closer examination, it was determined that the elevation values were set to zero (0). Another aspect of SLNET was that it did not 'line up' perfectly with the DEM. Consequently, drainage areas could not be delineated automatically from the GIS for any point on the SLNET.

To address these deficiencies, the DEM was used to derive the stream hydrography for the SSRB. The slope of each stream reach was calculated as the ratio of the elevation difference to the distance between their two nodes. A reach was defined as the stream segment from the source or 
confluence with a stream to the next downstream confluence. The reach-averaged stream bed slope was defined in terms of the change in elevation between two consecutive confluences.

\subsubsection{Estimation of Q2}

It is commonly recognized that Q2 is a function of drainage area, watershed slope, stream slope, drainage density, water yield, vegetative cover, lake/wetland are and many other parameters. The usual approach in regression analysis is to determine hydrologic regions on the basis of physiography, hydrology and climate, where some of the predictive parameters can be assumed to be essentially 'homogeneous'. In effect, the hydrologic regions become homogeneous with respect to these parameters, and the regression analysis can be carried out for each region with a limited number of predictive parameters in the regression equation. Often, drainage area becomes the only statistically significant variable in the regression equation for estimating Q2, depending on the suitability of the regionalization scheme.

AENV has compiled the annual maximum instantaneous flows at about 70 hydrometric stations in the SSRB. A frequency analysis of the data was carried out using the Pearson Type III probability distribution function as the fitting distribution to obtain estimates of Q2. Regression equations between Q2, drainage area (DA) and water yield (WY) were derived for each of the eight hydrologic-geomorphic region of the SSRB.

\subsubsection{Summary of the Classification of Stream Reaches}

The stream reaches in the SSRB were classified on the basis of Slp and Q2 as discussed above. The classification scheme is summarized in Table 3.1.

Table 3.1

Scheme for Classifying SIp and Q2 in the SSRB

\begin{tabular}{|c|c|c|c|}
\hline Class & Q2 Range $\left(\mathbf{m}^{\mathbf{3}} / \mathbf{s}\right)$ & Class & SIp Range \\
\hline \hline $\mathbf{1}$ & $<25$ & $\mathbf{1}$ & $<0.003$ \\
\hline $\mathbf{2}$ & $25-50$ & $\mathbf{2}$ & $0.003-0.006$ \\
\hline $\mathbf{3}$ & $50-100$ & $\mathbf{3}$ & $0.006-0.01$ \\
\hline $\mathbf{4}$ & $100-200$ & $\mathbf{4}$ & $0.01-0.02$ \\
\hline $\mathbf{5}$ & $>200$ & $\mathbf{5}$ & $>0.02$ \\
\hline
\end{tabular}




\section{FIELD DATA COLLECTION PROGRAM}

\subsection{Purposes}

The field data collection program consisted of three components for three specific purposes. Data were collected separately for each specific purpose. The data of Field Component 1 were collected to test the hypothesis that the streams within a given hydrologic-geomorphic region and of equal Q2 and Slp, have similar hydraulics. The data of Field Component 2 were collected to extend the assessment of hydraulic similarity to other regions and for a wider range of Q2. The data of Field Component 3 were collected to determine the sensitivity of the stream classification scheme to the choice of class ranges for Q2 and Slp.

\subsection{Site Selections for the Field Investigations}

\subsubsection{Field Component 1}

\section{Minimum Number of Sites for Field Component 1}

The scope of the field investigation was established so that the hypothesis could be validated based on a measure of statistical reliability. The reliability criteria were established by the Project Steering Committee. Based on the established criteria, the hydraulics of a stream reach are considered to be similar to the hydraulics of another stream reach when:

- the reach-averaged cell flow velocity and depth, for a range of discharges, do not differ from one reach to the other by more than $10 \%, 80 \%$ of the time; and,

- the frequencies for any bin class of cell flow velocity and depth, for a range of discharges, do not differ by more than $10 \%, 80 \%$ of the time.

Repeated measurements of the mean cell flow velocity or depth at a particular transect in a stream and at a constant discharge should yield values that can be expected to have a standard deviation of less than $10 \%$ of the mean value. Estimation of IFNs using the Instream Flow Incremental Methodology (IFIM) must account for the hydraulic conditions at most mesohabitat types (pools, riffles, runs, $c k$.) in a representative reach. In this case, the calculated reach-averaged cell flow velocity or depth based on select transects representing the various mesohabitat types, is expected 
to have a greater range of deviation from that for the mean cell flow velocity or depth at a single transect. This range of deviation from the reach-averaged mean value is generally unknown.

In the absence of reliable population statistics, an estimate of this variability was made by analyzing the flow velocity and depth data collected and simulated at the sites where the IFN assessments were carried out. Results of this analysis suggest that an average of approximately 11 reaches may be needed to obtain the reach-averaged cell flow velocity or depth to within $10 \%$ of its true value, $80 \%$ of the time.

\section{Selected Sites for Field Component 1}

A GIS database of Q2 and Slp for the stream reaches within the SSRB was developed as part of Year 1 - Phase I of the IFN Project (Golder 2001). This database was queried to identify groups of stream reaches of equal Q2 and equal Slp within each of the eight hydrologic-geomorphic regions of the SSRB. Figure 4.1 shows the hydrologic-geomorphic regions of the SSRB.

It was not possible to select the estimated minimum number of stream reaches (11) with exactly the same Q2 as well as exactly the same Slp required to do a statistically valid analysis of the hypothesis. Therefore, the groupings of the stream reaches were made such that, within a given hydrologic-geomorphic region, the Q2's in a group would be within $10 \%$ of one another, and the Slp's would be within $15 \%$ of one another.

The sets of stream reaches with similar Q2 and Slp were assessed in terms of site accessibility, potential streamflow regulation, and regional flow information. This assessment showed that only one set of eight stream reaches within the NS4 hydrologic-geomorphic region (Foothills) had the highest potential for a successful field data collection program. The number of potential sites available for the data collection was less than the estimated minimum sample size of 11 . The eight sites selected in the NS4 region for the data collection under Field Component 1, are listed in Table 4.1. The "Q2-range" in Column 2 of Table 4.1 is explained in Section 4.2.2. Figure 4.2 shows the locations of the selected sites. 
Figure 4.1

Hydrologic-Geomorphic Regions Initially Proposed for the SSRB

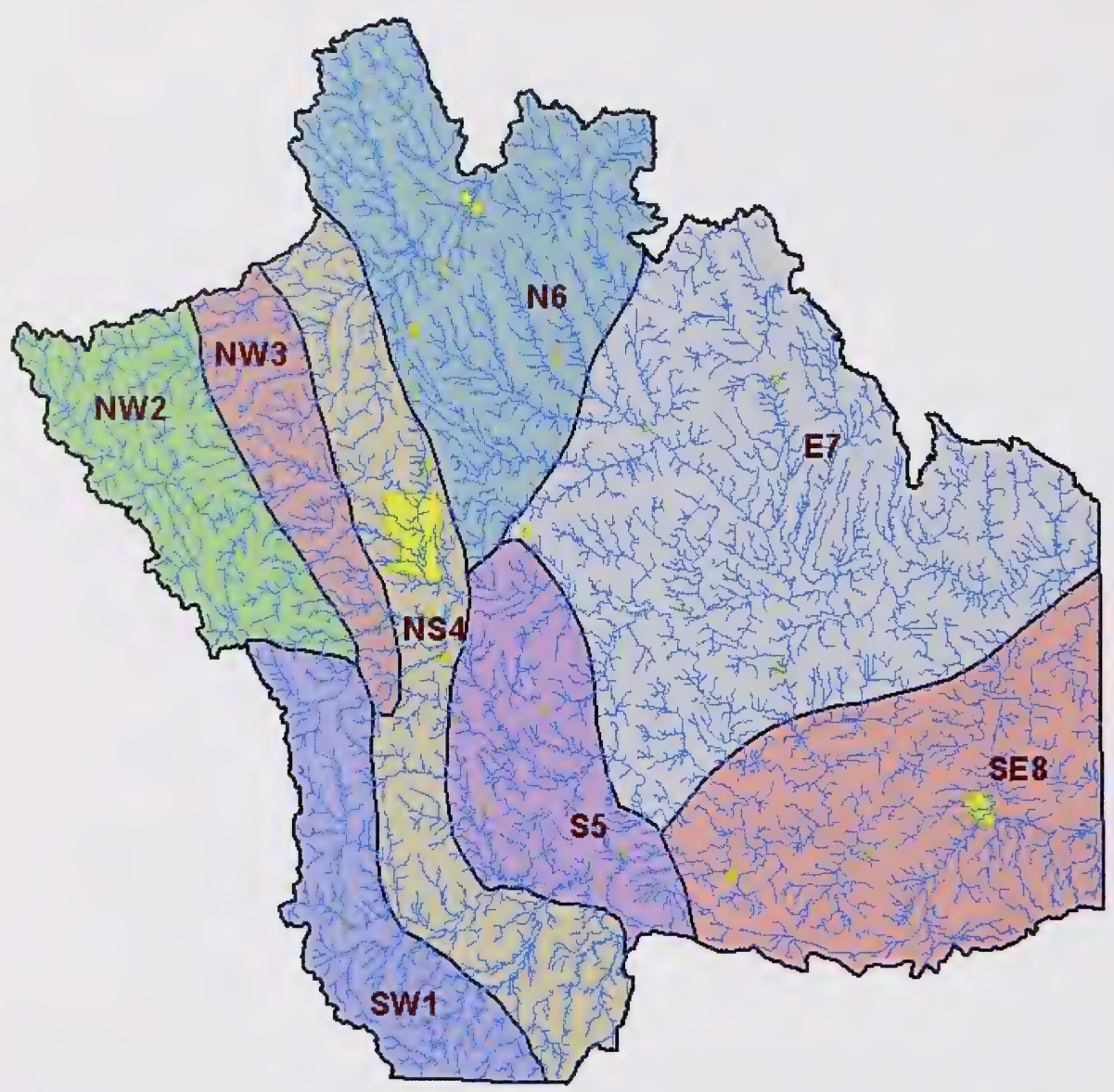

Table 4.1

Selected Sites in Region NS4 for Field Component 1

\begin{tabular}{|l|l|l|c|c|c|c|c|c|}
\hline Region & $\begin{array}{c}\text { Q2- } \\
\text { Range }\end{array}$ & \multicolumn{1}{|c|}{ Reach Name } & $\begin{array}{c}\text { Easting UTM } \\
\text { Zone 12 } \\
\text { NAD83 }\end{array}$ & $\begin{array}{c}\text { Northing } \\
\text { UTM Zone 12 } \\
\text { NAD83 }\end{array}$ & $\begin{array}{c}\text { Drainage } \\
\text { Area } \\
\left.\mathbf{k m}^{2}\right)\end{array}$ & $\begin{array}{c}\text { GIS } \\
\text { Estimated } \\
\text { Q2 }\left(\mathbf{m}^{\mathbf{3}} / \mathbf{s}\right)\end{array}$ & $\begin{array}{c}\text { GIS } \\
\text { Estimated } \\
\text { Reach Slope }\end{array}$ & $\begin{array}{c}\text { Nominal } \\
\text { Annual } \\
\text { Flow }\left(\mathbf{m}^{\mathbf{3}} / \mathbf{s}\right)\end{array}$ \\
\hline NS4 & Low & East Stony River & 238,054 & $5,762,384$ & 110 & 11 & 0.004 & 1 \\
\hline & & Raven River & 232,157 & $5,771,692$ & 100 & 11 & 0.006 & 1 \\
\hline & & Schrader Creek & 260,092 & $5,762,130$ & 90 & 10 & 0.004 & 1 \\
\hline & & Beaverdam Creek & 268,076 & $5,701,315$ & 108 & 12 & 0.004 & 1 \\
\hline & & Pine Creek & 282,502 & $5,637,059$ & 112 & 11 & 0.004 & 1 \\
\hline & & Callum Creek & 274,234 & $5,533,445$ & 117 & 11 & 0.004 & 1 \\
\hline & & Mosquito Creek & 288,486 & $5,590,443$ & 118 & 12 & 0.005 & 1 \\
\hline
\end{tabular}


Figure 4.2

Locations of Select Sites for Field Component 1

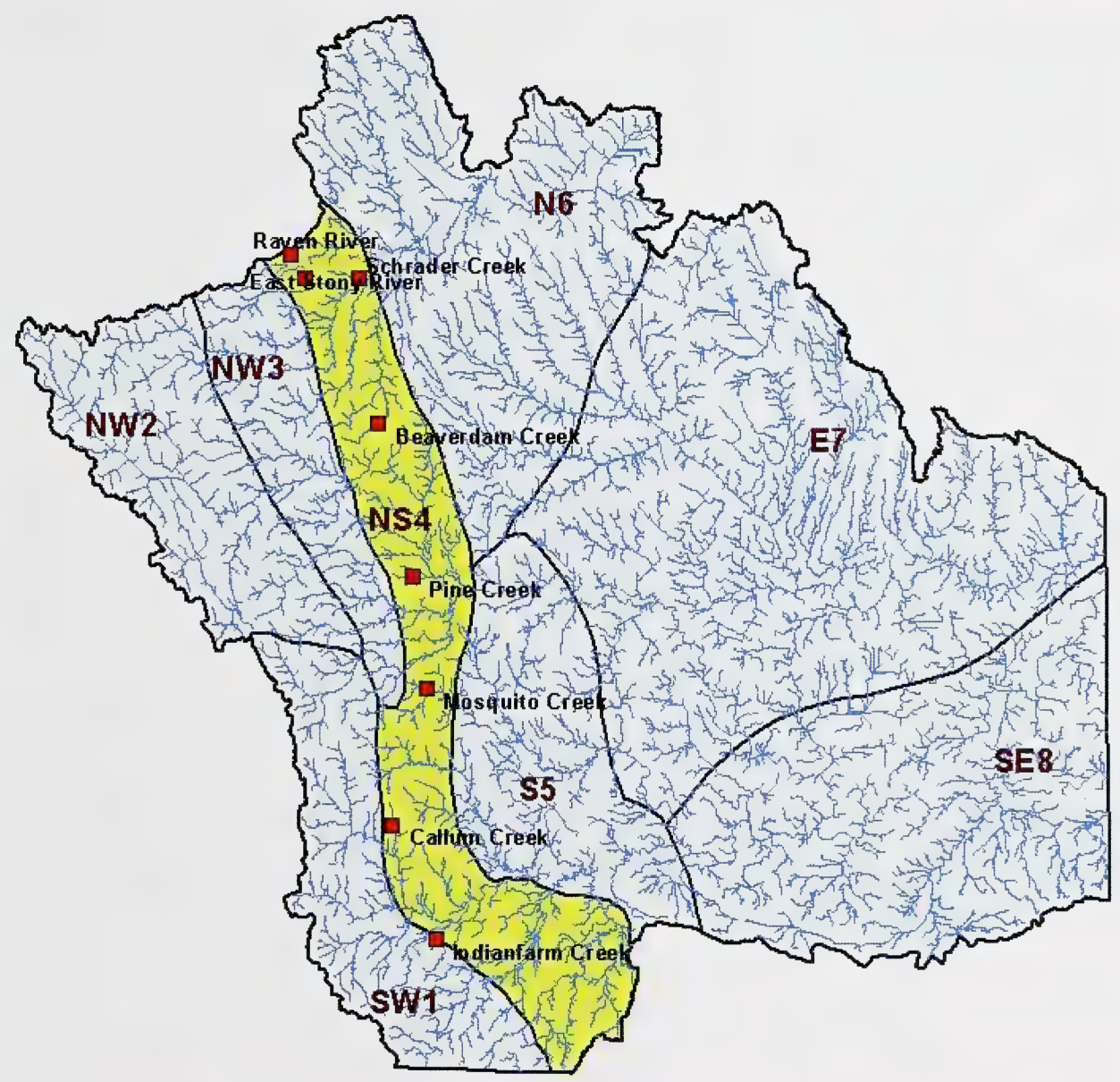




\subsubsection{Field Component 2}

Ideally, an average of about 11 stream reaches would be necessary for each range of Q2 and for each hydrologic-geomorphic region to validate the hydraulic similarity hypothesis for the entire SSRB. However, the budget and time limitations restricted the number of stream reaches that could be included in the field program under Field Component 2. In consideration of the technical requirements and the constraints of time and budget, the 'triplicates' of stream reaches with similar Q2 for three ranges of Q2 within three representative regions were selected for extending the same field investigation and analysis of Field Component 1 to other regions of the SSRB and for a wider range of Q2 for Field Component 2.

In each of the three regions, three reaches have similar Q2's in the high range of Q2 for that particular region, three reaches have similar Q2 in the middle range, and three reaches have similar Q2's in the low range. As for Field Component 1, similarity in Q2 is defined as Q2 being less the $10 \%$ of one another, and similarity in Slp is defined as Slp being less than $15 \%$ of one another.

For Field Component 2, the objective was to select 9 stream reaches in each of the 3 hydrologicgeomorphic regions for a total of 27 stream reaches for the field data collection. Three regions were selected, one in the Mountains (SW1), one in the Foothills (NS4), and one in the Prairies (N6). These regions represent the range of hydrologic and geomorphic variability in the eight hydrologic-geomorphic regions within the SSRB. The selected sites are presented in Table 4.2. The locations of the selected sites are shown in Figure 4.3. In region N6, the required number of reaches at Q2's in the medium and high ranges could not be obtained because these stream classes were not found to exist in the GIS stream classification map. Therefore, only three reaches with Q2's in the low range were selected for the field data collection in region N6. 
Table 4.2

Sites Selected in Regions NS4, SW1 and N6 for Field Component 2

\begin{tabular}{|c|c|c|c|c|c|c|c|c|}
\hline Region & Q2-Range & Reach Name & $\begin{array}{l}\text { Easting } \\
\text { UTM Zone } 12 \\
\text { NAD83 }\end{array}$ & $\begin{array}{l}\text { Northing } \\
\text { UTM Zone } 12 \\
\text { NAD83 }\end{array}$ & $\begin{array}{l}\text { Drainage } \\
\text { Area } \\
\left(\mathrm{km}^{2}\right) \\
\end{array}$ & $\begin{array}{l}\text { GIS } \\
\text { Estimated } \\
\text { Q2 }\left(\mathrm{m}^{3} / \mathrm{s}\right)\end{array}$ & \begin{tabular}{|l} 
GIS \\
Estimated \\
Reach \\
Slope \\
\end{tabular} & $\begin{array}{l}\text { Nominal } \\
\text { Mean } \\
\text { Annual } \\
\text { Flow } \\
\left(\mathrm{m}^{3} / \mathrm{s}\right) \\
\end{array}$ \\
\hline \multirow[t]{14}{*}{ NS4 } & Low & East Stony River & 238,054 & $5,762,384$ & 110 & 11 & 0.004 & 1 \\
\hline & & Raven River & 232,157 & $5,771,692$ & 100 & 11 & 0.006 & 1 \\
\hline & & Schrader Creek & 260,092 & $5,762,130$ & 90 & 10 & 0.004 & 1 \\
\hline & & Beaverdam Creek & 268,076 & $5,701,315$ & 108 & 12 & 0.004 & 1 \\
\hline & & Pine Creek & 282,502 & $5,637,059$ & 112 & 11 & 0.004 & 1 \\
\hline & & Callum Creek & 274,234 & $5,533,445$ & 117 & 11 & 0.004 & 1 \\
\hline & & Mosquito Creek & 288,486 & $5,590,443$ & 118 & 12 & 0.005 & 1 \\
\hline & & Indianfarm Creek & 292,289 & $5,485,294$ & 100 & 10 & 0.004 & 1 \\
\hline & Medium & Dogpound Creek & 263,763 & $5,709,143$ & 287 & 24 & 0.004 & 2.5 \\
\hline & & Fish Creek & 272,328 & $5,646,614$ & 324 & 26 & 0.005 & 2.5 \\
\hline & & Willow Creek & 279,083 & $5,565,693$ & 312 & 26 & 0.004 & 2.5 \\
\hline & High & James River & 246,599 & $5,759,316$ & 831 & 57 & 0.004 & 8.5 \\
\hline & & Elbow River & 263,616 & $5,659,682$ & 984 & 65 & 0.004 & 8.5 \\
\hline & & Little Red Deer R. & 266,110 & $5,746,060$ & 914 & 62 & 0.004 & 8.5 \\
\hline
\end{tabular}

\begin{tabular}{|c|c|c|c|c|c|c|c|c|}
\hline Region & Q2-Range & Reach Name & $\begin{array}{l}\text { Easting } \\
\text { UTM Zone } 12 \\
\text { NAD83 }\end{array}$ & $\begin{array}{l}\text { Northing } \\
\text { UTM Zone } 12 \\
\text { NAD83 }\end{array}$ & $\begin{array}{l}\text { Drainage } \\
\text { Area } \\
\left(\mathrm{km}^{2}\right) \\
\end{array}$ & $\begin{array}{l}\text { GIS } \\
\text { Estimated } \\
\text { Q2 }\left(\mathrm{m}^{3} / \mathrm{s}\right)\end{array}$ & $\begin{array}{l}\text { GIS } \\
\text { Estimated } \\
\text { Reach } \\
\text { Slope } \\
\end{array}$ & $\begin{array}{l}\text { Nominal } \\
\text { Mean } \\
\text { Annual } \\
\text { Flow } \\
\left(\mathrm{m}^{3} / \mathrm{s}\right)\end{array}$ \\
\hline \multirow[t]{9}{*}{ SW1 } & Low & Highwood River & 229,451 & $5,600,700$ & 135 & 10 & 0.013 & 2 \\
\hline & & Oldman River & 243,035 & $5,550,946$ & 140 & 11 & 0.012 & 2 \\
\hline & & Dutch Creek & 253,088 & $5,533,576$ & 147 & 11 & 0.012 & 2 \\
\hline & Medium & Crowsnest River & 245,148 & $5,503,786$ & 233 & 21 & 0.005 & 2.5 \\
\hline & & Castle River & 257,803 & $5,469,420$ & 204 & 18 & 0.006 & 2.5 \\
\hline & & Lee Creek & 327,780 & $5,447,995$ & 210 & 20 & 0.006 & 2.5 \\
\hline & Very High & Crowsnest River & 254,448 & $5,498,425$ & 450 & 60 & 0.006 & 5.5 \\
\hline & & Highwood River & 240,930 & $5,587,458$ & 482 & 59 & 0.007 & 5.5 \\
\hline & & Belly River & 308,925 & $5,456,143$ & 510 & 56 & 0.004 & 5.5 \\
\hline
\end{tabular}

\begin{tabular}{|c|c|c|c|c|c|c|c|c|}
\hline Region & Q2-Range & Reach Name & $\begin{array}{l}\text { Easting } \\
\text { UTM Zone } 12 \\
\text { NAD83 }\end{array}$ & $\begin{array}{l}\text { Northing } \\
\text { UTM Zone } 12 \\
\text { NAD83 }\end{array}$ & $\begin{array}{l}\text { Drainage } \\
\text { Area } \\
\left(\mathrm{km}^{2}\right)\end{array}$ & $\begin{array}{l}\text { GIS } \\
\text { Estimated } \\
\text { Q2 }\left(\mathrm{m}^{3} / \mathrm{s}\right)\end{array}$ & $\begin{array}{l}\text { GIS } \\
\text { Estimated } \\
\text { Reach } \\
\text { Slope }\end{array}$ & $\begin{array}{l}\text { Nominal } \\
\text { Mean } \\
\text { Annual } \\
\text { Flow } \\
\left(\mathrm{m}^{3} / \mathrm{s}\right)\end{array}$ \\
\hline \multirow[t]{3}{*}{ N6 } & Low & Rosebud River & 305,215 & $5,706,346$ & 504 & 7 & 0.002 & 2.5 \\
\hline & & Lonepine Creek & 313,649 & $5,725,185$ & 578 & 8 & 0.002 & 2.5 \\
\hline & & Threehills Creek & 333,743 & $5,743,206$ & 538 & 8 & 0.002 & 2.5 \\
\hline
\end{tabular}


Figure 4.3

Locations of Selected Sites for Field Component 2

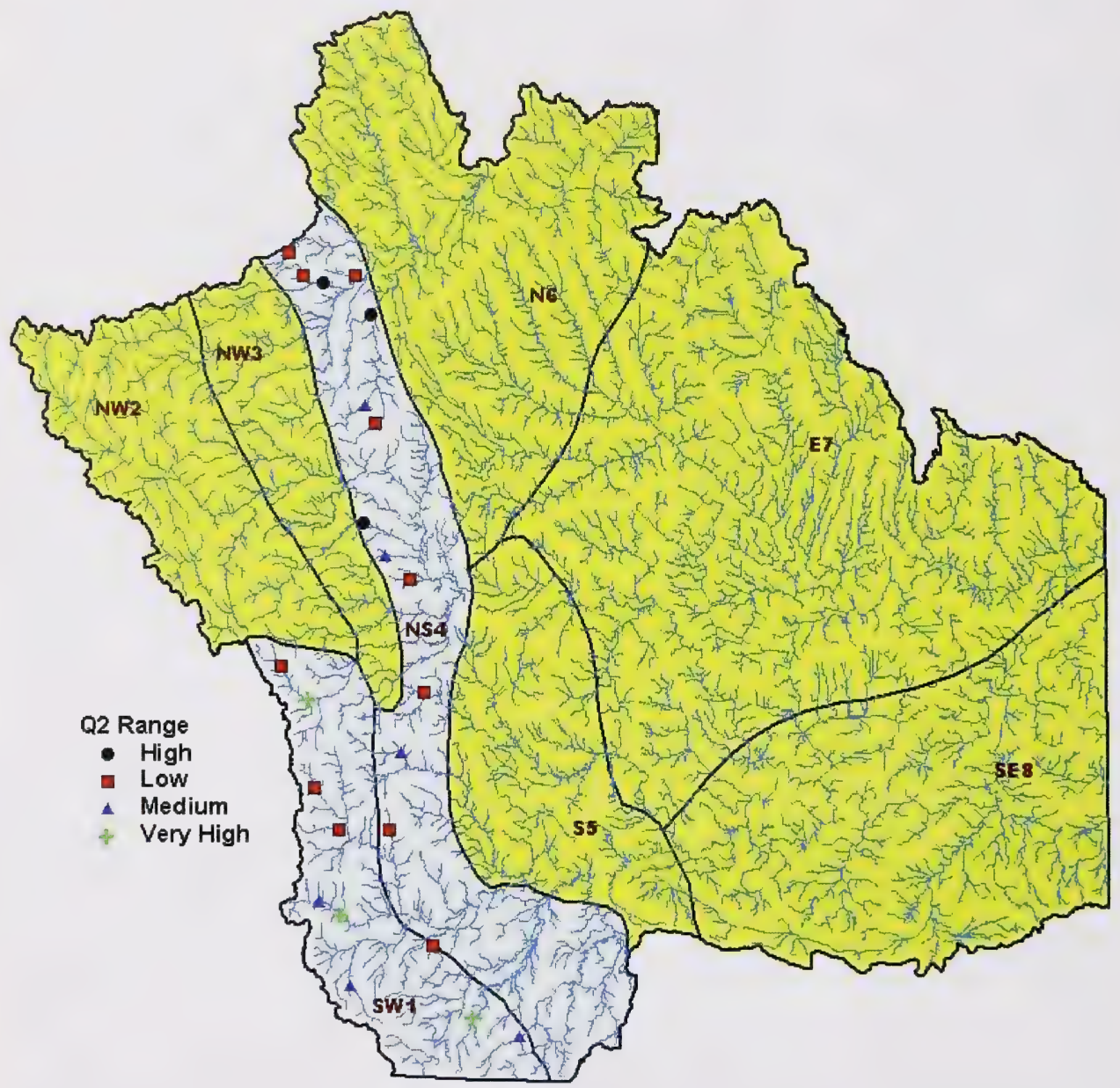

\subsubsection{Field Component 3}

Ideally, Field Component 3 should cover all of the eight hydrologic-geomorphic regions. However, only two regions, the Foothills (NS4) and the Prairies (N6), were selected in consideration of the budget and time constraints and limitations. 
Ideally, about 30 stream reaches in each region would be sampled, based on the need to identify incremental changes in stream hydraulics in the order of $10 \%$ to $20 \%$ over the range of possible Q2's for a given Slp. Most of the interest in transfer of IFNs (hence, hydraulics) under this Project is for watersheds with drainage areas (DA) ranging from $10 \mathrm{~km}^{2}$ to about $2,000 \mathrm{~km}^{2}$. Since Q2 is a function of DA, the number of reaches needed to identify the incremental changes can be calculated on the basis of DA incrementally increasing by $20 \%$. This suggests a number of 30 reaches for examination to cover the entire range of drainage areas in each region.

Only 18 sites could be identified in region NS4 because of the similarity in range criteria between Q2 and Slp (Golder 2002). Only 17 of these sites were actually surveyed due to field sampling limitations (e.g., refusal of land access, presence of beaver dams), with 4 of the sites being replaced after the original field visit and 1 site dropped and not replaced (Reach 03) since a suitable replacement could not be identified. The final surveyed sites for region NS4 are listed in Table 4.3 and are shown in Figure 4.4.

In region N6, where the ranges of Slp and Q2 are small, it was not possible to obtain more than eight sites for a range of Q2 for a given Slp. The site selection for Region N6 was then made so that the variation of reach hydraulics could be assessed for incremental changes in both Q2 and Slp. The selected sites in region N6 are listed in Table 4.4 and are shown in Figure 4.5.

Table 4.3

Sites Selected in Region NS4 for Field Component 3

\begin{tabular}{|c|c|c|c|c|c|c|c|}
\hline Region & Q2-Range & Reach Name & $\begin{array}{l}\text { Easting } \\
\text { UTM Zone } 12 \\
\text { NAD83 }\end{array}$ & $\begin{array}{l}\text { Northing } \\
\text { UTM Zone } 12 \\
\text { NAD83 }\end{array}$ & $\begin{array}{l}\text { Drainage } \\
\text { Area } \\
\left(\mathrm{km}^{2}\right)\end{array}$ & \begin{tabular}{|l} 
GIS \\
Estimated \\
Q2 $\left(\mathrm{m}^{3} / \mathrm{s}\right)$
\end{tabular} & $\begin{array}{l}\text { GIS } \\
\text { Estimated } \\
\text { Reach Slope }\end{array}$ \\
\hline \multirow[t]{17}{*}{ NS4 } & Entire & Reach01 & 263,988 & $5,737,185$ & 29 & 4 & 0.0051 \\
\hline & & Reach02 & 246,145 & $5,745,562$ & 41 & 5 & 0.0048 \\
\hline & & Reach19 & 255,301 & $5,763,206$ & 89 & 9 & 0.0042 \\
\hline & & Reach20 & 268,670 & $5,701,505$ & 112 & 11 & 0.0040 \\
\hline & & Reach06 & 349,084 & $5,461,253$ & 138 & 13 & 0.0044 \\
\hline & & Reach07 & 271,811 & $5,706,421$ & 182 & 16 & 0.0047 \\
\hline & & Reach08 & 242,800 & $5,777,467$ & 194 & 17 & 0.0043 \\
\hline & & Reach09 & 275,686 & $5,679,847$ & 234 & 20 & 0.0048 \\
\hline & & Reach10 & 263,846 & $5,709,264$ & 287 & 24 & 0.0043 \\
\hline & & Reach21 & 267,663 & $5,715,067$ & 345 & 27 & 0.0048 \\
\hline & & Reach12 & 257,173 & $5,776,952$ & 389 & 30 & 0.0046 \\
\hline & & Reach22 & 326,711 & $5,475,392$ & 501 & 38 & 0.0050 \\
\hline & & Reach14 & 249,363 & $5,715,780$ & 625 & 45 & 0.0048 \\
\hline & & Reach15 & 293,954 & $5,556,715$ & 789 & 55 & 0.0052 \\
\hline & & Reach16 & 297,795 & $5,556,759$ & 917 & 62 & 0.0043 \\
\hline & & Reach17 & 270,782 & $5,523,039$ & 1415 & 88 & 0.0046 \\
\hline & & Reach18 & 283,954 & $5,602,178$ & 1875 & 111 & 0.0044 \\
\hline
\end{tabular}


Figure 4.4

Locations of Selected Sites in Region NS4 for Field Component 3

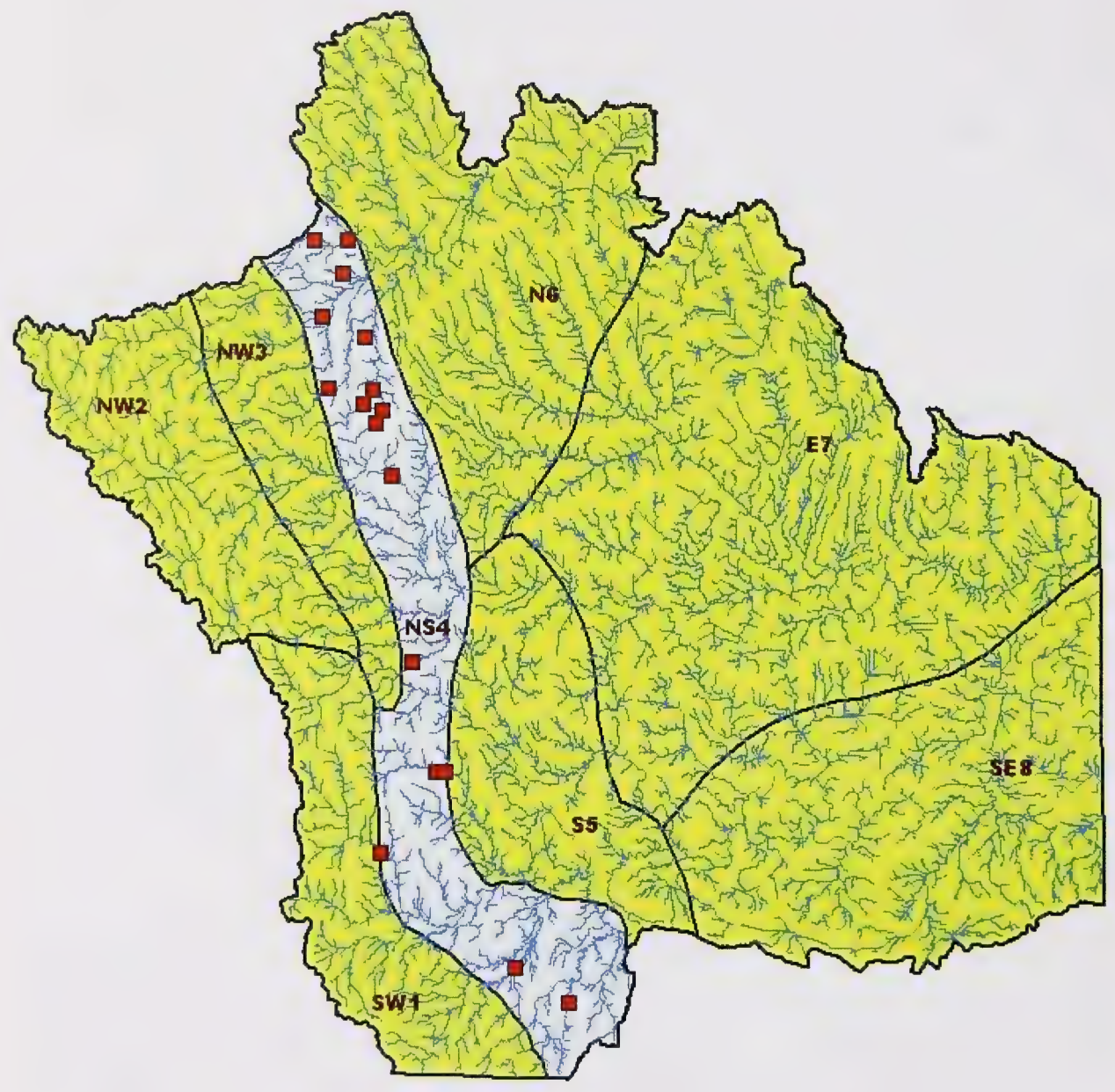

- study site locations. 
Table 4.4

Sites Selected in Region N6 for Field Component 3

\begin{tabular}{|c|c|c|c|c|c|c|c|}
\hline Region & Q2-Range & Reach Name & $\begin{array}{l}\text { Easting } \\
\text { UTM Zone } 12 \\
\text { NAD83 }\end{array}$ & $\begin{array}{l}\text { Northing } \\
\text { UTM Zone } 12 \\
\text { NAD83 }\end{array}$ & $\begin{array}{l}\text { Drainage } \\
\text { Area } \\
\left(\mathrm{km}^{2}\right)\end{array}$ & $\begin{array}{l}\text { GIS } \\
\text { Estimated } \\
\text { Q2 }\left(\mathrm{m}^{3} / \mathrm{s}\right)\end{array}$ & $\begin{array}{l}\text { GIS Estimated } \\
\text { Reach Slope }\end{array}$ \\
\hline \multirow[t]{19}{*}{ N6 } & Entire & Reach02 & 328,103 & $5,756,680$ & 331 & 4 & 0.0013 \\
\hline & & Reach04 & 332,637 & $5,748,311$ & 466 & 6 & 0.0013 \\
\hline & & Reach05 & 333,239 & $5,743,851$ & 495 & 7 & 0.0013 \\
\hline & & Reach06 & 347,039 & $5,749,198$ & 551 & 8 & 0.0013 \\
\hline & & Reach07 & 322,181 & $5,726,887$ & 593 & 9 & 0.0010 \\
\hline & & Reach08 & 350,765 & $5,744,069$ & 663 & 10 & 0.0024 \\
\hline & & Reach09 & 309,081 & $5,701,805$ & 745 & 12 & 0.0017 \\
\hline & & Reach10 & 353,210 & $5,737,822$ & 782 & 12 & 0.0010 \\
\hline & & Reach11 & 355,486 & $5,729,794$ & 888 & 14 & 0.0013 \\
\hline & & Reach12 & 343,282 & $5,722,575$ & 936 & 15 & 0.0023 \\
\hline & & Reach13 & 356,814 & $5,724,932$ & 947 & 16 & 0.0029 \\
\hline & & Reach14 & 285,420 & $5,828,933$ & 992 & 17 & 0.0014 \\
\hline & & Reach15 & 350,489 & $5,716,961$ & 1039 & 18 & 0.0026 \\
\hline & & Reach16 & 321,692 & $5,689,171$ & 1376 & 25 & 0.0010 \\
\hline & & Reach17 & 325,934 & $5,688,756$ & 1427 & 26 & 0.0013 \\
\hline & & Reach18 & 330,780 & $5,689,076$ & 1637 & 31 & 0.0010 \\
\hline & & Reach19 & 328,705 & $5,715,745$ & 1817 & 36 & 0.0018 \\
\hline & & Reach20 & 330,972 & $5,714,566$ & 1850 & 36 & 0.0025 \\
\hline & & Reach21 & 343,894 & $5,687,267$ & 1867 & 37 & 0.0030 \\
\hline
\end{tabular}

Figure 4.5

Locations of Selected Sites in Region N6 for Field Component 3

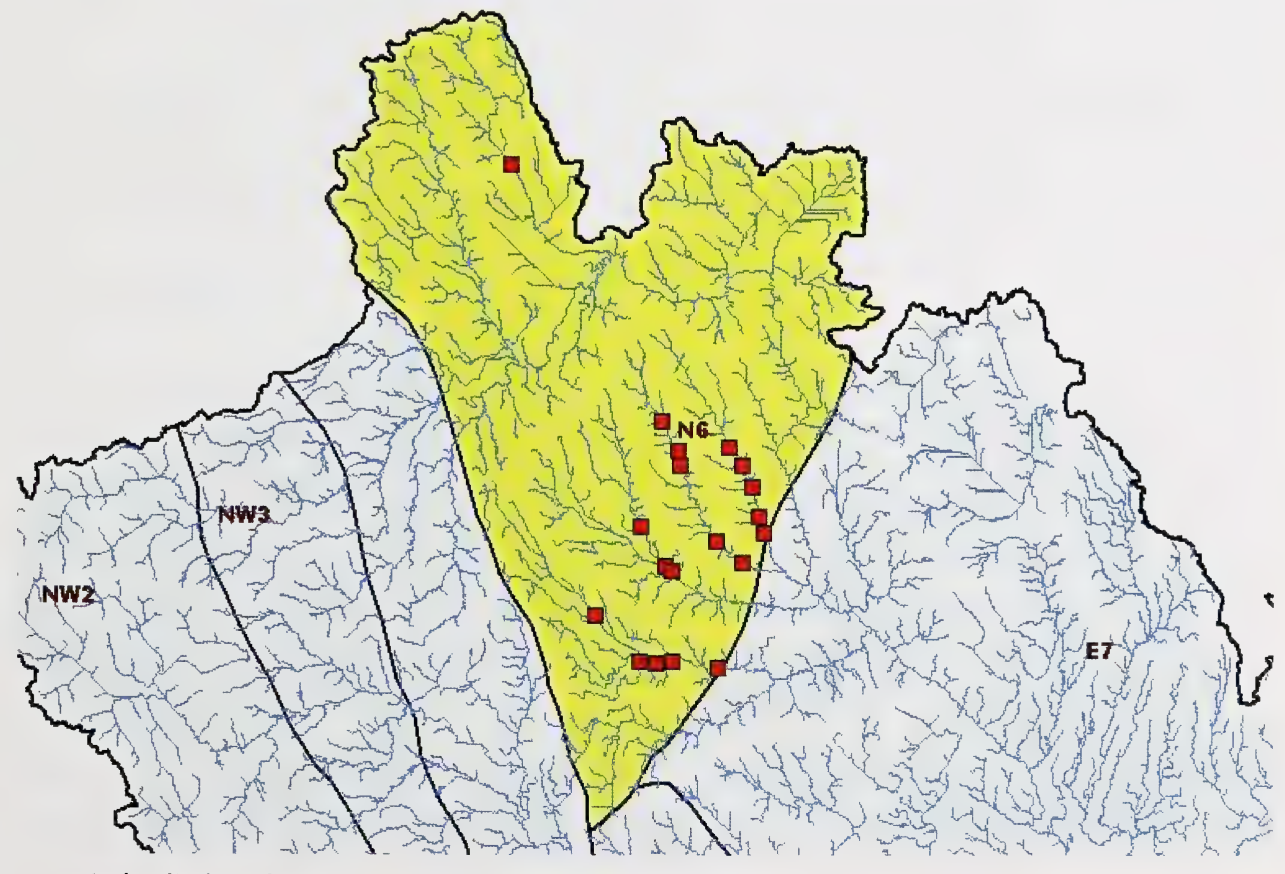

- study site locations. 


\subsection{Field Data Collection Protocols}

A rapid data collection procedure was required for the field data collection at each site to ensure that the field work could be undertaken within the constraints of available budget and time. This rapid procedure was a result of a compromise between the technical requirements and the abovementioned constraints. The design of the field data collection protocols reflected this compromise. Detailed field data collection protocols are provided in Golder (2002) and the Specific Work Instructions for the field data collection procedures are provided in Appendix VIII.

The fieldwork conducted at each selected site or stream reach generally consisted of the following activities:

- Selection at least three (and up to six) transects representative of the habitat types in a stream reach. The intent was to have at least one transect for each of the most common habitat types in the stream reach. The field crew noted the relative abundance or percentage of each habitat type in the stream reach. The analysis of the field data accounted for the variable hydraulic conditions in pools, riffles, rapids and runs within each stream reach.

- Measurement of the cell flow velocities, cell water depths, and surface water widths at one discharge for each of the three to six transects at each of the surveyed stream reaches. Stream reaches with very low flows encountered during the survey were not sampled. During the flow measurement, the average particle size of substrate in each cell was noted. The number of cells selected for the flow velocity and depth measurements were such that the cell widths were constants, the flow in each cell contributed not more than $5 \%$ to the total cross-sectional discharge, and all the changes in habitat, including substrate and stream bottom geometry were captured.

- Measurement of the geometric data for each stream channel cross section up to the tops of the channel banks. These cross-sectional data as well as the water levels associated with the measured discharges for all transects within a stream reach, were tied to a common benchmark.

\subsection{Collected Field Data}

The collected field data are provided separately on CD-ROM. 


\section{FIELD DATA ANALYSIS}

\section{$5.1 \quad$ Scope}

The field investigations resulted in collection of hydrologic, hydraulic and geomorphic data for each of the selected stream reaches. The hydraulic information at each stream reach was collected for one discharge condition encountered in the field. However, the validation of the stream classification method required an examination of a range of hydraulic conditions associated with low to mean stream flows. In addition, determining hydraulic similarity between two comparable stream reaches required a comparison of the hydraulic parameters (e.g., flow depths and velocities) at the same discharge, which could be different from the measured discharges encountered in the field.

Therefore, the field data needed to be analyzed and relevant hydraulic modelling analysis needed to be conducted. The purpose of the hydraulic modelling analysis was to calculate or estimate stream hydraulic parameters (i.e., flow depths and velocities) associated with various discharges based on one set of measured hydraulic data associated with a measured discharge at each stream reach. The modelling analysis involved calculation of water levels, cross-sectional average flow depths and velocities, and lateral distributions of flow depths and velocities (or cell depths and velocities).

\subsection{Methods}

Two modelling approaches were considered and evaluated for analyzing the hydraulic conditions at the surveyed sites based on the collected field data. One is the HEC-RAS model and the other is a customized modelling approach based on well-established and applicable hydraulic equations and empirical relationships. The latter approach was adopted for the final analysis in this study, in consideration of the limitations of the rapid data collection procedure and the need to maximize the accuracy and efficiency of the modelling analysis.

Appendix I provides a detailed description of the modelling method for analyzing the hydraulics. The key steps of the hydraulic analysis are summarized below: 
1. Calculate the water levels and cross-sectional hydraulic parameters associated with various discharges for each transect using a modelling relationship and based on the available measurements at the transect;

2. Calculate the cell flow depths at each transect based on the surveyed cross-sectional geometry and the water levels associated with the various discharges calculated in Step 1;

3. Calculate the cell flow velocities at each transect associated with various discharges based on a hydraulic model for characterizing the lateral variation of flow velocities at a stream cross section, which is calibrated based on the measured cell flow velocities associated with one measured discharge at the transect;

4. Calculate reach-averaged cell flow velocities and depths based on the calculated cell flow velocities and depths at the three to six transects of a stream reach, which are weighted by the percentages of the habitat types along the stream reach and by cell widths; and,

5. Calculate reach-averaged distributions of cell flow velocities and depths based on the calculated distributions of cell flow velocities and depths at the three to six transects of a stream reach, weighted by the percentages of the habitat types along the stream reach and by cell widths. The reach-averaged distributions of cell flow velocities and depths are expressed as percentages of occurrence of flow velocity ranges or bins (e.g., between 0 and $0.2 \mathrm{~m} / \mathrm{s}, 0.2$ and $0.4 \mathrm{~m} / \mathrm{s}$, etc.) and flow depth ranges or bins (e.g., between 0 and $0.1 \mathrm{~m}, 0.1$ and $0.2 \mathrm{~m}$, etc.) within a stream reach.

\subsection{Results}

\subsubsection{Field Component 1}

\section{Results of the Hydraulic Analysis}

The data collected under Field Component 1 were analyzed to test the hypothesis that the streams within a given hydrologic-geomorphic region and with similar Q2 (2-year flood peak flow) and Slp (reach-averaged channel bed slope) have similar hydraulics. A sample size of eight sites in region NS4 is less than the estimated minimum of 11 sites as discussed in Section 4.2. 
The calculated reach-averaged cell flow velocities and depths at the eight stream reaches surveyed are presented in Table 5.1 for three $\left(0.3,0.5\right.$ and $\left.1.0 \mathrm{~m}^{3} / \mathrm{s}\right)$ of the several discharges analyzed. The percentages of cell flow velocities and depths within the pre-specified bin classes at one of the three discharges $\left(1.0 \mathrm{~m}^{3} / \mathrm{s}\right)$ are presented in Tables 5.2 and 5.3. The ranges of cell velocities and depths reported in the tables have been truncated for presentation purposes. Detailed results are provided separately on CD-ROM. The estimated mean annual flow at the eight sites is $1.0 \mathrm{~m}^{3} / \mathrm{s}$. This nominal value of mean annual flow, which actually varies to some degree within a region and from watershed to watershed, is used as an index for comparison with other sets of streams and for selecting flows for hydraulic simulation. Appendix II provides the percentages of cell velocities and depths within pre-specified bin classes for the other two discharges in tabular format. Appendix III presents these the percentages on bar charts, together with the site photos and their locations in region NS4. Appendix VI provides the calculation details using an example stream.

Table 5.1

Reach-Averaged Cell Flow Velocities (m/s) and Depths (m) for the Eight Sites in Region NS4 (Field Component 1)

\begin{tabular}{|c|c|c|c|c|c|c|c|}
\hline \multirow[b]{3}{*}{$\begin{array}{l}\text { Stream } \\
\text { Name }\end{array}$} & \multirow[b]{3}{*}{$\begin{array}{c}\text { Sub- } \\
\text { division } \\
\text { of Region }\end{array}$} & \multicolumn{6}{|c|}{ Calculated Hydraulic Parameters for Three Simulated Discharges $\left(\mathrm{m}^{3} / \mathrm{s}\right)$ (Q2 Range: Low) } \\
\hline & & \multicolumn{2}{|c|}{$0.3 \mathrm{~m}^{3} / \mathrm{s}$} & \multicolumn{2}{|c|}{$0.5 \mathrm{~m}^{3} / \mathrm{s}$} & \multicolumn{2}{|c|}{$1.0 \mathrm{~m}^{3} / \mathrm{s}$} \\
\hline & & $\begin{array}{c}\text { Reach- } \\
\text { Averaged Cell } \\
\text { Flow Velocity }\end{array}$ & $\begin{array}{l}\text { Reach- } \\
\text { Averaged Cell } \\
\text { Flow Depth }\end{array}$ & $\begin{array}{c}\text { Reach- } \\
\text { Averaged Cell } \\
\text { Flow Velocity }\end{array}$ & $\begin{array}{l}\text { Reach- } \\
\text { Averaged Cell } \\
\text { Flow Depth }\end{array}$ & $\begin{array}{c}\text { Reach- } \\
\text { Averaged Cell } \\
\text { Flow Velocity }\end{array}$ & $\begin{array}{l}\text { Reach- } \\
\text { Averaged Cell } \\
\text { Flow Depth }\end{array}$ \\
\hline Raven River & North & 0.18 & 0.25 & 0.25 & 0.32 & 0.34 & 0.44 \\
\hline $\begin{array}{l}\text { East Stony } \\
\text { Creek }\end{array}$ & North & 0.20 & 0.23 & 0.26 & 0.29 & 0.31 & 0.39 \\
\hline $\begin{array}{l}\text { Beaverdam } \\
\text { Creek }\end{array}$ & North & 0.37 & 0.34 & 0.45 & 0.46 & 0.51 & 0.59 \\
\hline $\begin{array}{l}\text { Schrader } \\
\text { Creek }\end{array}$ & North & 0.13 & 0.49 & 0.13 & 0.44 & 0.15 & 0.53 \\
\hline Pine Creek & South & 0.13 & 0.38 & 0.16 & 0.47 & 0.19 & 0.60 \\
\hline $\begin{array}{l}\text { Mosquito } \\
\text { Creek }\end{array}$ & South & 0.12 & 0.40 & 0.15 & 0.45 & 0.18 & 0.55 \\
\hline Callum Creek & South & 0.12 & 0.55 & 0.15 & 0.67 & 0.16 & 0.79 \\
\hline $\begin{array}{l}\text { Indianfarm } \\
\text { Creek }\end{array}$ & South & 0.13 & 0.55 & 0.13 & 0.62 & 0.15 & 0.75 \\
\hline
\end{tabular}


Table 5.2

Percent Distribution of Cell Flow Velocities $(\mathrm{m} / \mathrm{s})$ at One Discharge in Region NS4

\begin{tabular}{|c|c|c|c|c|c|c|c|c|c|c|c|c|}
\hline \multirow[b]{2}{*}{ Stream Name } & \multirow{2}{*}{$\begin{array}{c}\text { Region - Q2 } \\
\text { Range (Sub- } \\
\text { division) }\end{array}$} & \multirow{2}{*}{$\begin{array}{c}\text { Discharge } \\
\left(\mathrm{m}^{3} / \mathrm{s}\right)\end{array}$} & \multicolumn{10}{|c|}{ Percentage of Cell Flow Velocity $(\mathrm{m} / \mathrm{s})$ within each Bin Class } \\
\hline & & & 0.1 & 0.2 & 0.3 & 0.4 & 0.5 & 0.6 & 0.7 & 0.8 & 0.9 & 1 \\
\hline Raven River & $\begin{array}{l}\text { NS4 Low } \\
\text { (North) }\end{array}$ & 1.0 & 28 & 8 & 8 & 11 & 20 & 11 & 5 & 3 & 0 & 1 \\
\hline $\begin{array}{l}\text { East Stony } \\
\text { Creek }\end{array}$ & $\begin{array}{l}\text { NS4 Low } \\
\text { (North) }\end{array}$ & 1.0 & 45 & 19 & 36 & 0 & 0 & 0 & 0 & 0 & 0 & 0 \\
\hline $\begin{array}{l}\text { Beaverdam } \\
\text { Creek }\end{array}$ & $\begin{array}{l}\text { NS4 Low } \\
\text { (North) }\end{array}$ & 1.0 & 27 & 2 & 2 & 5 & 11 & 18 & 11 & 18 & 0 & 0 \\
\hline $\begin{array}{l}\text { Schrader } \\
\text { Creek }\end{array}$ & $\begin{array}{l}\text { NS4 Low } \\
\text { (North) }\end{array}$ & 1.0 & 68 & 19 & 5 & 3 & 4 & 0 & 0 & 0 & 0 & 0 \\
\hline Pine Creek & $\begin{array}{l}\text { NS4 Low } \\
\text { (South) }\end{array}$ & 1.0 & 60 & 15 & 5 & 7 & 7 & 0 & 6 & 0 & 0 & 0 \\
\hline $\begin{array}{l}\text { Mosquito } \\
\text { Creek }\end{array}$ & $\begin{array}{l}\text { NS4 Low } \\
\text { (South) }\end{array}$ & 1.0 & 49 & 24 & 6 & 8 & 12 & 0 & 0 & 0 & 0 & 0 \\
\hline Callum Creek & $\begin{array}{l}\text { NS4 Low } \\
\text { (South) }\end{array}$ & 1.0 & 53 & 9 & 19 & 6 & 12 & 2 & 0 & 0 & 0 & 0 \\
\hline $\begin{array}{l}\text { Indianfarm } \\
\text { Creek }\end{array}$ & $\begin{array}{l}\text { NS4 Low } \\
\text { (South) }\end{array}$ & 1.0 & 54 & 9 & 14 & 12 & 7 & 2 & 2 & 0 & 0 & 0 \\
\hline
\end{tabular}

Table 5.3

Percentage Distributions of Cell Flow Depths (m) at One Discharge in Region NS4

\begin{tabular}{|c|c|c|c|c|c|c|c|c|c|c|c|c|}
\hline \multirow[b]{2}{*}{ Stream Name } & \multirow{2}{*}{$\begin{array}{c}\text { Region - Q2 } \\
\text { Range (Sub- } \\
\text { division) }\end{array}$} & \multirow{2}{*}{$\begin{array}{c}\text { Discharge } \\
\left(\mathrm{m}^{3} / \mathrm{s}\right)\end{array}$} & \multicolumn{10}{|c|}{ Percentage of Cell Flow Depth $(m)$ within each Bin Class } \\
\hline & & & 0.1 & 0.2 & 0.3 & 0.4 & 0.5 & 0.6 & 0.7 & 0.8 & 0.9 & 1 \\
\hline Raven River & $\begin{array}{l}\text { NS4 Low } \\
\text { (North) }\end{array}$ & 1.0 & 4 & 7 & 10 & 13 & 30 & 12 & 20 & 1 & 1 & 2 \\
\hline $\begin{array}{l}\text { East Stony } \\
\text { Creek }\end{array}$ & $\begin{array}{l}\text { NS4 Low } \\
\text { (North) }\end{array}$ & 1.0 & 32 & 40 & 27 & 0 & 0 & 0 & 0 & 0 & 0 & 0 \\
\hline $\begin{array}{l}\text { Beaverdam } \\
\text { Creek }\end{array}$ & $\begin{array}{l}\text { NS4 Low } \\
\text { (North) }\end{array}$ & 1.0 & 12 & 1 & 2 & 13 & 5 & 4 & 6 & 23 & 24 & 6 \\
\hline $\begin{array}{l}\text { Schrader } \\
\text { Creek }\end{array}$ & $\begin{array}{l}\text { NS4 Low } \\
\text { (North) }\end{array}$ & 1.0 & 12 & 12 & 12 & 11 & 11 & 9 & 3 & 5 & 4 & 3 \\
\hline Pine Creek & $\begin{array}{l}\text { NS4 Low } \\
\text { (South) }\end{array}$ & 1.0 & 10 & 3 & 12 & 10 & 10 & 11 & 3 & 12 & 6 & 5 \\
\hline $\begin{array}{l}\text { Mosquito } \\
\text { Creek }\end{array}$ & $\begin{array}{l}\text { NS4 Low } \\
\text { (South) }\end{array}$ & 1.0 & 8 & 11 & 9 & 12 & 14 & 5 & 7 & 5 & 5 & 3 \\
\hline Callum Creek & $\begin{array}{l}\text { NS4 Low } \\
\text { (South) }\end{array}$ & 1.0 & 5 & 14 & 7 & 4 & 5 & 6 & 9 & 6 & 5 & 4 \\
\hline $\begin{array}{l}\text { Indianfarm } \\
\text { Creek }\end{array}$ & $\begin{array}{l}\text { NS4 Low } \\
\text { (South) }\end{array}$ & 1.0 & 5 & 12 & 9 & 11 & 6 & 7 & 3 & 6 & 4 & 12 \\
\hline
\end{tabular}




\section{Analysis of the Results of the Reach-Averaged Cell Flow Velocities and Depths}

An examination of the site photos indicates that there are noticeable morphological similarities and differences among the eight sites. In particular, the two sites located in the most northern part of region NS4 seem to be less incised and have greater widths than those in the southern half. The four sites in the southern part of NS4 are very similar to one another based on the visual inspection.

This visual assessment was further corroborated when the reach-averaged cell flow velocities and depths are compared. The four sites in the lower half of NS4 (henceforth referred to as NS4 South) are very similar to one another. The four sites in the northern half of NS4 (henceforth referred to as NS4 North), except the Schrader Creek site, have very different reach-averaged cell flow velocities and depths from the sites in NS4 South. The Raven River and East Stony sites in NS4 North are fairly comparable. The Beaverdam Creek site in NS4 North is likely an outlier. These comparisons suggest that hydrologic regimes in NS4 North and South are different and there should be differences in Q2 between the north and south sites.

The initial division of the SSRB into hydrologic-geomorphic regions was based on a number of factors including the ability to develop regression equations based on the data at the gauged watersheds. For region NS4, flood flow data were available at the 12 gauging stations for predicting Q2, which was considered adequate for development of the regression equations. Further sub-division of NS4 into two regions would have resulted in one sub-region having only five sets of data to predict Q2, which would have resulted in a regression equation with a much larger standard error of estimates. However, the results of the field data analysis support a division of region NS4 into two, although the statistical basis for the division cannot be supported with the presently available data (lack of gauged watersheds). The physical observations suggest that a division of NS4 is supportable.

With this sub-division of region NS4, the number of sites available for the statistical testing of hydraulic similarity has been reduced to four from the eight sites surveyed. This sample size is considered inadequate for any but the most simple form of statistical analysis. Table 5.1 indicates that for region NS4 South, the reach-averaged flow velocity at a particular site is generally within $10 \%$ of the mean flow velocity of the four sites, and the reach-averaged flow depths are generally within $20 \%$ of the sample mean depth. 
The following factors affect the accuracy of the computed reach-averaged cell flow velocity and depth at each transect:

- The accuracy of the discharge measurement is about $\pm 10 \%$.

- Errors were introduced by using a hydraulic model calibrated on one set of hydraulic information associated with a single discharge at each site for simulating a wide range of discharges. The errors could be quite large if the simulated discharges were significantly different from the measured discharge.

- A limited number of transects (between three and six) were used to represent the complex habitat types or variation of hydraulic conditions within each stream reach.

The errors introduced by the above factors can be as large as $30 \%$, which are comparable to the differences of 10 to $20 \%$ between the sample means and the reach-averaged hydraulic parameters at the four NS4 South sites. These simple statistical comparisons, while not tested rigorously because of the sample size limitation, support the hypothesis of hydraulic similarity among the four sites. However, surveys of more sites are necessary to validate the hypothesis.

Two of the four NS4 North sites, the Raven River and East Stony Creek sites, have similar reachaveraged cell flow velocities and depths for the three discharges listed in Table 5.1. The differences from the means of the two sites are within $10 \%$. The Beaverdam Creek site can be treated as an outlier, since its reach-averaged cell flow velocities can be up to $100 \%$ different from the means of the Raven River and East Stony Creek sites, and its reach-averaged cell flow depths can be up to $50 \%$ different from the means of the other two sites. The Schrader Creek site, displays similar reach-average hydraulic parameters as the four NS4 South sites, but its reachaveraged cell flow velocities and depths can be up to $50 \%$ different from the means of the Raven River and East Stony Creek sites.

\section{Analysis of the Results of the Reach-Averaged Distributions of Cell Flow Velocities and Depths}

The hypothesis of hydraulic similarity is further supported based on a visual inspection of the results of the reach-averaged distributions of cell flow velocities and depths (Tables 5.2 and 5.3, and Appendix II and III). These results show that the stream reaches from NS4 South display very similar cell velocity and depth distributions, especially within the bin classes with the 
highest percentages of occurrence. The ranges over which the cell flow velocities and depths occur are also generally similar among the NS4 South sites. The similarity, judged based on visual inspection but not tested rigorously using any statistical method, seems to occur over a range of simulated discharges.

This observation of similarity also applies to the Raven River and East Stony Creek sites in NS4 North. However, the other two sites, the Beaver Dam and Schrader Creek sites, display relatively large differences from the Raven River and East Stony Creek sites. It is worth noting that the distributions of reach-averaged cell flow velocities and depths at the Schrader Creek are similar to the four NS4 South sites.

\section{Summary of Results}

Considering the limited data sets available and the inherent errors associated with the field data collection and the hydraulic analysis, the results from the hydraulic analysis based on the Component 1 data reasonably support the hypothesis that the streams of similar Q2 and Slp within a given region (NS4 South or NS4 South) have similar hydraulics. Based on the reachaveraged hydraulic parameters, the deviation from the same hydraulic condition is within $\pm 20 \%$, $100 \%$ of the time for the four NS4 South sites, and the deviation from the same hydraulic condition is within $\pm 10 \%, 50 \%$ of the time; $\pm 50 \%, 75 \%$ of the time or $\pm 100 \%, 100 \%$ of the time for the four NS4 North sites. Notwithstanding these results, more sites need to be surveyed for a rigorous validation of the similarity hypothesis.

\subsubsection{Field Component 2}

\section{Analysis of the Results of the Reach-Averaged Cell Flow Velocities and Depths}

Data from two sets (medium and high range of Q2) of three sites were available for this analysis in region NS4 (Foothills). Table 5.4 presents the results of the hydraulic analysis in consideration of the need to divide the region into NS4 North and South. The results show that, wherever there are at least two sites in the same region (NS4 North or South), the reach-averaged cell flow velocities and depths are within 10 to $30 \%$ of the sample means. This is consistent with the results obtained for Field Component 1. 
Table 5.4

Reach-Averaged Cell Flow Velocities $(\mathrm{m} / \mathrm{s})$ and Depths $(\mathrm{m})$ at Three Simulated Discharges for Two Q2 Different Ranges in Region NS4

\begin{tabular}{|c|c|c|c|c|c|c|c|}
\hline \multirow[b]{3}{*}{$\begin{array}{l}\text { Stream } \\
\text { Name }\end{array}$} & \multirow[b]{3}{*}{$\begin{array}{c}\text { Region - Q2 } \\
\text { Range (Sub- } \\
\text { division) }\end{array}$} & \multicolumn{6}{|c|}{ Calculated Hydraulic Parameters for Three Simulated Discharges $\left(\mathrm{m}^{3} / \mathrm{s}\right)$} \\
\hline & & \multicolumn{2}{|c|}{$1.25 \mathrm{~m}^{3} / \mathrm{s}$} & \multicolumn{2}{|c|}{$2.5 \mathrm{~m}^{3} / \mathrm{s}$} & \multicolumn{2}{|c|}{$3.75 \mathrm{~m}^{3} / \mathrm{s}$} \\
\hline & & $\begin{array}{c}\text { Reach- } \\
\text { Averaged Cell } \\
\text { Flow Velocity }\end{array}$ & $\begin{array}{l}\text { Reach- } \\
\text { Averaged Cell } \\
\text { Flow Depth }\end{array}$ & $\begin{array}{l}\text { Reach- } \\
\text { Averaged Cell } \\
\text { Flow Velocity }\end{array}$ & $\begin{array}{l}\text { Reach- } \\
\text { Averaged Cell } \\
\text { Flow Depth }\end{array}$ & $\begin{array}{l}\text { Reach- } \\
\text { Averaged Cell } \\
\text { Flow Velocity }\end{array}$ & $\begin{array}{l}\text { Reach- } \\
\text { Averaged Cel } \\
\text { Flow Depth }\end{array}$ \\
\hline $\begin{array}{l}\text { Dogpound } \\
\text { Creek }\end{array}$ & $\begin{array}{l}\text { NS4 Medium } \\
\text { (North) }\end{array}$ & 0.27 & 0.73 & 0.30 & 0.86 & 0.34 & 0.96 \\
\hline Fish Creek & $\begin{array}{l}\text { NS4 Medium } \\
\text { (South) }\end{array}$ & 0.21 & 0.39 & 0.30 & 0.53 & 0.35 & 0.61 \\
\hline $\begin{array}{l}\text { Willow } \\
\text { Creek }\end{array}$ & $\begin{array}{l}\text { NS4 Medium } \\
\text { (South) }\end{array}$ & 0.23 & 0.50 & 0.30 & 0.67 & 0.34 & 0.78 \\
\hline
\end{tabular}

\begin{tabular}{|c|c|c|c|c|c|c|c|}
\hline \multirow[b]{3}{*}{$\begin{array}{l}\text { Stream } \\
\text { Name }\end{array}$} & \multirow[b]{3}{*}{$\begin{array}{c}\text { Region - Q2 } \\
\text { Range (Sub- } \\
\text { division) }\end{array}$} & \multicolumn{6}{|c|}{ Calculated Hydraulic Parameters for Three Simulated Discharges $\left(\mathrm{m}^{3} / \mathrm{s}\right)$} \\
\hline & & \multicolumn{2}{|c|}{$4.25 \mathrm{~m}^{3} / \mathrm{s}$} & \multicolumn{2}{|c|}{$8.5 \mathrm{~m}^{3} / \mathrm{s}$} & \multicolumn{2}{|c|}{$12.75 \mathrm{~m}^{3} / \mathrm{s}$} \\
\hline & & $\begin{array}{c}\text { Reach- } \\
\text { Averaged Cell } \\
\text { Flow Velocity }\end{array}$ & $\begin{array}{l}\text { Reach- } \\
\text { Averaged Cell } \\
\text { Flow Depth }\end{array}$ & $\begin{array}{c}\text { Reach- } \\
\text { Averaged Cell } \\
\text { Flow Velocity }\end{array}$ & $\begin{array}{c}\text { Reach- } \\
\text { Averaged Cell } \\
\text { Flow Depth }\end{array}$ & $\begin{array}{c}\text { Reach- } \\
\text { Averaged Cell } \\
\text { Flow Velocity }\end{array}$ & $\begin{array}{l}\text { Reach- } \\
\text { Averaged Cell } \\
\text { Flow Depth }\end{array}$ \\
\hline $\begin{array}{l}\text { James } \\
\text { River }\end{array}$ & $\begin{array}{l}\text { NS4 High } \\
\text { (North) }\end{array}$ & 0.48 & 0.27 & 0.68 & 0.38 & 0.82 & 0.46 \\
\hline $\begin{array}{l}\text { Little Red } \\
\text { Deer River }\end{array}$ & $\begin{array}{l}\text { NS4 High } \\
\text { (North) }\end{array}$ & 0.58 & 0.32 & 0.82 & 0.46 & 0.99 & 0.57 \\
\hline Elbow River & $\begin{array}{l}\text { NS4 High } \\
\text { (South) }\end{array}$ & 0.61 & 0.36 & 0.87 & 0.51 & 1.01 & 0.61 \\
\hline
\end{tabular}

Table 5.5 presents the results of three data sets (low, medium and very high range of Q2) of three sites in region SW1 (Mountains). It should be noted that sites within each given Q2 range are unique locations (i.e., Highwood River 'low' is a site distinct from Highwood River 'high'). The location of the site on the Highwood River representing the low Q2 range is further upstream and has a smaller drainage area relative to the Highwood River site representing the high Q2 range. Table 5.6 shows the results for the only data set (low range of Q2) of three sites in region N6 (Prairies). Detailed results are presented in the accompanying CD-ROM. 
Table 5.5

Reach-Averaged Cell Flow Velocities $(\mathrm{m} / \mathrm{s})$ and Depths $(\mathrm{m})$ at Three Simulated Discharges for Three Q2 Ranges in Region SW1

\begin{tabular}{|c|c|c|c|c|c|c|c|}
\hline \multirow[b]{3}{*}{ Stream Name } & \multirow[b]{3}{*}{ Q2 Range } & \multicolumn{6}{|c|}{ Calculated Hydraulic Parameters for Three Simulated Discharges $\left(\mathrm{m}^{3} / \mathrm{s}\right)$} \\
\hline & & \multicolumn{2}{|c|}{$1.0 \mathrm{~m}^{3} / \mathrm{s}$} & \multicolumn{2}{|c|}{$2.0 \mathrm{~m}^{3} / \mathrm{s}$} & \multicolumn{2}{|c|}{$3.0 \mathrm{~m}^{3} / \mathrm{s}$} \\
\hline & & $\begin{array}{c}\text { Reach- } \\
\text { Averaged Cell } \\
\text { Flow Velocity }\end{array}$ & $\begin{array}{l}\text { Reach- } \\
\text { Averaged Cell } \\
\text { Flow Depth }\end{array}$ & $\begin{array}{c}\text { Reach- } \\
\text { Averaged Cell } \\
\text { Flow Velocity }\end{array}$ & $\begin{array}{l}\text { Reach- } \\
\text { Averaged Cell } \\
\text { Flow Depth }\end{array}$ & $\begin{array}{c}\text { Reach- } \\
\text { Averaged Cell } \\
\text { Flow Velocity }\end{array}$ & $\begin{array}{l}\text { Reach- } \\
\text { Averaged Cell } \\
\text { Flow Depth }\end{array}$ \\
\hline Highwood River & Low & 0.41 & 0.23 & 0.59 & 0.31 & 0.66 & 0.37 \\
\hline Oldman River & Low & 0.36 & 0.17 & 0.51 & 0.24 & 0.62 & 0.29 \\
\hline Dutch Creek & Low & 0.40 & 0.21 & 0.59 & 0.31 & 0.72 & 0.39 \\
\hline
\end{tabular}

\begin{tabular}{|l|c|c|c|c|c|c|c|}
\hline \multirow{2}{*}{} & \multirow{2}{*}{ Stream Name } & \multicolumn{4}{|c|}{ Calculated Hydraulic Parameters for Three Simulated Discharges $\left(\mathbf{m}^{3} / \mathrm{s}\right)$} \\
\cline { 3 - 8 } & Q2 Range & $\begin{array}{c}\text { Reach- } \\
\text { Averaged Cell } \\
\text { Flow Velocity }\end{array}$ & $\begin{array}{c}\text { Reach- } \\
\text { Averaged Cell } \\
\text { Flow Depth }\end{array}$ & $\begin{array}{c}\text { Reach- } \\
\text { Averaged Cell } \\
\text { Flow Velocity }\end{array}$ & $\begin{array}{c}\text { Reach- } \\
\text { Averaged Cell } \\
\text { Flow Depth }\end{array}$ & $\begin{array}{c}\text { Reach- } \\
\text { Averaged Cell } \\
\text { Flow Velocity }\end{array}$ & $\begin{array}{c}\text { Reach- } \\
\text { Averaged Cell } \\
\text { Flow Depth }\end{array}$ \\
\hline Crowsnest River & Medium & 0.32 & 0.27 & 0.43 & 0.37 & 0.44 & 0.40 \\
\hline Castle River & Medium & 0.22 & 0.25 & 0.23 & 0.26 & 0.29 & 0.34 \\
\hline Lee Creek & Medium & 0.31 & 0.20 & 0.46 & 0.28 & 0.56 & 0.33 \\
\hline
\end{tabular}

\begin{tabular}{|c|c|c|c|c|c|c|c|}
\hline \multirow[b]{3}{*}{ Stream Name } & \multirow[b]{3}{*}{ Q2 Range } & \multicolumn{6}{|c|}{ Calculated Hydraulic Parameters for Three Simulated Discharges $\left(\mathrm{m}^{3} / \mathrm{s}\right)$} \\
\hline & & \multicolumn{2}{|c|}{$2.75 \mathrm{~m}^{3} / \mathrm{s}$} & \multicolumn{2}{|c|}{$5.5 \mathrm{~m}^{3} / \mathrm{s}$} & \multicolumn{2}{|c|}{$8.25 \mathrm{~m}^{3} / \mathrm{s}$} \\
\hline & & \begin{tabular}{c|} 
Reach- \\
Averaged Cell \\
Flow Velocity
\end{tabular} & \begin{tabular}{|c|} 
Reach- \\
Averaged Cell \\
Flow Depth \\
\end{tabular} & $\begin{array}{c}\text { Reach- } \\
\text { Averaged Cell } \\
\text { Flow Velocity }\end{array}$ & \begin{tabular}{|c|} 
Reach- \\
Averaged Cell \\
Flow Depth \\
\end{tabular} & \begin{tabular}{c|} 
Reach- \\
Averaged Cell \\
Flow Velocity
\end{tabular} & $\begin{array}{c}\text { Reach- } \\
\text { Averaged Cell } \\
\text { Flow Depth }\end{array}$ \\
\hline Highwood River & High & 0.37 & 0.41 & 0.47 & 0.54 & 0.54 & 0.63 \\
\hline Crowsnest River & High & 0.39 & 0.36 & 0.52 & 0.49 & 0.64 & 0.61 \\
\hline Belly River & High & 0.23 & 0.32 & 0.31 & 0.42 & 0.39 & 0.55 \\
\hline
\end{tabular}

Table 5.6

Reach-Averaged Cell Flow Velocities $(\mathrm{m} / \mathrm{s})$ and Depths $(\mathrm{m})$ at Three Simulated Discharges for One Q2 Range in Region N6

\begin{tabular}{|c|c|c|c|c|c|c|}
\hline \multirow[b]{3}{*}{ Stream Name } & \multicolumn{6}{|c|}{ Calculated Hydraulic Parameters for Three Simulated Discharges $\left(\mathrm{m}^{3} / \mathrm{s}\right)$ (Q2 Range: Low) } \\
\hline & \multicolumn{2}{|c|}{$0.1 \mathrm{~m}^{3} / \mathrm{s}$} & \multicolumn{2}{|c|}{$0.2 \mathrm{~m}^{3} / \mathrm{s}$} & \multicolumn{2}{|c|}{$0.3 \mathrm{~m}^{3} / \mathrm{s}$} \\
\hline & $\begin{array}{l}\text { Reach- } \\
\text { Averaged Cell } \\
\text { Flow Velocity }\end{array}$ & $\begin{array}{l}\text { Reach- } \\
\text { Averaged Cell } \\
\text { Flow Depth }\end{array}$ & $\begin{array}{l}\text { Reach- } \\
\text { Averaged Cell } \\
\text { Flow Velocity }\end{array}$ & $\begin{array}{l}\text { Reach- } \\
\text { Averaged Cell } \\
\text { Flow Depth }\end{array}$ & $\begin{array}{l}\text { Reach- } \\
\text { Averaged Cell } \\
\text { Flow Velocity }\end{array}$ & $\begin{array}{l}\text { Reach- } \\
\text { Averaged Cell } \\
\text { Flow Depth }\end{array}$ \\
\hline Threehills Creek & 0.04 & 0.34 & 0.05 & 0.45 & 0.05 & 0.51 \\
\hline Rosebud Creek & 0.06 & 0.28 & 0.08 & 0.39 & 0.10 & 0.48 \\
\hline Lonepine Creek & 0.05 & 0.41 & 0.07 & 0.57 & 0.06 & 0.63 \\
\hline
\end{tabular}


The results indicate the reach-averaged cell flow velocities and depths at a specific site within each set of three sites are generally within 10 to $30 \%$ of the sample means in regions NS4, SW1 and N6. This result is consistent with the results for Field Component 1 for the low flow Q2 range in region NS4.

By including the field data from both Field Components 1 and 2, there are 8 sets of two to four sites that have similar Q2 and Slp. The results of these data sets indicate that 7 of the 8 sets or about $90 \%$ have the reach-averaged cell flow velocities and depths at a specific site within 10 to $30 \%$ of the sample means of the two to four sites. These results, while not statistically rigorous, support the hypothesis that streams in a given region and with similar Q2 and Slp have similar reach average hydraulics.

\section{Analysis of the Results of the Reach-Averaged Distributions of Cell Flow Velocities and Depths}

Tables 5.7 and 5.8 present the percentages of cell flow velocities and depths at one discharge for the sites of Field Component 2. Appendix II provides comparable information for the other two discharges in tabular format. Appendix III presents all of the analyses of cell velocities and depth frequency distributions within pre-specified bin classes as bar charts, together with the site photos and their locations in each region.

A visual examination of the results indicates that streams of similar Slp over a range of Q2 in each of the four regions (NS4 North, NS4 South, SW1 and N6) display very similar cell velocity and depth distributions, especially within the bin classes with the highest percentages of occurrence. The range over which the cell flow velocities and depths occur are also generally similar among the self-similar sites. The similarity, judged based on visual inspection but not tested rigorously using any statistical method, seems to occur over a range of simulated discharges.

\section{Summary of Results}

Considering the limited data sets available and the inherent errors associated with the field data collection and the hydraulic analysis, the results from the hydraulic analysis based on the data of Fickd component 2 further support the hypothesis that the streams of similar Q2 and Slp within a 
given region have similar hydraulics. Based on the reach-averaged hydraulic parameters, the deviation from the same hydraulic condition is within 10 to $30 \%, 100 \%$ of the time for all the comparable sites in Field Component 2.

Table 5.7

Percent Distributions of Cell Flow Velocities $(\mathrm{m} / \mathrm{s})$ at One Simulated Discharge for Various Q2's in Regions NS4, SW1 and N6

\begin{tabular}{|c|c|c|c|c|c|c|c|c|c|c|c|c|}
\hline \multirow{2}{*}{$\begin{array}{l}\text { Stream } \\
\text { Name }\end{array}$} & \multirow{2}{*}{$\begin{array}{c}\text { Region - Q2 } \\
\text { Range (Sub- } \\
\text { division) }\end{array}$} & \multirow{2}{*}{$\begin{array}{c}\text { Discharge } \\
\left(\mathrm{m}^{3} / \mathrm{s}\right)\end{array}$} & \multicolumn{10}{|c|}{ Percentage of Cell Flow Velocity (m/s) within Each Bin Class } \\
\hline & & & 0.1 & 0.2 & 0.3 & 0.4 & 0.5 & 0.6 & 0.7 & 0.8 & 0.9 & 1.0 \\
\hline $\begin{array}{l}\text { Dogpound } \\
\text { Creek }\end{array}$ & $\begin{array}{l}\text { NS4 Medium } \\
\text { (North) }\end{array}$ & 2.5 & 50 & 6 & 15 & 11 & 7 & 0 & 1 & 4 & 2 & 1 \\
\hline Fish Creek & $\begin{array}{l}\text { NS4 Medium } \\
\text { (South) }\end{array}$ & 2.5 & 6 & 8 & 15 & 18 & 4 & 12 & 10 & 5 & 7 & 5 \\
\hline $\begin{array}{l}\text { Willow } \\
\text { Creek }\end{array}$ & $\begin{array}{l}\text { NS4 Medium } \\
\text { (South) }\end{array}$ & 2.5 & 26 & 29 & 19 & 5 & 6 & 1 & 3 & 4 & 4 & 1 \\
\hline $\begin{array}{l}\text { James } \\
\text { River }\end{array}$ & $\begin{array}{l}\text { NS4 High } \\
\text { (North) }\end{array}$ & 8.5 & 7 & 4 & 1 & 3 & 12 & 6 & 13 & 23 & 6 & 9 \\
\hline $\begin{array}{l}\text { Little Red } \\
\text { Deer River }\end{array}$ & $\begin{array}{l}\text { NS4 High } \\
\text { (North) }\end{array}$ & 8.5 & 0 & 0 & 0 & 3 & 2 & 6 & 14 & 19 & 21 & 19 \\
\hline $\begin{array}{l}\text { Elbow } \\
\text { River }\end{array}$ & $\begin{array}{l}\text { NS4 High } \\
\text { (South) }\end{array}$ & 8.5 & 9 & 2 & 4 & 9 & 2 & 1 & 8 & 4 & 8 & 4 \\
\hline $\begin{array}{l}\text { Highwood } \\
\text { River }\end{array}$ & SW1 Low & 2.0 & 10 & 1 & 9 & 14 & 14 & 8 & 18 & 5 & 6 & 7 \\
\hline $\begin{array}{l}\text { Oldman } \\
\text { River }\end{array}$ & SW1 Low & 2.0 & 9 & 3 & 2 & 8 & 25 & 14 & 12 & 10 & 9 & 6 \\
\hline $\begin{array}{l}\text { Dutch } \\
\text { Creek }\end{array}$ & SW1 Low & 2.0 & 7 & 3 & 10 & 5 & 5 & 13 & 19 & 15 & 15 & 5 \\
\hline $\begin{array}{l}\text { Crowsnest } \\
\text { River }\end{array}$ & $\begin{array}{c}\text { SW1 } \\
\text { Medium }\end{array}$ & 2.5 & 8 & 7 & 10 & 14 & 25 & 16 & 17 & 1 & 1 & 0 \\
\hline $\begin{array}{l}\text { Castle } \\
\text { River }\end{array}$ & $\begin{array}{c}\text { SW1 } \\
\text { Medium }\end{array}$ & 2.5 & 34 & 7 & 8 & 34 & 5 & 8 & 2 & 2 & 1 & 0 \\
\hline Lee Creek & $\begin{array}{c}\text { SW1 } \\
\text { Medium }\end{array}$ & 2.5 & 20 & 4 & 12 & 9 & 13 & 18 & 8 & 3 & 3 & 1 \\
\hline $\begin{array}{l}\text { Highwood } \\
\text { River }\end{array}$ & SW1 High & 5.5 & 9 & 6 & 7 & 18 & 16 & 12 & 11 & 7 & 15 & 2 \\
\hline $\begin{array}{l}\text { Crowsnest } \\
\text { River }\end{array}$ & SW1 High & 5.5 & 7 & 8 & 7 & 10 & 24 & 14 & 5 & 10 & 12 & 3 \\
\hline Belly River & SW1 High & 5.5 & 15 & 8 & 15 & 27 & 22 & 3 & 5 & 3 & 0 & 2 \\
\hline $\begin{array}{l}\text { Threehills } \\
\text { Creek }\end{array}$ & N6 Low & 0.2 & 89 & 11 & 0 & 0 & 0 & 0 & 0 & 0 & 0 & 0 \\
\hline $\begin{array}{l}\text { Rosebud } \\
\text { River }\end{array}$ & N6 Low & 0.2 & 65 & 34 & 0 & 1 & & 0 & 0 & 0 & 0 & 0 \\
\hline $\begin{array}{l}\text { Lonepine } \\
\text { Creek }\end{array}$ & N6 Low & 0.2 & 80 & 20 & 0 & 0 & 0 & 0 & 0 & 0 & 0 & 0 \\
\hline
\end{tabular}


Table 5.8

Percent Distributions of Cell Flow Depths at One Simulated Discharge for Various Q2's in Regions NS4, SW1 and N6

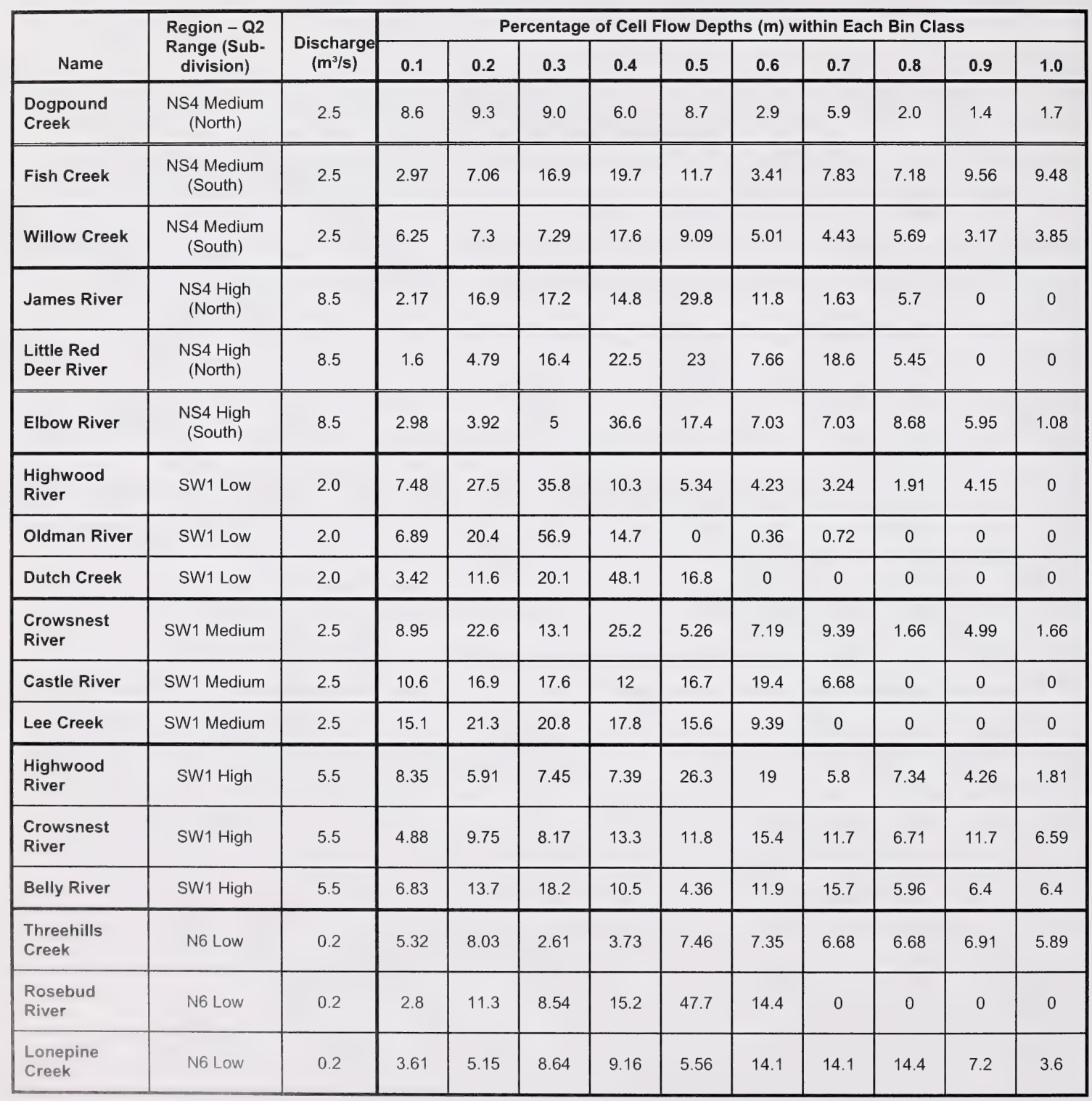




\subsubsection{Conclusion Regarding the Hypothesis of Hydraulic Similarity}

Based on the results of the hydraulic analysis for the surveyed sites in Field Components 1 and 2 (i.e., the results for both the reach-averaged cell flow velocities and depths and their spatial distributions), it can be concluded that the similarity hypothesis (i.e., streams within a self-similar region and having similar Q2 and Slp should have similar hydraulics) is reasonably supported, although not rigorously tested using a statistical method due to the small sample sizes. Therefore, as a preliminary finding, it appears reasonable to transfer hydraulics between streams with similar Q2 and Slp within the same hydrologic-geomorphic region.

Based on the calculated reach-averaged cell flow velocities and depths, the deviation from the same hydraulic condition is within 10 to $30 \%$, about $90 \%$ of the time in consideration of all the comparable sites in Field Components 1 and 2.

\subsubsection{Field Component 3}

\section{Variation or Sensitivity of Hydraulics with Respect to Q2}

Field Component 3 involved 17 sites in region NS4. In this region, the reach-average stream bed slopes are similar to one another. However, the Q2's vary from the low to high range. Tables 5.9 and 5.10 show the percentages of the cell flow velocities and depths of the 17 sites in region NS4 (10 in NS4 North and 7 in NS4 South) associated with one simulated discharge. Detailed results of the other simulated discharges and of the reach-averaged cell flow velocities and depths are provided in Appendix IV in tabular format and in Appendix V on bar charts. The ranges of cell velocities and depths reported in the tables have been truncated for presentation purposes. Detailed results are provided separately on CD-ROM.

The original design for Field Component 3 was to collect field data and conduct the data analysis to determine if the reach averages and spatial distributions of cell flow velocities and depths for a given Slp have well-defined relationships with Q2 in order to refine, or potentially eliminate, the Q2 classes. If definable based on the available data, such relationships would simplify the stream classification and hydraulics transfer methodologies by replacing the discreet classes defined for Q2 with a relationship that could be applied over the entire range of Q2. However, the results show that the limited number of sites (or the small sample size) and the relatively large errors in 
estimating the reach-average hydraulic parameters based on the limited field data, cannot support definition of such relationships based on Q2 alone $\mathrm{s}$ in a reliable manner because of a large degree of data scattering on the relational plots.

Table 5.9

Percentage Distributions of Cell Flow Velocities $(\mathrm{m} / \mathrm{s})$ for the Streams with Various Q2's in Region NS4

\begin{tabular}{|c|c|c|c|c|c|c|c|c|c|c|c|c|c|}
\hline \multirow[b]{2}{*}{ Reach No. } & \multirow{2}{*}{$\begin{array}{l}\text { Class } \\
\text { (Sub- } \\
\text { Region of } \\
\text { NS4) }\end{array}$} & \multirow[b]{2}{*}{$\begin{array}{c}\text { Q2 } \\
\left(\mathrm{m}^{3} / \mathrm{s}\right)\end{array}$} & \multirow{2}{*}{$\begin{array}{c}\text { Simulated } \\
Q \\
\left(\mathrm{~m}^{3} / \mathrm{s}\right)\end{array}$} & \multicolumn{10}{|c|}{ Percentage of Cell Flow Velocity (m/s) within Each Bin Class } \\
\hline & & & & 0.1 & 0.2 & 0.3 & 0.4 & 0.5 & 0.6 & 0.7 & 0.8 & 0.9 & 1.0 \\
\hline NS4-Reach01 & 1 (North) & 4 & 1.0 & 63 & 26 & 8 & 2 & 1 & 0 & 0 & 0 & 0 & 0 \\
\hline NS4-Reach02 & 1 (North) & 5 & 1.0 & 10 & 26 & 47 & 16 & 0 & 1 & 1 & 0 & 0 & 0 \\
\hline NS4-Reach19 & 1 (North) & 9 & 1.0 & 57 & 12 & 4 & 1 & 8 & 4 & 0 & 1 & 0 & 4 \\
\hline NS4-Reach20 & 1 (North) & 11 & 1.0 & 63 & 10 & 11 & 3 & 3 & 9 & 0 & 0 & 0 & 0 \\
\hline NS4-Reach07 & 1 (North) & 16 & 1.0 & 24 & 12 & 32 & 18 & 9 & 1 & 1 & 0 & 0 & 0 \\
\hline NS4-Reach08 & 1 (North) & 17 & 1.0 & 30 & 24 & 20 & 6 & 12 & 8 & 0 & 0 & 0 & 0 \\
\hline NS4-Reach09 & 1 (North) & 20 & 1.0 & 44 & 13 & 10 & 3 & 5 & 4 & 6 & 7 & 4 & 1 \\
\hline NS4-Reach10 & 2 (North) & 24 & 4.0 & 14 & 9 & 6 & 5 & 7 & 15 & 5 & 26 & 1 & 1 \\
\hline NS4-Reach21 & 2 (North) & 27 & 4.0 & 44 & 21 & 13 & 6 & 3 & 2 & 8 & 0 & 0 & 0 \\
\hline NS4-Reach12 & 2 (North) & 30 & 4.0 & 3 & 4 & 8 & 8 & 3 & 9 & 7 & 8 & 3 & 3 \\
\hline NS4-Reach14 & 3 (North) & 45 & 4.0 & 13 & 16 & 21 & 31 & 9 & 5 & 0 & 1 & 0 & 0 \\
\hline NS4-Reach06 & 1 (South) & 13 & 1.0 & 99 & 0 & 0 & 0 & 0 & 0 & 0 & 0 & 0 & 0.0 \\
\hline NS4-Reach22 & 2 (South) & 38 & 4.0 & 13 & 3 & 8 & 11 & 21 & 3 & 12 & 6 & 12 & 5 \\
\hline NS4-Reach15 & 2 (South) & 55 & 4.0 & 23 & 17 & 7 & 13 & 10 & 3 & 5 & 1 & 5 & 5 \\
\hline NS4-Reach16 & 3 (South) & 62 & 6.0 & 18 & 11 & 9 & 9 & 11 & 20 & 15 & 5 & 1 & 1 \\
\hline NS4-Reach17 & 3 (South) & 88 & 6.0 & 17 & 17 & 12 & 16 & 15 & 10 & 10 & 2 & 2 & 0 \\
\hline NS4-Reach18 & 4 (South) & 111 & 6.0 & 9 & 2 & 7 & 16 & 20 & 23 & 11 & 9 & 1 & 1 \\
\hline
\end{tabular}

Q2 Class for NS4 - North

Class 1 (North) $<20 \mathrm{~m}^{3} / \mathrm{s}$

Class 2 (North) $20-40 \mathrm{~m}^{3} / \mathrm{s}$

Class 3 (North) $>40 \mathrm{~m}^{3} / \mathrm{s}$
Q2 Class for NS4 - South

Class 1 (South) $\quad<30 \mathrm{~m}^{3} / \mathrm{s}$

Class 2 (South) $\quad 30-60 \mathrm{~m}^{3} / \mathrm{s}$

Class 3 (South) $\quad 60-100 \mathrm{~m}^{3} / \mathrm{s}$

Class 4 (South) $\quad>100 \mathrm{~m}^{3} / \mathrm{s}$ 
Table 5.10

Percent Distributions of Cell Flow Depths (m) for the Streams with Various Q2's in Region NS4

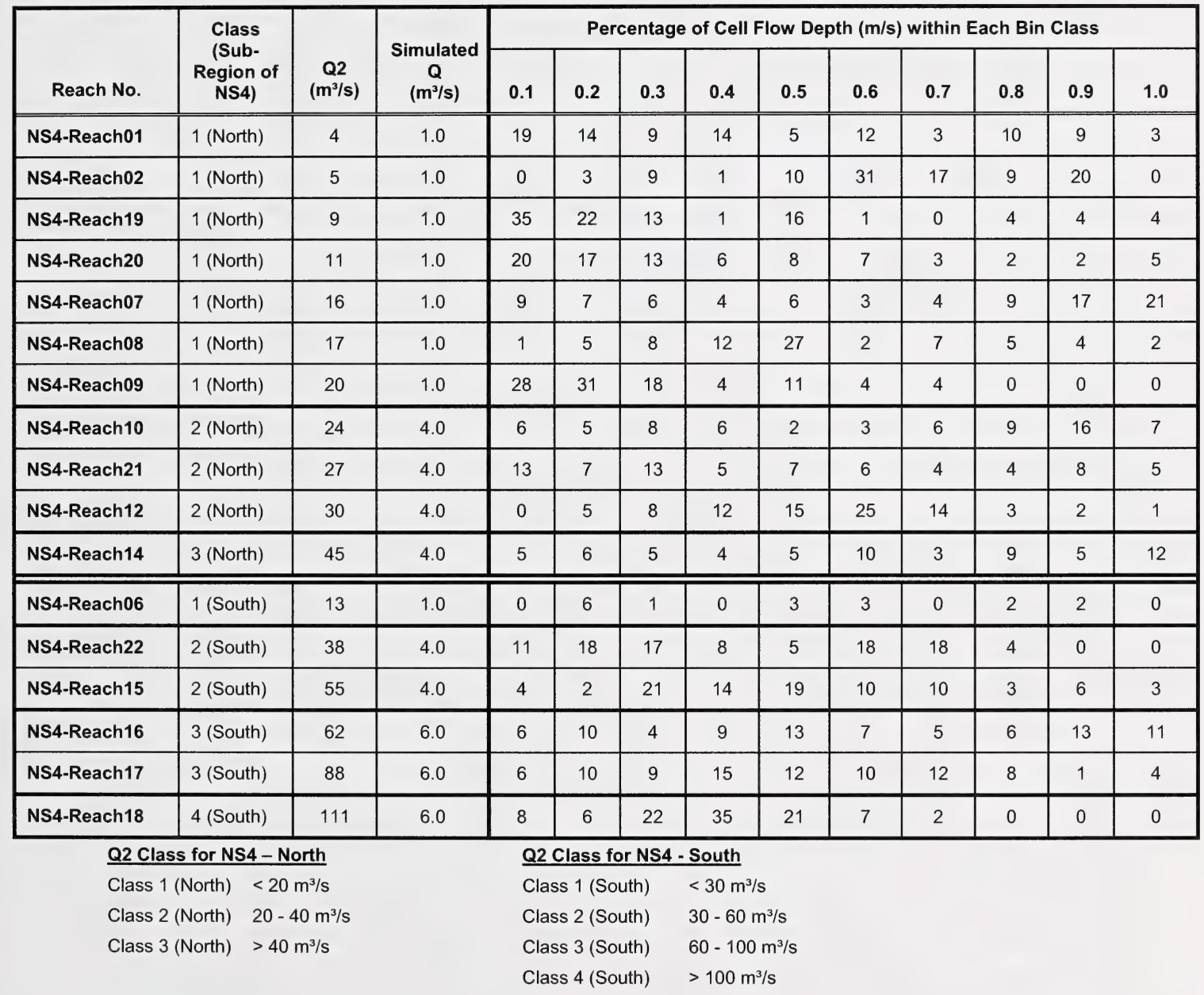

Even without the definable relationships, the preliminary scheme of having five Q2 classes with a given Slp can be examined based on the data for the 17 sites in NS4, to determine if such classification can group the stream reaches with similar hydraulics together in a reasonable manner. An analysis of the hydraulic analysis results, by visual examination of the calculated reach-averaged cell flow velocities and depths and their distributions and the geomorphic characteristics of the survey sites indicated by the site photos, shows that the surveyed sites can 
be grouped as indicated in Tables 5.9 and 5.10. This analysis suggests that the preliminary ranges of Q2 for the stream classification can be refined based on the available data for NS4, as indicated below.

Preliminary Classification Scheme

\begin{tabular}{|c|c|}
\hline Class & Q2 $\left(\mathrm{m}^{3} / \mathbf{s}\right)$ \\
\hline 1 & $<25$ \\
\hline 2 & $25-50$ \\
\hline 3 & $50-100$ \\
\hline 4 & $100-200$ \\
\hline 5 & $>200$ \\
\hline
\end{tabular}

Classification Based on Field Data

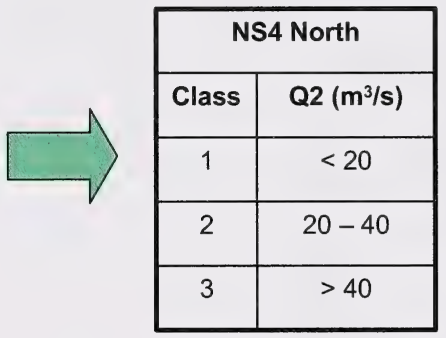

The results of the analysis and Q2 range refinement for the NS4 region as mentioned above, support the conclusion that the proposed classification scheme for Q2 is reasonable, although some minor refinements to the threshold values of the various ranges are needed.

\section{Variation or Sensitivity of Hydraulics with Respect to SIp and Q2}

Field Component 3 involved data collection at 20 sites in region N6, with an intent to assess the variation or sensitivity of the hydraulic conditions with respect to Slp and Q2. These sites have Slp's which can be sorted into two Slp classes: 11 sites with Slp less than 0.0015 , while the remaining 7 sites with Slp between 0.0015 and 0.0030 . These sites have Q2 ranging from 4 to $40 \mathrm{~m}^{3} / \mathrm{s}$. Reach 01 was removed from the study since the channel was completely vegetated at the time of the field survey and Reach 19 was dropped from the assessment because it appeared to be an outlier.

Tables 5.11 and 5.12 present the percentages of the cell flow velocities and depths associated one discharge for the 18 sites. The discharge to be simulated was selected so that reasonable comparisons could be made between streams within a given group that have a wide range of 
Q2's. The detailed results for the other discharges and for the reach-averaged cell flow velocities and depths are provided in Appendix IV in tabular format and in Appendix V on bar charts.

Table 5.11

Percent Distributions of Cell Flow Velocities $(\mathrm{m} / \mathrm{s})$ for Streams with Various Q2's and Two Classes of Slopes in Region N6

\begin{tabular}{|c|c|c|c|c|c|c|c|c|c|c|c|c|c|}
\hline \multirow[b]{2}{*}{ Reach No. } & \multirow[b]{2}{*}{ Class } & \multirow{2}{*}{$\begin{array}{c}Q 2 \\
\left(m^{3} / s\right)\end{array}$} & \multirow{2}{*}{$\begin{array}{c}Q \\
\left(m^{3} / s\right)\end{array}$} & \multicolumn{10}{|c|}{ Percentage of Cell Flow Velocity $(\mathrm{m} / \mathrm{s})$ within Each Bin Class } \\
\hline & & & & 0.1 & 0.2 & 0.3 & 0.4 & 0.5 & 0.6 & 0.7 & 0.8 & 0.9 & 1.0 \\
\hline N6-Reach02 & $1-\mathrm{S} 1$ & 4 & 0.7 & 95 & 1 & 0 & 0 & 1 & 1 & 0 & 1 & 0 & 0 \\
\hline N6-Reach04 & $1-\mathrm{S} 1$ & 6 & 0.7 & 100 & 0 & 0 & 0 & 0 & 0 & 0 & 0 & 0 & 0 \\
\hline N6-Reach05 & $1-S 1$ & 7 & 0.7 & 54 & 26 & 16 & 5 & 0 & 0 & 0 & 0 & 0 & 0 \\
\hline N6-Reach06 & $1-S 1$ & 8 & 0.7 & 75 & 25 & 0 & 0 & 0 & 0 & 0 & 0 & 0 & 0 \\
\hline N6-Reach07 & $1-S 1$ & 9 & 0.7 & 80 & 18 & 1 & 0 & 0 & 0 & 0 & 0 & 0 & 0 \\
\hline N6-Reach10 & $1-S 1$ & 12 & 0.7 & 55 & 33 & 12 & 0 & 0 & 0 & 0 & 0 & 0 & 0 \\
\hline N6-Reach11 & $1-S 1$ & 14 & 0.7 & 85 & 15 & 0 & 0 & 0 & 0 & 0 & 0 & 0 & 0 \\
\hline N6-Reach14 & $2-S 1$ & 17 & 1.0 & 53 & 25 & 15 & 5 & 1 & 1 & 0 & 0 & 0 & 0 \\
\hline N6-Reach16 & $2-S 1$ & 25 & 1.0 & 25 & 8 & 41 & 24 & 2 & 0 & 0 & 0 & 0 & 0 \\
\hline N6-Reach17 & $2-S 1$ & 26 & 1.0 & 7 & 6 & 20 & 21 & 47 & 0 & 0 & 0 & 0 & 0 \\
\hline N6-Reach18 & $3-S 1$ & 31 & 1.0 & 43 & 56 & 1 & 0 & 0 & 0 & 0 & 0 & 0 & 0 \\
\hline N6-Reach08 & $1-S 2$ & 10 & 0.7 & 100 & 0 & 0 & 0 & 0 & 0 & 0 & 0 & 0 & 0 \\
\hline N6-Reach09 & $1-S 2$ & 12 & 0.7 & 64 & 31 & 3 & 1 & 0 & 0 & 0 & 0 & 0 & 0 \\
\hline N6-Reach12 & $2-S 2$ & 15 & 1.0 & 75 & 15 & 10 & 0 & 0 & 0 & 0 & 0 & 0 & 0 \\
\hline N6-Reach13 & $2-S 2$ & 16 & 1.0 & 70 & 7 & 20 & 0 & 0 & 0 & 1 & 1 & 0 & 1 \\
\hline N6-Reach15 & $2-S 2$ & 18 & 1.0 & 50 & 8 & 4 & 6 & 12 & 2 & 3 & 8 & 0 & 5 \\
\hline N6-Reach20 & $3-S 2$ & 36 & 1.0 & 82 & 2 & 6 & 4 & 1 & 4 & 0 & 0 & 0 & 0 \\
\hline N6-Reach21 & $3-S 2$ & 37 & 1.0 & 28 & 11 & 25 & 11 & 23 & 2 & 0 & 0 & 0 & 0 \\
\hline
\end{tabular}

Q2 Class for Slope $1<0.0015$

Class $1-\mathrm{S} 1<15 \mathrm{~m}^{3} / \mathrm{s}$

Class 2-S1 $15-30 \mathrm{~m}^{3} / \mathrm{s}$

Class 3-S1 $>30 \mathrm{~m}^{3} / \mathrm{s}$
Q2 Class for $0.0015<$ Slope $2<0.0030$

Class 1-S2

$<15 \mathrm{~m}^{3} / \mathrm{s}$

Class 2-S2

Class 3-S2
$15-30 \mathrm{~m}^{3} / \mathrm{s}$

$>30 \mathrm{~m}^{3} / \mathrm{s}$ 
Table 5.12

Percent Distributions of Cell Flow Depths (m) for Streams with Various Q2's and Two Classes of Slopes in Region N6

\begin{tabular}{|c|c|c|c|c|c|c|c|c|c|c|c|c|c|}
\hline \multirow{2}{*}{ Reach No. } & \multirow[b]{2}{*}{ Class } & \multirow{2}{*}{$\begin{array}{c}\text { Q2 } \\
\left(\mathrm{m}^{3} / \mathrm{s}\right)\end{array}$} & \multirow{2}{*}{$\begin{array}{c}Q \\
\left(m^{3} / s\right)\end{array}$} & \multicolumn{10}{|c|}{ Percentage of Cell Flow Depth $(m)$ within Each Bin Class } \\
\hline & & & & 0.1 & 0.2 & 0.3 & 0.4 & 0.5 & 0.6 & 0.7 & 0.8 & 0.9 & 1.0 \\
\hline N6-Reach02 & $1-\mathrm{S} 1$ & 4 & 0.7 & 8 & 5 & 6 & 6 & 8 & 3 & 2 & 5 & 0 & 2 \\
\hline N6-Reach04 & $1-\mathrm{S} 1$ & 6 & 0.7 & 1 & 7 & 3 & 1 & 5 & 4 & 2 & 6 & 2 & 1 \\
\hline N6-Reach05 & 1-S1 & 7 & 0.7 & 12 & 8 & 12 & 10 & 5 & 3 & 4 & 5 & 18 & 7 \\
\hline N6-Reach06 & $1-S 1$ & 8 & 0.7 & 5 & 5 & 7 & 3 & 4 & 3 & 2 & 3 & 0 & 4 \\
\hline N6-Reach07 & $1-\mathrm{S} 1$ & 9 & 0.7 & 3 & 5 & 3 & 2 & 4 & 5 & 3 & 12 & 7 & 0 \\
\hline N6-Reach10 & $1-S 1$ & 12 & 0.7 & 21 & 16 & 8 & 4 & 6 & 2 & 3 & 11 & 4 & 3 \\
\hline N6-Reach11 & $1-S 1$ & 14 & 0.7 & 8 & 9 & 1 & 1 & 7 & 3 & 2 & 2 & 2 & 6 \\
\hline N6-Reach14 & $2-S 1$ & 17 & 1.0 & 4 & 8 & 16 & 10 & 13 & 22 & 27 & 0 & 0 & 0 \\
\hline N6-Reach16 & $2-S 1$ & 25 & 1.0 & 0 & 16 & 8 & 10 & 17 & 11 & 35 & 2 & 0 & 0 \\
\hline N6-Reach17 & $2-S 1$ & 26 & 1.0 & 0 & 2 & 2 & 18 & 46 & 26 & 7 & 0 & 0 & 0 \\
\hline N6-Reach18 & $3-S 1$ & 31 & 1.0 & 5 & 5 & 5 & 3 & 0 & 5 & 9 & 8 & 10 & 10 \\
\hline N6-Reach08 & $1-S 2$ & 10 & 0.7 & 4 & 8 & 7 & 7 & 4 & 3 & 8 & 4 & 6 & 22 \\
\hline N6-Reach09 & $1-S 2$ & 12 & 0.7 & 4 & 2 & 9 & 12 & 7 & 6 & 8 & 10 & 23 & 9 \\
\hline N6-Reach12 & 2-S2 & 15 & 1.0 & 0 & 9 & 1 & 2 & 7 & 3 & 8 & 3 & 7 & 7 \\
\hline N6-Reach13 & $2-S 2$ & 16 & 1.0 & 12 & 13 & 22 & 19 & 2 & 5 & 0 & 5 & 5 & 5 \\
\hline N6-Reach15 & $2-S 2$ & 18 & 1.0 & 22 & 16 & 8 & 12 & 9 & 10 & 2 & 5 & 8 & 2 \\
\hline N6-Reach20 & $3-S 2$ & 36 & 1.0 & 8 & 15 & 13 & 13 & 9 & 9 & 5 & 0 & 3 & 0 \\
\hline N6-Reach21 & $3-S 2$ & 37 & 1.0 & 6 & 2 & 3 & 29 & 16 & 6 & 6 & 12 & 19 & 0 \\
\hline
\end{tabular}

Q2 Class for Slope $1<0.0015$

Class 1 - $\mathrm{S} 1<15 \mathrm{~m}^{3} / \mathrm{s}$

Class 2-S1 $15-30 \mathrm{~m}^{3} / \mathrm{s}$

Class $3-\mathrm{S} 1>30 \mathrm{~m}^{3} / \mathrm{s}$

\section{Q2 Class for $0.0015<$ Slope $2<0.0030$}

Class 1-S2

Class 2-S2

Class 3-S2
$<15 \mathrm{~m}^{3} / \mathrm{s}$

$15-30 \mathrm{~m}^{3} / \mathrm{s}$

$>30 \mathrm{~m}^{3} / \mathrm{s}$

The hydraulic analysis results were analyzed by a visual examination of the calculated reachaveraged cell flow velocities and depths and their distributions and the geomorphic characteristics of the survey sites indicated by the site photos. The assessment of distribution patterns and site features suggests that the surveyed sites can be grouped as indicated in Tables 5.11 and 5.12 This analysis suggests that the preliminary ranges of Slp and Q2 for the stream classification should be refined for the N6 region, as indicated below. 
Preliminary Classification Scheme Classification Based on Field Data for N6

\begin{tabular}{|c|c|}
\hline Class & Slope \\
\hline 1 & $<0.003$ \\
\hline 2 & $0.003-0.006$ \\
\hline 3 & $0.006-0.01$ \\
\hline 4 & $0.01-0.02$ \\
\hline 5 & $>0.02$ \\
\hline
\end{tabular}

\begin{tabular}{|c|c|}
\hline \multicolumn{2}{|c|}{$S<0.0015$} \\
\hline Class & Q2 $\left(\mathrm{m}^{3} / \mathrm{s}\right)$ \\
\hline 1 & $<15$ \\
\hline 2 & $15-30$ \\
\hline 3 & $>30$ \\
\hline
\end{tabular}

\begin{tabular}{|c|c|}
\hline \multicolumn{2}{|c|}{$0.0015<\mathrm{S}<0.003$} \\
\hline Class & $\mathbf{Q 2}\left(\mathrm{m}^{3} / \mathrm{s}\right)$ \\
\hline 1 & $<15$ \\
\hline 2 & $15-30$ \\
\hline 3 & $>30$ \\
\hline
\end{tabular}

\begin{tabular}{|c|c|}
\hline Class & Q2 $\left(\mathrm{m}^{3} / \mathbf{s}\right)$ \\
\hline 1 & $<25$ \\
\hline 2 & $25-50$ \\
\hline 3 & $50-100$ \\
\hline 4 & $100-200$ \\
\hline 5 & $>200$ \\
\hline
\end{tabular}

\subsubsection{Conclusions Regarding Class Ranges for Q2 and SIp}

The analyses of the hydraulic results of Field Component 3 support the following conclusions:

- The scheme of grouping Q2's and Slp's within a given hydrologic-geomorphic region into a number of classes, has been shown to be a reasonable classification approach, although the preliminarily-proposed threshold values need refinements to suit the variation of the hydraulic conditions with the region.

- Different regions may have different threshold values for grouping the stream reaches into various classes, but the general approach of classification based on ranges of Q2's and Slp's is the same for all the regions. 
- The proposed threshold values will need to be updated when more data are available for each region, but the preliminarily-proposed threshold values for the various classes of Q2 and Slp can be used as a good guide.

The results of the data analysis indicate the requirement to refine the classification for the low Q2 classes in the NS4 region and for the low Q2 and Slp classes in the N6 region. This result is logical, since the stream reaches in the prairies (N6) region generally have lower values of Q2 and Slp compared to stream reaches in the mountainous regions. It is not expected that the total number of Q2 or Slp classes would largely exceed the originally-proposed number of 5 in the NS4 and N6 regions, because these two regions have few streams with very high Q2 and Slp. 


\section{ASSESSMENT OF STREAM HYDRAULICS TRANSFER PROTOCOLS}

\subsection{Extrapolation Approaches of Other Jurisdictions}

The end goal of the IFN Classification Project is to develop an approach that would allow for the extrapolation or transfer of IFN results measured at one stream reach to a similar, unmeasured stream reach within the same hydrologic-geomorphic region. The focus of the current phase of the Project was to establish and validate the stream classification method and to make a preliminary assessment of possible options for the IFN extrapolation. Tools for extrapolating IFNs are not common. However, such tools have been receiving more attention in recent years.

The Toe-width method (Swift 1976, 1979) is an early example of an extrapolation method that is commonly applied in Washington State to define minimum flows (Geller 2003). The Toe-width approach was developed to define a single minimum flow for spawning and rearing life stages of salmon and steelhead trout based on a relationship between "optimum" spawning habitat area and the width of the stream at the toe of the bank. Due to the limited number of life stages that the method was developed for and the inherent similarity of salmon spawning streams, this approach is not flexible enough for application to the wide range of hydrologic-geomorphic conditions characterizing streams in Alberta. In addition, the Toe-width method results in a single minimum IFN value and recent IFN applications in Alberta have tended to avoid such restrictive approaches (Clipperton et al. 2003). The minimum flow result may be in large part to the approach of defining IFNs in Washington State rather than a limitation of the method to develop a variable flow regime if protocols to do so were developed.

Hatfield and Bruce (2000) found a relationship between a hydrologic variable (mean annual flow) and the peak of the weighted useable area (WUA) curve for a wide range of streams in the west coast of Canada and the United States. This study was carried out on a broad range of stream types and life stages of fish. However, this approach also focused on a single flow value to define the IFN. Recent efforts in France have also shown that it is possible to predict detailed hydraulic characteristics as well as changes in a habitat-discharge relationship (essentially a WUA curve) using simple measures of reach-averaged hydraulic characteristics (Lamouroux et al. 1995, 1998; Lamouroux and Carpa 2002, Lamouroux and Souchon 2002). Both the Hatfield and Bruce 
(2000) and the series of studies in France suggest that extrapolation of IFN results may be achievable across a relatively broad scale using fairly easily obtainable parameters.

Recent IFN efforts in the Nooksack River Basin in Washington State have established a stream stratification (i.e., classification) approach in an effort to extrapolate results from measured sites to unmeasured sites (Hardy 2000). An expert workshop was held to discuss potential instream flow extrapolation options that could be investigated (Hardy 2002). As a result of the workshop, four methods of extrapolation were proposed: a mass balance method, a flow volume ratio method, and two different geomorphic-based linkage methods. The first two approaches assume that a simple relationship between a hydrologic variable and the IFN can be established using varying degrees of scaling. There are some differences between the two proposed geomorphicbased approaches. The first approach proposes that a relationship could be developed between a key factor (e.g., drainage area) and the IFN at an intensive site with the IFN then being extrapolated to an unmeasured site. The second geomorphic approach would involve developing a relationship between drainage characteristics and hydraulic parameters at an intensive site to predict the hydraulic parameters at the unmeasured site, from which the IFN would be estimated. Initial Nooksack study findings suggest that all of the proposed approaches have achieved prediction capability to varying degrees and the study authors suggest the potential for one approach being more suitable in one region and another approach in a different region should not be disregarded (Saraeva and Hardy 2004).

\subsection{Preliminary Testing of Extrapolation Results for the SSRB}

The focus of this report has been on validating a stream classification method, which is based on hydrologic-geomorphic regionalization and classifying stream reaches in a given region based two key parameters, namely Q2 and Slp. This approach is similar to the geomorphic-based approaches proposed by Hardy (2002). In these or other approaches, a WUA curve will have to be created at some point in the process in order to define a fish habitat-based IFN for an unmeasured stream reach. The WUA curve is the basic "currency" for evaluating changes in fish habitat with changes in discharge for defining an IFN. WUA curves are a product of the stream hydraulics (flow depth and velocity) and habitat suitability criteria (HSC) defined for those parameters. With the successful validation of the assumption that the streams within a single hydrologic-geomorphic region with similar Q2 and reach slope have similar hydraulics, it would 
then follow that WUA curves should also be similar assuming identical target management species.

Applying the WUA curve results from a measured stream reach directly to an unmeasured stream reach with similar Q2 and Slp would be a simple approach to extrapolating IFN results as no modification or scaling would be necessary. To test this concept, the WUA results from three previously available PHABSIM sites at three different Q2 ranges and in two different regions were compared with the data collected for this Project. Data from the Elbow River Highway 22 Study Reach (ASRD unpublished data), Willow Creek Study Reach 5 (Fernet et al. 1992) and Belly River Study Reach 4 (Bjornson and Fernet 1989) were used for the comparison since these sites were located within regions where data were collected as a component of the current Project (Table 6.1). Due to the limited number of PHABSIM study sites from Alberta that fit within the classification scheme and the availability of the corresponding sites measured for this Project, the sites from region NS4 were not divided into north-south sub-regions, as recommended from the hydraulic analysis, to allow some initial comparisons to be conducted.

Table 6.1

Characteristics of the PHABSIM Study Sites Used to Compare Results from the Rapid Assessment Sites of this Project

\begin{tabular}{|l|c|c|c|c|c|}
\hline \multicolumn{1}{|c|}{ PHABSIM Site } & $\begin{array}{c}\text { Estimated } \\
\mathbf{Q 2}\left(\mathbf{m}^{\mathbf{3}} \mathbf{s}\right)\end{array}$ & $\begin{array}{c}\text { Drainage Area } \\
\left(\mathbf{k m}^{\mathbf{2}}\right)\end{array}$ & $\begin{array}{c}\text { Number of } \\
\text { Transects }\end{array}$ & Region & Q2 Category \\
\hline Elbow River & 65 & 984 & 18 & NS4 & High \\
\hline Willow Creek & 26 & 312 & 8 & NS4 & Medium \\
\hline Belly River & 56 & 510 & 7 & SW1 & High \\
\hline
\end{tabular}

Two sets of HSC data were used to test similarity: one set with a narrowly defined suitability for flow depth and velocity and one with a broadly defined suitability for flow depth and velocity. Rainbow trout (Oncorhynchus mykiss) fry HSC were used as an example of a narrow set of HSC and mountain whitefish (Prosopium williamsoni) adult HSC were used as an example of a broad set of HSC. These HSC were developed for use in the SSRB and were presented in Clipperton et al. (2003). The two different types of curves were selected to test the sensitivity of the results to different HSC functions. The results from this comparison are provided in Figures 6.1 to 6.3 . 


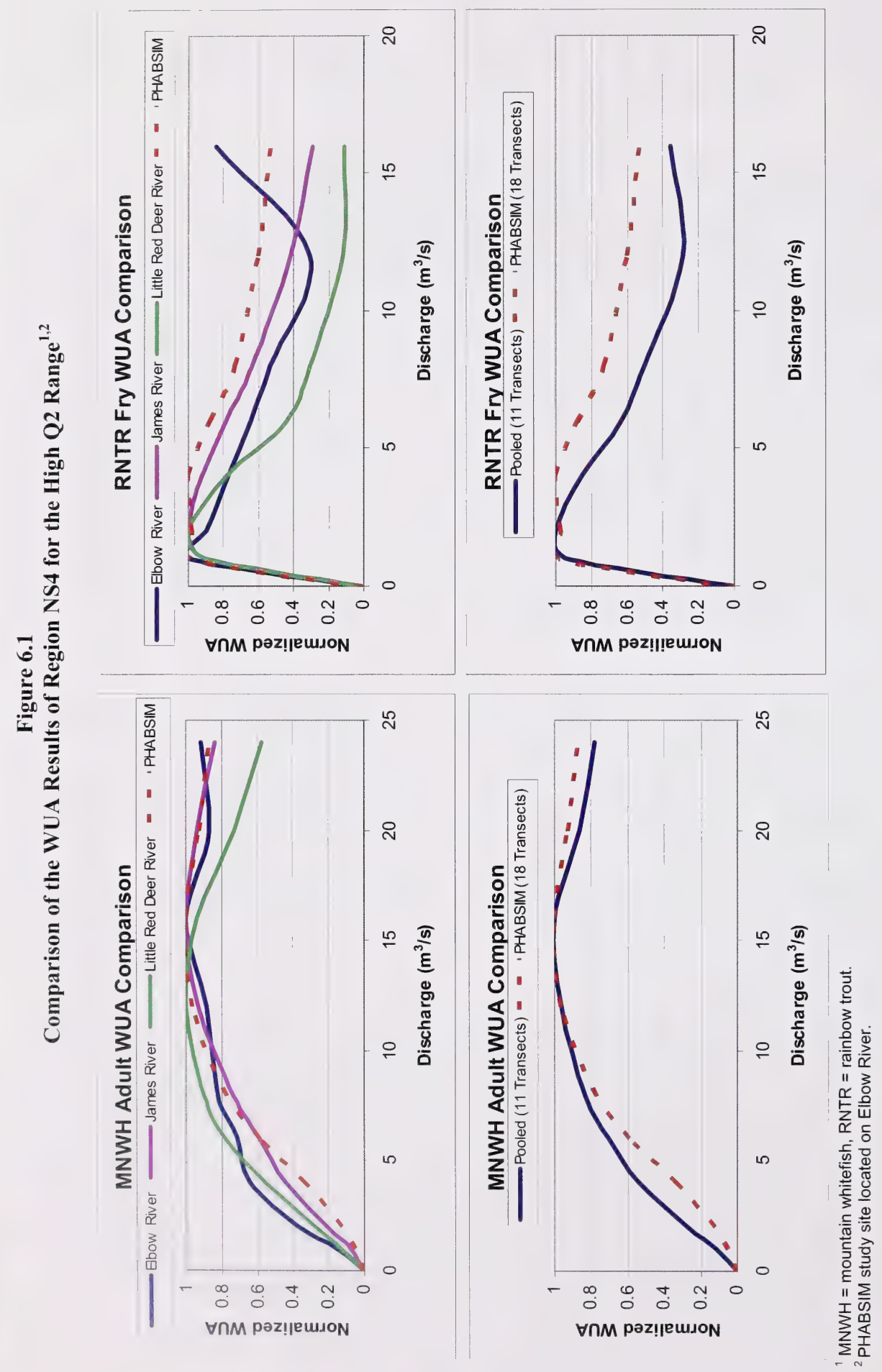

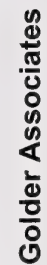




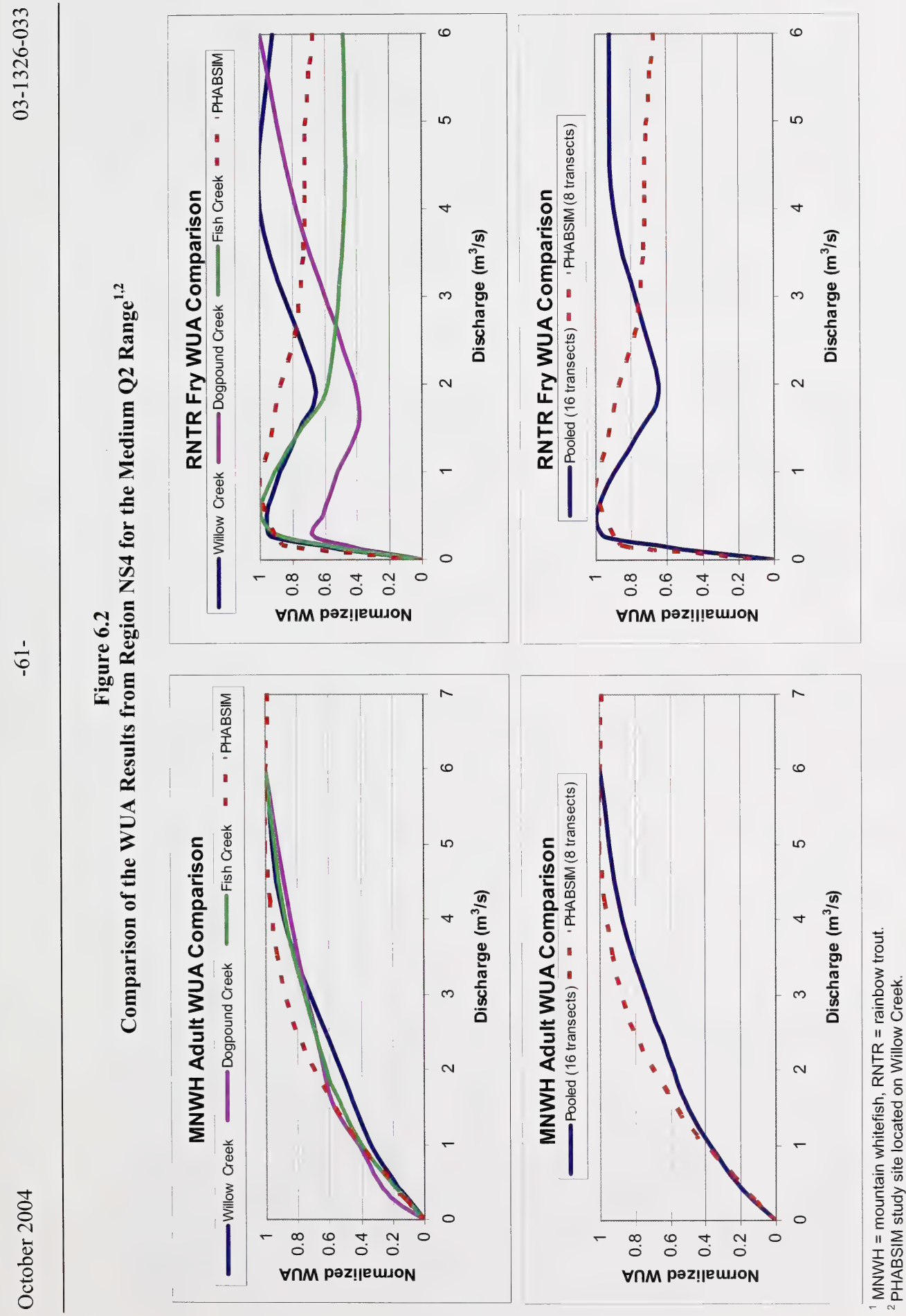


$m$
0
1
0
$n$
$\frac{1}{1}$
$\hat{0}$

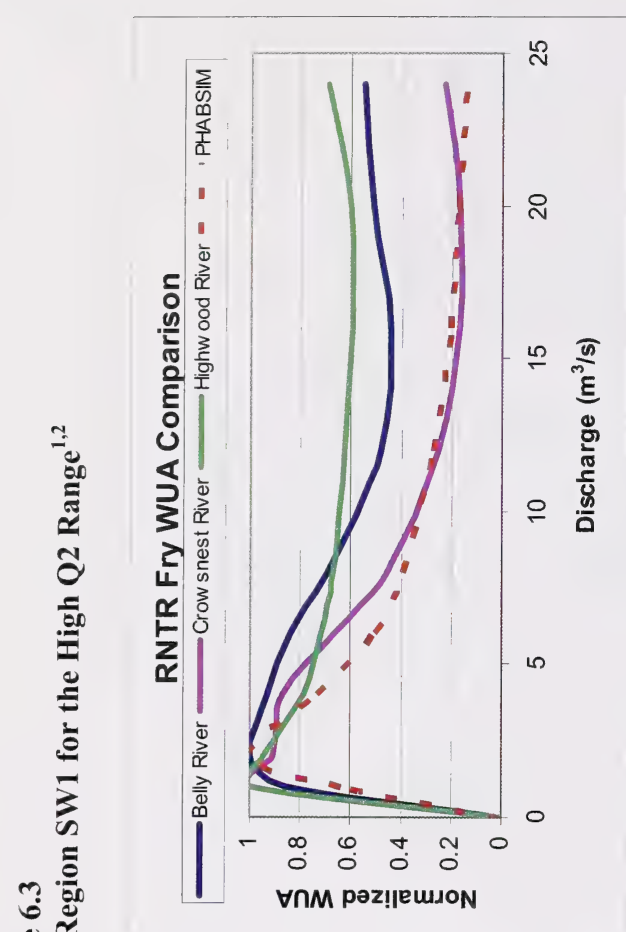

ชู่

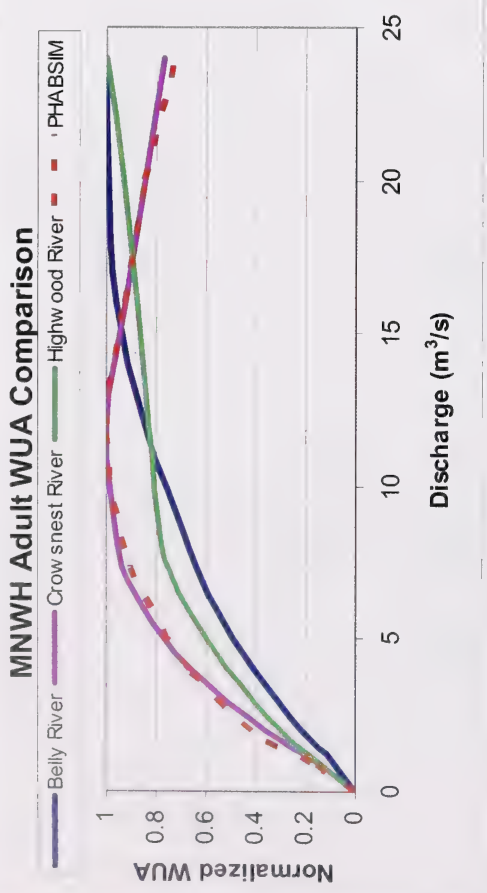

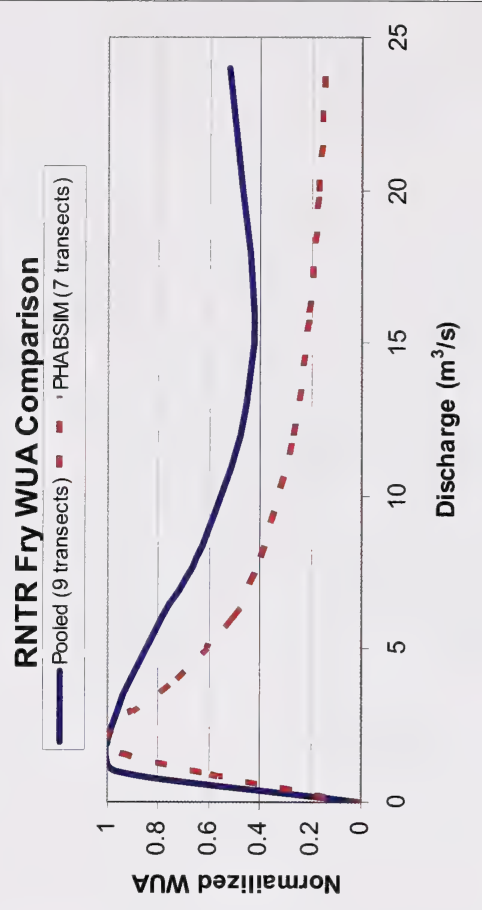

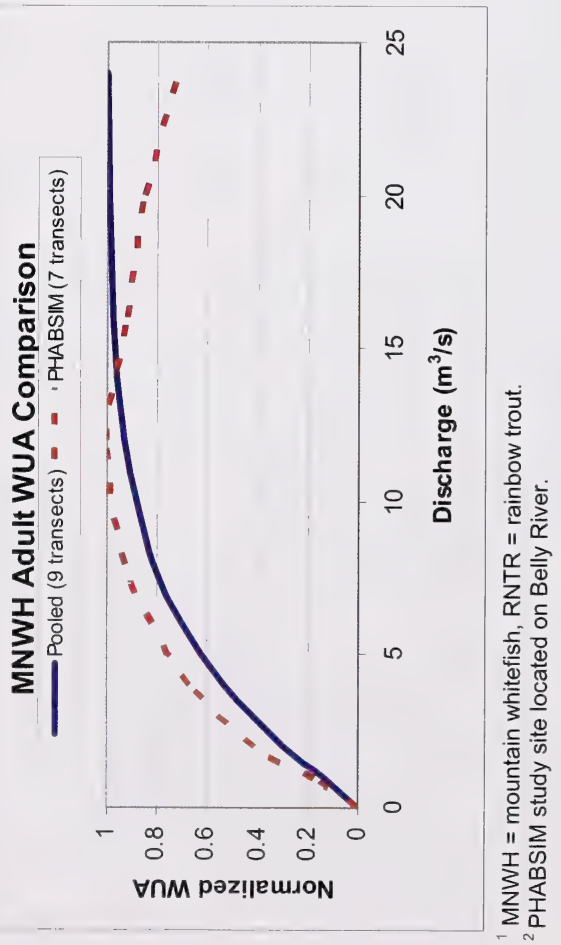


The WUA curves for the individual rapid assessment sites surveyed for this Project show good overall similarity with the PHABSIM data, although there are some divergences in the results. However, when the WUA results from the three rapid assessment sites are pooled (raw WUA values averaged and then normalized), the similarity with the PHABSIM data is apparent upon visual comparison. This result would be expected based on the conclusion that the streams with similar Q2 and Slp within the same hydrologic-geomorphic region are similar, and therefore the resulting WUA curves, which are driven by the hydraulic characteristics of the stream, should also be similar.

These results also indicate that some of the variability observed in the hydraulic comparisons, particularly in NS4, where a north-south division was recommended, may be of less concern from the perspective of creating WUA curves. The reason hydraulic variability may be less of an issue can largely be explained by the bin sizes used to present the flow depth and velocity distributions. For some HSC curves, multiple bins may be grouped together and the variability in hydraulics is masked. Consequently, the observed variability in hydraulics tends to have less significance when the hydraulics are used in developing WUA curves.

Based on the results of the sensitivity or variability analysis presented earlier from the Field Component 3 results, streams over a wide range of Q2 can be grouped together as the same "class" within the same hydrologic-geomorphic region. Streams from NS4 measured in Field Component 2 (Elbow, James and Little Red Deer rivers), Field Component 3 (Reaches 14, 15, 16 and 17) and the PHABSIM site on the Elbow River were compared to test the sensitivity of WUA to changes in Q2. Using readily available drainage characteristic data, the IFN (WUA curve in this case) was transformed using one of the four extrapolation approaches identified by Hardy (2002). Two drainage characteristics were readily available from the GIS data used for the SSRB stream classification: drainage area and Q2. The Q2 discharge has already been determined for the stream reaches in the SSRB by the GIS-based stream classification map developed as a component of this Project. Q2 is a readily available parameter for all stream reaches within the proposed classification scheme and was therefore used to transform the data.

In this comparison, the Q2's of the stream reaches range from 45 to $88 \mathrm{~m}^{3} / \mathrm{s}$, which corresponds to a single Q2 class for NS4 North and covers the transition between two Q2 classes for NS4 South (see pg. 53). The results, with and without transformation are shown in Figure 6.4. Based on visual inspection, the WUA curves are all similar in shape and the results after transformation do not appear to improve the sensitivity of the relationships. This suggests that streams within 
the same Q2 class, and potentially streams in the transition between Q2 classes, would not require transformation based on Q2, and WUA results could be applied directly over a wide range of Q2 values.

Figure 6.4

Comparison of the WUA Results within NS4 Over a Range of Q2 (45 to $\left.88 \mathrm{~m}^{3} / \mathrm{s}\right)$ without Transformation (Top) and with Transformation (Bottom)
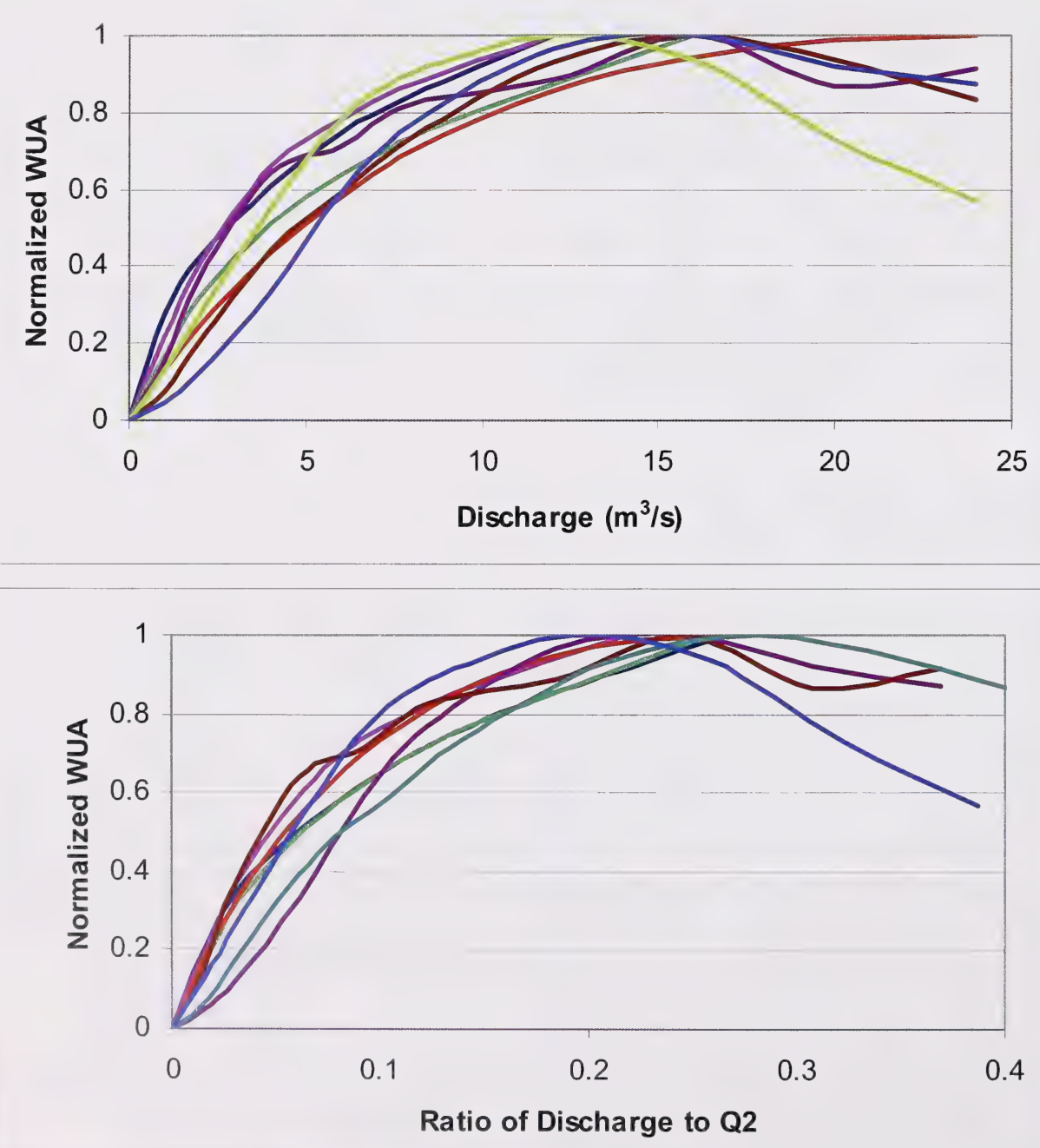
To test the potential for extrapolation further, the WUA results from within a region over a wider range of Q2 discharges was compared. Data from Field Component 2 from the NS4 Medium data set (corresponding to Q2 Class ' 2 ' for NS4 North) and the NS4 High data set (corresponding to Q2 Class ' 3 ' for NS4 North) and the PHABSIM study sites from Willow Creek (NS4 Medium) and Elbow River (NS4 High) were compared. From Figures 6.1 and 6.2, it can be seen that the WUA curves for mountain whitefish adult from the two different classes have similar shapes although the peaks of the curves are different (note the differences in scale between the two figures). The WUA curves from these streams were transformed by again taking the ratio of discharge to Q2 to define a dimensionless $\mathrm{x}$-axis. This test compares two different Q2 classes with a range of Q2's from $24-26 \mathrm{~m}^{3} / \mathrm{s}$ for the Class '2' Q2 category and a range of Q2's from $57-65 \mathrm{~m}^{3} / \mathrm{s}$ for the Class ' 3 ' Q2 category. From visual comparison, the original WUA curves appear very different; however, after the transformation, the WUA curves from the two different Q2 classes become very similar as shown in Figure 6.5.

These result shows promise that the hydraulics, WUA curves, and eventually the IFN rule can be scaled within a region. However, further, more detailed statistical analysis would be warranted to validate this scaling approach. 
Figure 6.5

Comparison of the WUA Results between Q2 Classes within Region NS4 without Transformation (Top) and with Transformation (Bottom)
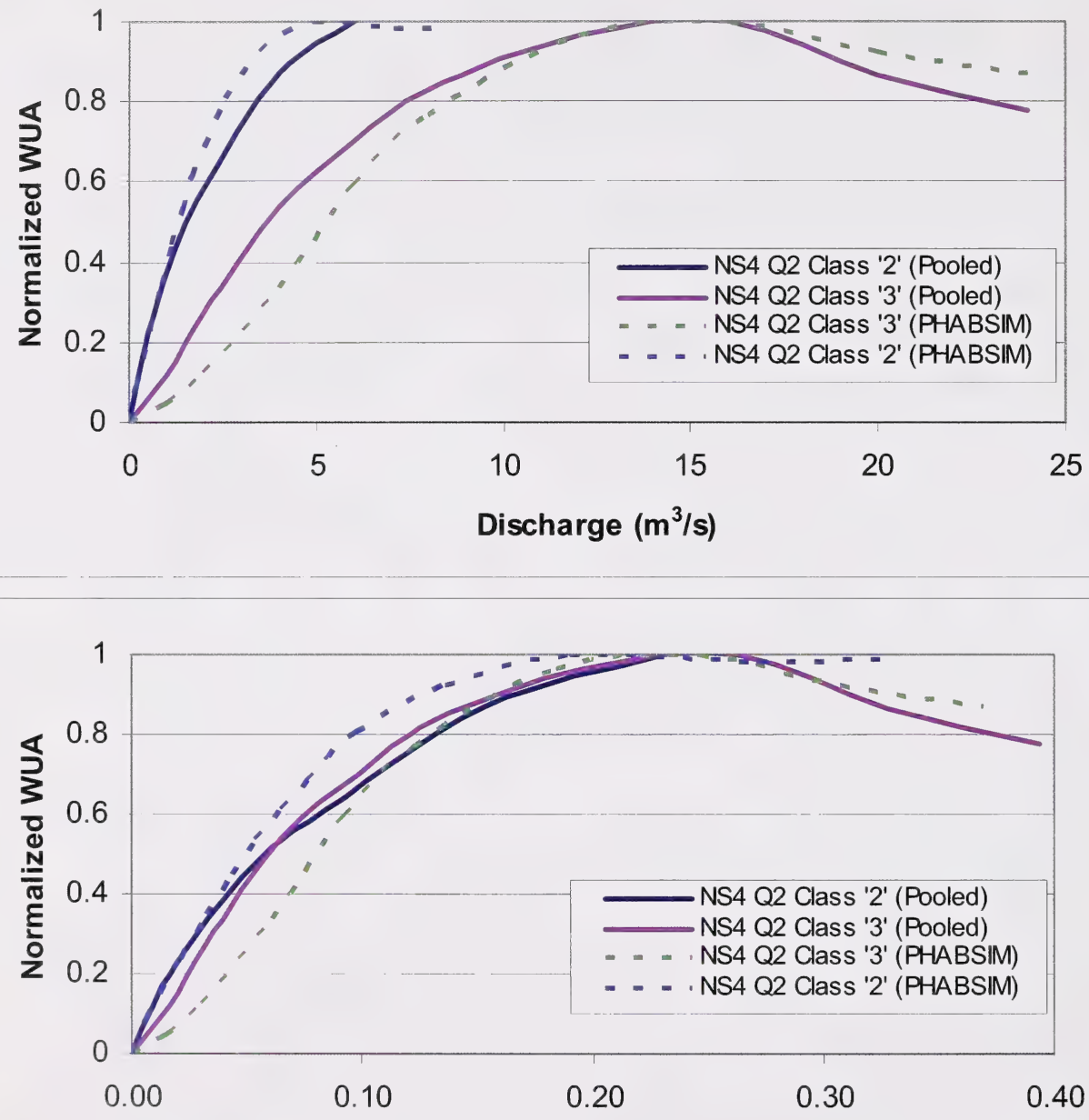

Ratio of Discharge / Q2 


\section{NEXT STEPS OF THE STREAM CLASSIFICATION PROJECT AND FOR DEVELOPMENT OF THE WATER MANAGEMENT TOOLS}

\subsection{Overview of the Project Goals}

AENV is responsible for managing the water resources of the Province of Alberta. AENV is currently developing management tools to comply with new regulatory requirements for protection of the aquatic environment and other fluvial ecosystem components. The overall goal of the AIFNCAP is to develop tools for determining IFNs for small to medium size streams and rivers throughout Alberta.

Using the SSRB as an example, Figure 7.1 shows a schematic of how a stream classification scheme developed under the AIFNCAP would be implemented. A proponent wishing to withdraw water from a particular stream reach would make a request to AENV for an IFN determination. A search of the GIS-database of the stream reaches in the SSRB would then be made to determine the class (Q2-Slp) and hydrologic-geomorphic region of the subject stream reach. Another query would be made to determine whether the IFN data for the given class of streams or rapid assessment data from similar streams are available. There may be a need to do a rapid assessment of the subject stream reach to confirm its hydraulic characteristics. The GISdatabase would then be used to extract the applicable hydraulics or WUA curves from the measured stream reaches in the same class to the subject stream reach. A fully-developed transfer protocol would then be used to transfer the hydraulics or WUA curves to the subject stream reach. It is expected that the IFN or hydraulic database would be reviewed as more data are available and added to continually improve the predictive capacity of this tool.

The Phase I work of this Project was the first step in moving towards achieving the AIFNCAP's goal. A number of steps are still required to reach the overall AIFNCAP's goal in the SSRB and ultimately to extend the tool to the rest of the province. Phase II of the project for the SSRB would include the following:

- Collection of hydraulic data, using the rapid assessment approach supplemented with detailed 2-D hydraulic assessment at select sites in each hydrologic-geomorphic region, for streams of all classes within all hydrologic-geomorphic regions of the 
SSRB. This would be a time-consuming undertaking. It is recommended that areas of the SSRB with pressing issues and high water demands be targeted first.

- Development of habitat suitability curves. Existing HSC are available for most target management species in the SSRB; however addition development may be required. This was outside the scope of the present study.

- Development of a GIS-interface to facilitate query of the IFN and stream database.

Figure 7.1

A Schematic for Applying the Stream Classification Scheme

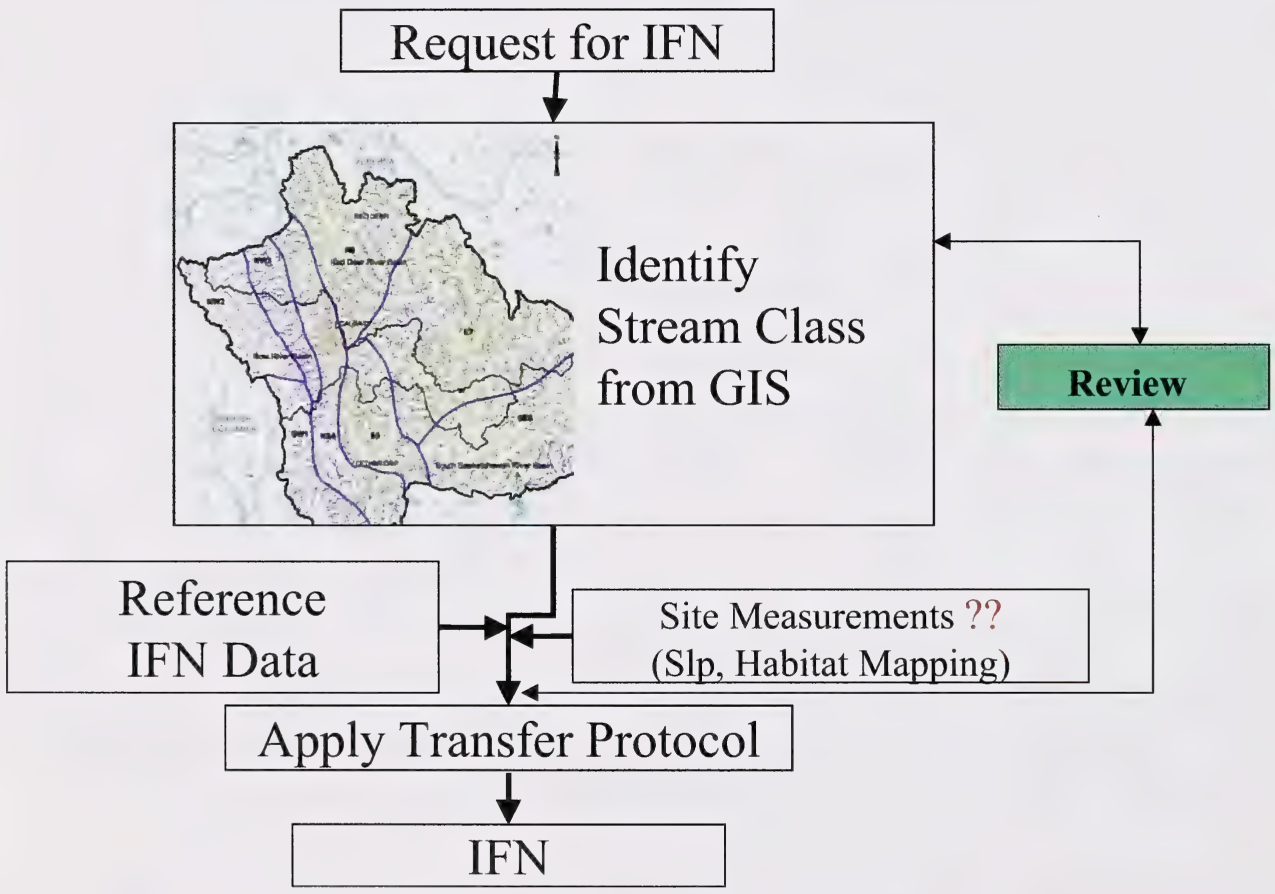

Extension of the tool developed for the SSRB to the other basins in Alberta would require similar steps. The first step would be hydrologic-geomorphic regionalization and stream classification. The scope of the validation of the stream classification approach for other regions of Alberta may be somewhat less extensive than that done for the SSRB. Nevertheless, there are additional issues, such as availability of recorded flow data, appropriate GIS-based hydrography, digital elevation models and development of fisheries management objectives that would require specific attention during the extension. 
In addition, the province is promoting an ecosystem approach to managing the aquatic resources. Therefore, it is important to assess the possibility of using a similar stream classification scheme for other aquatic components, such as riparian habitat and channel morphology.

\subsection{Applying the Stream Classification Method to the Entire Province}

Development of the IFN Classification tool for the entire province would require an extension of the classification method tested and developed for the SSRB to the other river basins in the province. It is recommended that the protocol for the initial stream classification (Golder 2001) be followed to develop the initial regional boundaries. Data availability across the province will vary and some preliminary data compilation may be required in order to apply the classification method in some parts of the province. The limiting factors are likely to be the availability of suitable DEM and other GIS data (such as properly structured stream hydrography) for the entire province needed to derive Q2, stream slope and other basin descriptors. The work done with the GIS layers provided by AENV for the SSRB indicates that a significant amount of pre-processing would be required prior to use. The elevation values attached to the stream hydrography differed significantly, particularly in mountainous regions, from those extracted from the DEM. It is important that the province make an inventory of available GIS layers and the quality of their attributes prior to application of the stream classification method in other areas of the province.

Another issue of concern is the impact of land use practices on stream morphologic characteristics. The survey of sites carried out as part of this study highlighted this issue. A number of sites were not included in the final survey because of beaver dams, slumping banks, disturbed river beds, etc.

Limited hydrometric data, either in terms of spatial coverage or length of record, could also be an issue. Additional analysis would likely be required to fill in some of the data gaps. Development of the stream classification for the province could then proceed and be refined as data become available. 


\subsection{Building the IFN Database}

Populating the stream hydraulic and IFN database with the site-specific data is needed for completing development of the classification tool and for extrapolation from measured to unmeasured streams. A number of technical challenges were encountered during the current phase in modelling the stream hydraulics based on the data collected using the rapid assessment approach. It is recommended that the future field data collection program consider the following:

- The rapid assessment approach includes an initial task of a rapid site reconnaissance to visually examine the similarity of the comparable sites to ensure that the selected sites meet with the data collection expectation and to identify any obvious discrepancy between the expectation and the site conditions. This would allow a revision or refinement of the data collection program if required, including modifying the site selection.

- The rapid assessment protocol for each site includes a rapid measurement of the water surface profile along the selected stream reach. This additional information, which can be collected quickly, can be used to assess the local variation in the energy slope, to assist more accurate selection of the representative transects for collecting the detailed hydraulic information than simple visual inspection of the habitat types, and to supply additional information for refining characterization of the habitat types along the stream reach.

- Transects should be placed judiciously so that they can represent the general hydraulic conditions for each habitat type. Transects that fall in dead flow zones, flow circulation zones, sharp bends or nearby downstream obstructions within a habitat type and that are not representative of the habitat should be avoided.

- Populating the hydraulic and IFN database for each hydrologic-geomorphic region includes collection of data using the rapid assessment protocol for majority of the sites to ensure program efficiency, and collection of detailed bathymetric, substrate and hydraulic information suitable for calibrating a 2-dimensional hydraulic model for a number of select and representative stream reaches. The detailed 2-D data collection is necessary to assess the expected ranges of errors associated with the rapid assessment approach, and to confirm the suitability of using the available rapid 
assessment data for a reasonably accurate extrapolation of the INF from measured to unmeasured sites.

- Once Fisheries Management Objectives are in place for each hydrologic-geomorphic region in the province, field collection of habitat use data and development of regional HSC curves by expert workshop is necessary.

It should be recognized that this intermediate level of effort by applying the stream classification approach for determining IFNs (compared to a full PHABSIM IFN determination) introduces some degrees of uncertainty and imprecision. The results and findings presented in this report, including the comparisons of hydraulics and WUA results, show good degrees of similarity among comparable sites. The variability observed in the results of comparable sites is to be expected.

However, it should be noted that the IFN developed for an unmeasured stream, based on this stream classification approach, may be slightly higher, slightly lower, or about the same as it would be if a site-specific study was conducted. A similar conclusion has been made in the other projects to develop an extrapolation approach to determine IFN values for unmeasured sites (Lamouroux and Carpa 2002, Lamouroux and Souchon 2002). This loss in site-specific precision is compensated by a gain of efficiency in both time and money. However, this consequence of a significant error in IFN specification using this approach should be investigated as more data become available and comparative studies can be undertaken.

When considering locations for detailed study in the next phase of the Project, it may be prudent to select sites that are under increasing allocation pressure and where a site-specific study may be necessary in the future. A strategic approach to study site selection would serve to advance the application of the classification system as well as providing site-specific detail in areas where increased water demand pressure is anticipated. 


\subsection{Other Ecosystem Components}

\subsubsection{General}

During the initial development of the "Alberta Method" (Anonymous 1995, DeVries et al. 1999), the main approach used in Alberta to develop IFN recommendations at that time was based on fish habitat assessments. Since this Project was initiated, science has advanced to incorporate multiple ecosystem components, and include the full range of natural flow variability in an IFN study framework (Annear et al. 2002). The most recent application of a site-specific IFN in Alberta applied this approach and developed an integrated ecosystem IFN that accounted for fish habitat, water quality, riparian ecosystems and channel maintenance flows (Clipperton et al. 2003). The continuing development of the IFN Classification tool should include considerations to incorporate other ecosystem components where applicable.

\subsubsection{Riparian Ecosystems}

Consideration of riparian ecosystems has been accounted for to some extent in the recommended stream classification approach for Alberta, because the existing ecoregion boundaries were considered in developing the hydromorphic-geomorphic regions for the IFN stream classification. The ecoregion boundaries take into account differences in riparian communities throughout the province. However, riparian site assessment is still necessary to allow for estimation of riparian flows.

In applying the current approach to riparian ecosystems, minor additions to the detailed and rapid assessment field protocols would provide sufficient data for a preliminary riparian assessment. Measurements of bankfull stages have already been included in the current field protocols and surveying the extent of the riparian zone and conducting a riparian site assessment would only require a minimal amount of additional efforts. These additional data would allow for a cursory evaluation of riparian flows similar to the procedure used elsewhere in Alberta (Clipperton et al. 2003). 


\subsubsection{Channel Maintenance}

The protocol developed for defining channel maintenance flows by using the Shields equation is described in Clipperton et al. (2003). It would be relatively straightforward to apply this protocol to the current stream classification approach with little additional effort. Measurements of bankfull elevation, stream slope and substrate material are already a part of the field protocols. The hydrologic-geomorphic regionalization should result in streams within a region having similar hydraulic characteristics, as supported by the results of this study. Extrapolation of channel morphology results within a region, although not investigated in this study, should be possible based on the findings of similar hydraulic conditions between comparable sites within a region.

\subsubsection{Water Quality}

The water quality approach, as outlined in Clipperton et al. (2003), may have limited applicability within the current stream classification approach. The water quality IFN results were based on models that use site-specific inputs to determine flow thresholds where the loadings in the system result in water quality guideline criteria not being met. The type of data used in the Clipperton et al. (2003) approach cannot be regionalized since point-source inputs occur at any point within a basin.

However, there may be some potential for a regional water quality based-approach to be incorporated into the current stream classification system. The primary variables often considered for IFN studies (temperature and dissolved oxygen) have spatial trends that may have already be captured by the hydrologic-geomorphic regionalization. The streams in the south have water quality trends that are different from the streams in the north. There are differences from west to east as well.

Using GIS as a classification platform, other parameters, such as municipality locations, could be accounted for in the final analysis as could licensed loadings from these sources. Under certain circumstances, specific water quality studies may still be warranted. However, identifying general water quality trends at a resolution that would match the intermediate level of effort desired from the present IFN Classification approach should be possible. 


\subsection{Extrapolation Protocol}

This Phase I study included a preliminary assessment of extrapolating IFN results within a hydrologic-geomorphic region. Defining an extrapolation relationship that can be used for each region will require additional efforts and should include a statistical evaluation to define the parameter that best accounts for the variability amongst sites. Multiple approaches are possible, and in some respects, it may depend on the final format required for the IFN. To apply the protocols outlined in Clipperton et al. (2003), a complete WUA curve is required in order to conduct habitat time series assessments and not just the peak of the curve defined from a regression equation as has been done in other studies. However, a time series approach would also require long-term hydrologic data that would not be available at most stream reaches in the province.

Nicolas Lamouroux and his colleagues in France have developed a model to predict habitat change at different flows(e.g., Lamouroux and Carpa 2002), although an extension of this approach to other regions has not been tested. Results from continuing work on the Nooksack Basin by Thom Hardy and his colleagues on extrapolation approaches (e.g., Saraeva and Hardy 2004) will also be useful in defining options to be tested for the Alberta approach. Showing similarity of hydraulic characteristics and IFN results is only the first step in this process. It is still necessary to identify how an IFN will be defined using this protocol. This may limit some of the options available for extrapolation. An extrapolation workshop, similar to that conducted for the Nooksack basin in Washington State, may help to define options for determining IFNs on unmeasured streams.

\subsection{Preliminary Assessment of Costs for Implementing the Recommended Stream Classification for Alberta}

\subsubsection{Previous Cost Estimates}

DeVries et al. (1999) produced a cost estimate for implementing a stream classification approach in Alberta based on experience in Idaho. The cost estimate is now dated both in terms of the final approach being considered for Alberta and the fee schedule used. In 1999, the cost estimate for the province-wide implementation was approximately 10 million dollars. However, the fee schedule to calculate this total was based on rates that had been previously used by Reiser and DeVries (1996) and eight years out of date. The hourly rate for senior and junior personnel used 
in the original cost estimate was $\$ 50$ and $\$ 30$ respectively. These rates may have represented internal salary costs to conduct the project and were not intended to be "consultant" dollars. Based on rates representative of current day consulting fees of $\$ 125 /$ hour for a senior person and $\$ 75 /$ hour for a junior person, the original cost estimate provided by DeVries et al. (1999) should be increased by a factor of 2.5 . This would bring the original cost estimate provided by $\mathrm{R} 2$ to \$25 million for classifying streams for the entire province.

The approach currently recommended for Alberta is different than that proposed by DeVries et al. (1999). The initial data collection conducted to validate the recommended approach has provided a basis for estimating the level of effort required to complete the classification for the SSRB and ultimately the entire province.

\subsubsection{Implementation for SSRB}

The SSRB is a watershed with significant pressures on its water resources for agricultural, municipal and industrial uses. This Project was initiated partly in response to address instream water requirements in the face of increasing water demands from the small to medium-sized streams. Therefore, the SSRB is one of the priority watersheds in Alberta for fully implementing the recommended stream classification approach.

Table 7.1 shows the estimated cost for implementing the recommended stream classification methodology to the SSRB. The costs presented in Table 7.1 do not include those for addressing ecosystem components other than instream flows. This is an exercise that should be undertaken outside of the scope of this project. The assumptions in the costs estimation specific to the SSRB include the following:

- About 10 stream classes would represent most of the streams within a given region in the SSRB based on the stream classification task carried out for this Project to date.

- The field effort to collect hydraulic data would involve five detailed River2D study sites within each of the nine hydrologic-geomorphic regions of the SSRB and the collection of 30 rapid assessment sites per hydrologic-geomorphic region. This would be equivalent to least three rapid assessment sites for each Q2-Slp class within each region. 
Table 7.1

Cost Estimate for Completing the AIFNCAP for the SSRB

\begin{tabular}{|c|c|c|c|}
\hline Task Description and Cost Items & $\begin{array}{l}\text { Costs per } \\
\text { Hydrologic- } \\
\text { Geomorphic } \\
\text { Region }\end{array}$ & $\begin{array}{l}\text { Other Unit } \\
\text { Costs }\end{array}$ & $\begin{array}{l}\text { Costs for the } \\
9 \text { regions of } \\
\text { the SSRB }\end{array}$ \\
\hline \multicolumn{4}{|l|}{ 1. Stream Classification } \\
\hline Database Management & & & Completed \\
\hline Regionalization & & & Completed \\
\hline Class Delineation Using GIS & & & Completed \\
\hline Project Management and QA/QC & & & Completed \\
\hline \multicolumn{4}{|c|}{ Assume all 9 hydrologic-geomorphic regions for the SSRB included for classification } \\
\hline \multicolumn{4}{|l|}{ 2. Collect Hydraulic Field Data } \\
\hline $\begin{array}{l}\text { Rapid Assessment (30 sites/h-g region @ } \\
\$ 2000 / \text { site) }\end{array}$ & $\$ 60,000$ & & \\
\hline $\begin{array}{l}\text { River2D Site (5 sites/h-g region @ } \\
\$ 10,000 / \text { site) }\end{array}$ & $\$ 50,000$ & & \\
\hline $\begin{array}{l}\text { Project Management and QA/QC ( } 3 \\
\text { hours/site) }\end{array}$ & $\$ 13,125$ & & \\
\hline $\begin{array}{l}\text { Cost (minus cost for data at } \sim 30 \text { rapid } \\
\text { assessment sites surveyed for this project } \sim \\
\$ 60,000 \text { for SSRB) }\end{array}$ & $\$ 123,125$ & & $\$ 1,048,000$ \\
\hline \multicolumn{4}{|l|}{ 3. Data Entry and Analysis } \\
\hline $\begin{array}{l}\text { Rapid Assessment (30 sites/h-g region @ } \\
\$ 1500 / \text { site }\end{array}$ & $\$ 45,000$ & & \\
\hline $\begin{array}{l}\text { River2D Site (5 sites/h-g region @ } \\
\$ 5,000 / \text { site) }\end{array}$ & $\$ 25,000$ & & \\
\hline $\begin{array}{l}\text { Project Management and QA/QC ( } 2 \\
\text { hours/site) }\end{array}$ & $\$ 8,750$ & & \\
\hline $\begin{array}{l}\text { Cost (minus cost for analysis at } \sim 30 \text { rapid } \\
\text { assessment sites surveyed for this project } ~ \\
\$ 60,000 \text { for SSRB) }\end{array}$ & $\$ 78,750$ & & $\$ 649,000$ \\
\hline \multicolumn{4}{|l|}{ 4. Habitat Suitability Criteria Development } \\
\hline $\begin{array}{l}\text { Collect Baseline HSC Data ( } 2 \text { weeks } / \mathrm{h}-\mathrm{g} \\
\text { region) }\end{array}$ & & $\$ 40,000$ & \\
\hline Expert Workshop (per major river basin) & & $\$ 25,000$ & \\
\hline Cost & & & $\$ 65,000$ \\
\hline \multicolumn{4}{|l|}{ 5. Flow Extrapolation Tool Development } \\
\hline $\begin{array}{l}\text { Cost based on updated (factor of 2.5) R2 } \\
\text { Resource estimate }\end{array}$ & & $\$ 100,000$ & $\$ 100,000$ \\
\hline \multicolumn{4}{|l|}{ 6. Flow Recommendations } \\
\hline $\begin{array}{l}\text { Cost based on updated (factor of } 2.5 \text { ) R2 } \\
\text { Resource estimate }\end{array}$ & & $\$ 75,000$ & $\$ 75,000$ \\
\hline \multicolumn{3}{|c|}{ Total Cost } & $\$ 1,937,000$ \\
\hline
\end{tabular}


- About 60 sites were surveyed during this phase of the Project and the data at 30 of these sites were assumed to be suitable for incorporation into the SSRB's database. The cost for surveying these sites and analyzing the data is equivalent to that of one hydrologic-geomorphic regions (10 classes $\mathrm{x} 3$ sites/class $\mathrm{x} 1$ region).

- The cost for developing HSC for the SSRB is lower compared to similar work in the rest of the province since HSC data are available and expert workshops have already been conducted for many species found within the SSRB.

- The cost for surveying the sites in the SSRB is lower compared to similar work in the rest of the province because of the relatively easy access to sites in the SSRB.

It is estimated that $\$ 1,937,000$ (in 2004-dollars) would be required to fully implement the recommended stream classification methodology for the small to medium-sized streams in the SSRB. This cost estimate for the SSRB has a much higher level of certainty than that extrapolated to the entire province because most of the project work conducted to date has been on the SSRB. This provides a good basis for the cost estimate specific to the SSRB.

\subsubsection{Implementation for the Entire Province}

A cost estimate is provided in Table 7.2 for extending the recommended stream classification methodology to the entire province. The costs presented in Table 7.2 do not include those for addressing ecosystem components other than instream flows. This is an exercise that should be undertaken outside of the scope of this project. The costs were developed based on the assumptions that there would be approximately 32 hydrologic-geomorphic regions (including the 9 regions for the SSRB) within Alberta and, on average, there will be 10 Q2-Slp classes within each region. The estimate for the SSRB is based on extensive GIS analysis. However, the same assumption for the rest of the province introduces some uncertainty in the cost estimate because of the uncertainty in stream characteristics in other regions of the province. Some regions may have more classes and others may have a lower number of stream classes. However, for the purpose of providing a rough estimate of costs to complete the Project, each potential hydrologic-geomorphic region was treated equally. 
Table 7.2

Cost Estimate for Completing the AIFNCAP for the Province of Alberta

\begin{tabular}{|c|c|c|c|}
\hline Task Description and Cost Items & $\begin{array}{l}\text { Costs per } \\
\text { Hydrologic- } \\
\text { Geomorphic } \\
\text { Region }\end{array}$ & $\begin{array}{l}\text { Other Unit } \\
\text { Costs }\end{array}$ & $\begin{array}{l}\text { Updated } \\
\text { Costs for } \\
\text { Entire } \\
\text { Province } \\
\end{array}$ \\
\hline \multicolumn{4}{|l|}{ 1. Extend Stream Classification to Province } \\
\hline \begin{tabular}{l|l} 
& Database Management \\
\end{tabular} & $\$ 3,000$ & & \\
\hline Regionalization & $\$ 22,500$ & & \\
\hline Class Delineation Using GIS & $\$ 12,000$ & & \\
\hline Project Management and QA/QC & $\$ 2,000$ & & \\
\hline $\begin{array}{l}\text { Cost: assume } 23 \text { additional regions } \\
\text { (9 regions in SSRB complete) }\end{array}$ & & & $\$ 908,500$ \\
\hline \multicolumn{4}{|l|}{ 2. Collect Hydraulic Field Data } \\
\hline \begin{tabular}{|l|l} 
& $\begin{array}{l}\text { Rapid Assessment (30 sites/h-g region @ } \\
\$ 3000 / \text { site) }\end{array}$ \\
\end{tabular} & $\$ 90,000$ & & \\
\hline $\begin{array}{l}\text { River2D Site (5 sites/h-g region @ } \\
\$ 12,000 / \text { site) }\end{array}$ & $\$ 60,000$ & & \\
\hline $\begin{array}{l}\text { Project Management and QA/QC (3 } \\
\text { hours/site) }\end{array}$ & $\$ 13,125$ & & \\
\hline Cost: 32 regions & $\$ 163,125$ & & $\$ 5,220,000$ \\
\hline \multicolumn{4}{|l|}{ 3. Data Entry and Analysis } \\
\hline \begin{tabular}{l|l} 
& $\begin{array}{l}\text { Rapid Assessment (30 sites/h-g region @ } \\
\$ 1500 / \text { site }\end{array}$ \\
\end{tabular} & $\$ 45,000$ & & \\
\hline $\begin{array}{l}\text { River2D Site (5 sites/h-g region @ } \\
\$ 5,000 / \text { site) }\end{array}$ & $\$ 25,000$ & & \\
\hline $\begin{array}{l}\text { Project Management and QA/QC } \\
\text { (3 hours/site) }\end{array}$ & $\$ 13,125$ & & \\
\hline Cost: 32 regions & $\$ 83,125$ & & $\$ 2,660,000$ \\
\hline \multicolumn{4}{|l|}{ 4. Habitat Suitability Criteria Development } \\
\hline \begin{tabular}{l|l|} 
& $\begin{array}{l}\text { Compile Existing Fisheries Data into FMIS } \\
\text { (8 person weeks) }\end{array}$ \\
\end{tabular} & $\$ 30,000$ & & \\
\hline $\begin{array}{l}\text { Develop Fisheries Management Objectives } \\
\text { (Internal) }\end{array}$ & $\$-$ & & \\
\hline $\begin{array}{l}\text { Collect Baseline HSC Data ( } 2 \text { weeks/h-g } \\
\text { region) }\end{array}$ & $\$ 20,000$ & & \\
\hline Project Management and QA/QC & $\$ 2,000$ & & \\
\hline Expert Workshop (per major river basin) & & $\$ 25,000$ & \\
\hline \begin{tabular}{|l|l|} 
& Assume 32 regions $\& 6$ Workshops \\
\end{tabular} & & & $\$ 1,814,000$ \\
\hline \multicolumn{4}{|l|}{ 5. Flow Extrapolation Tool Development } \\
\hline \begin{tabular}{|l|l} 
& Expert Workshop (province wide) \\
\end{tabular} & & $\$ 50,000$ & \\
\hline $\begin{array}{l}\text { Cost update from R2 Resource estimate } \\
\text { (Factor of } 2.5 \text { ) }\end{array}$ & & $\$ 1,212,000$ & \\
\hline & & & $\$ 1,262,000$ \\
\hline \multicolumn{4}{|l|}{ 6. Flow Recommendations } \\
\hline \begin{tabular}{|l|l|} 
Cost update from R2 Resource estimate \\
(Factor of 2.5)
\end{tabular} & & $\$ 584,000$ & \\
\hline & & & $\$ 584,000$ \\
\hline & & Total Cost & $\$ 12,450,000$ \\
\hline
\end{tabular}


Cost extrapolation to the rest of the province was made based on the level of effort required to complete the classification for the SSRB and factoring in possible difficulties in site access in other regions, lack of hydrometric and other data for regionalization, and generally higher costs for more remote areas. An assessment of the available GIS data for the province was not conducted. However, it was assumed that some database development would be required to fill in data gaps across the province.

The development of the Fisheries Management Objectives was assumed to be a task done internally within ASRD. Effort has been indicated (eight person-weeks per hydrologicgeomorphic region) to assist with the input of existing fisheries data into the Fisheries Management Information System. Development of HSC data will require some data collection within each hydrologic-geomorphic region with a series of expert workshops held to finalize the HSC curves to be used with a classification approach. The costs for completing the extrapolation and IFN development was based on the time estimates originally produced by $\mathrm{R} 2$ and updated to current rates by multiplying the cost by a factor of 2.5 .

It is estimated that about $\$ 12,450,000$ (in 2004-dollars) would be required to fully implement the recommended stream classification methodology for the small to medium-sized streams in the entire province (including the SSRB). The total expenditure for a province-wide implementation of the recommended stream classification methodology may however be spread over a number of years and may be directed towards priority areas first.

The total cost presented in Table 7.2 reflects the uncertainties inherent in applying the recommended approach to other areas of the province which may have fewer stream sites with long periods of hydrometric and climatic data, where the hydrology may not be as well known as that of the SSRB, and access to sites may pose difficulties, among other uncertainties. Nevertheless, the current cost estimate ( $\$ 12.5$ million) for implementing the recommended approach for Alberta is about $50 \%$ less than the cost ( $\$ 25$ million in 2004 consulting dollars) estimated by $\mathrm{R} 2$. 


\section{CONCLUSIONS AND RECOMMENDATIONS}

\subsection{Conclusions}

The results of this Phase I study support the following conclusions:

1. The proposed stream classification method is reasonably supported based on the available hydraulic data for the SSRB, comparisons of the reach-averaged cell flow velocities and depths, and visual examination of the distributions of the cell flow velocities and depths. More detailed statistical analysis is recommended for Phase II when each region will be populated with additional data. Such verification is desirable to vigorously test the method and to define the error bounds and degrees of similarity more accurately.

2. The stream reaches of similar Q2 and Slp in the same hydrologic-geomorphic region have been shown to have similar reach average cell flow velocities and depths as well as similar distributions of cell flow velocities and depths. Although the sample sizes of the available sites were insufficient for rigorous statistical testing, comparisons of the reachaveraged cell flow velocities and depths show that the hydraulics of comparable sites generally vary between $10 \%$ and $30 \%$ of the sample means, about $90 \%$ of the time.

3. Within a given hydrologic-geomorphic region, the Q2 and Slp parameters are appropriate for stream classification and are therefore appropriate for the transfer of hydraulics from measured to unmeasured streams.

4. The preliminary Q2 and Slp ranges for stream classification were suitable for initial testing. The available data show that the ranges for each class should be refined at the lower Q2 ranges for the foothills (NS4) and the lower Q2 and Slp ranges and prairie (N6) regions. Different regions may have different threshold values for grouping the stream reaches into various classes, but the general approach of classification based on ranges of Q2's and Slp's is the same for all regions. The proposed threshold values will need to be updated when more data are available for each region. It is not expected that the total number of Q2 or Slp classes would largely exceed the five classes that were initially 
proposed for the NS4 and N6 regions, because these two regions have few streams with very high Q2 and Slp.

5. The weighted useable area (WUA) curves for the stream reaches with similar Q2 and Slp within the same hydrologic-geomorphic region are similar to the WUA curves developed from the detailed Physical Habitat Simulation (PHABSIM) studies. This suggests that the observed variability in the distributions of the cell flow depths and velocities of the comparable, rapid assessment sites may not be a concern when predicting WUA curves within a region.

6. The results of a preliminary assessment of the protocols for transferring IFNs suggest that the WUA curves of the stream reaches within the same class are similar. The proposed stream classification scheme to group hydraulically similar stream reaches based on Q2 and Slp ranges, is therefore appropriate for general application.

7. The WUA curves from the stream reaches belonging to different classes with the same hydrologic-geomorphic region appear very different. However, after transformation based on Q2, the WUA curves from two different Q2 classes become very similar. Therefore, a basin or streamflow parameter, such as Q2, may be used to scale IFN data within the same hydrologic-geomorphic region from measured sites to unmeasured sites.

8. The results of this Phase I study have shown that the hydraulics, WUA curves, and eventually the IFN can be transferred between stream reaches of similar classes within the same hydrologic-geomorphic region. The analysis shows a potential for scaling between adjacent stream classes within the same region. However, this would be tested and formulated in Phase II by more detailed statistical analysis when each region will be populated with additional data. An expert workshop should be used to help define potential extrapolation protocols.

9. The proposed stream classification method is recommended for the transfer of IFNs from measured to unmeasured sites in those cases where intermediate levels of effort required for determining IFNs would otherwise have been used. 
10. It is estimated that about $\$ 1,937,000$ (in 2004-dollars) would be required to fully implement the recommended stream classification methodology for small to mediumsized streams in the SSRB. This cost estimate is based on the experience gained during this phase of the Project in the SSRB. The cost estimate for implementing the approach to the entire province (including the SSRB) is about $\$ 12.5$ million (in 2004-dollars), compared to about $\$ 25$ million (in 2004 consulting dollars) estimated by R2. The new cost estimate for the entire province may still be an approximation because of some uncertainties associated with extending the approach and extrapolating the cost estimate for the SSRB to relatively lesser studied areas of the province.

\subsection{Recommendations}

The following recommendations are made based on the results of this Phase I study:

1. The proposed stream classification method, based on a hydrologic-geomorphic regionalization and classification by Q2 and Slp, should be adopted as the basis for deriving IFNs in Alberta to help manage future water allocations while meeting the requirements of the Water Act for the protection of the aquatic ecosystem.

2. Phase II of the IFN classification program should include a strategic sampling program using a combination of rapid assessment methods for most sites and a detailed data collection approach suitable for 2D hydraulic modelling analysis for select sites. Such a sampling program should begin with the SSRB and could be expanded as required to include other river basins in the province, with priorities given to the regions with pressing or emerging water demand issues.

3. The rapid assessment data collection protocols should include site reconnaissance and measurements of water surface profiles. Transects should be placed selectively so that they can represent the average hydraulic conditions for each habitat type. Transects that fall in dead flow zones, flow circulation zones, sharp bends or nearby downstream obstructions within a habitat type and that are not representative of the hydraulic conditions of the habitat type, should be avoided. 
4. As no protocols are readily available, an expert workshop should be held to investigate options for extrapolating IFN results that would be best suited to the data requirements for developing an IFN in Alberta.

5. Fisheries management objectives, development of habitat suitability criteria and protocols for addressing other ecosystem components should begin as soon as possible for all regions targeted for the initial data collection effort such that an IFN can be developed that accounts for regional management objectives and would provide for ecosystem protection.

6. The province is promoting an ecosystem approach to managing the aquatic resources. The proposed classification approach would appear to be suitable for incorporation of other ecosystem IFN components, particularly riparian ecosystems and channel maintenance flows, with minimal additional field effort than identified for the fisheries component. Development of a rapid assessment protocol for each different ecosystem component of interest was outside of the current scope of work. 


\section{GOLDER ASSOCIATES LTD.}

Report Prepared by:

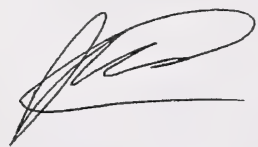

Anil Beersing, Ph.D., P.Eng.

Project Manager, Senior Water Resources Engineer

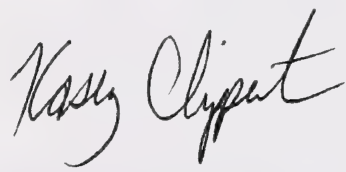

Kasey Clipperton, M.E.Des.

Fisheries Biologist
Report Reviewed by:

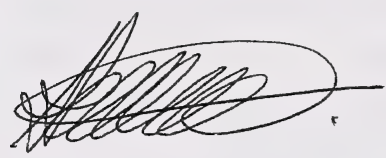

Les Sawatsky, M.Sc., P.Eng.

Principal, Project Director

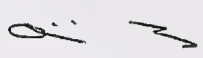

Dejiang Long, Ph.D., P.Eng.

Principal, Water Resources Engineering

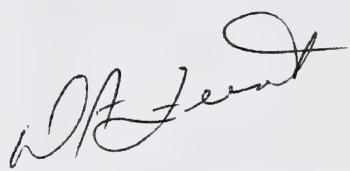

David A. Fernet, M.Sc., P.Biol.

Principal, Senior Fisheries Scientist 


\section{REFERENCES}

Annear, T.C., I. Chisholm, H. Beecher, A. Locke, and 12 other authors. 2002. Instream flows for riverine resource stewardship. Published by the Instream Flow Council, Cheyenne, WY.02.

Anonymous. 1995. Development of a method for Recommending Instream Flows for Fishes in Alberta: The Alberta Method (Draft). Prepared for Alberta Environmental Protection, Fish and Wildlife Service.

Alberta Environment (AENV). 2000. http://www3.gov.ab.ca/env/water/basins/BasinForm.cfm

Alberta Environment Protection. 1998. South Saskatchewan River Basin Historical Weekly Natural Flows 1912 to 1995. Prepared by Water Science Branch.

Bietz, B. F., J. A. Martin, and J. Englert. 1985. Instream Flow Needs for Fish in Alberta: A User's Guide to Assessment Methods. IEC Beak Consultants Ltd. Prepared for Alberta Energy and Natural Resources, Fish and Wildlife Division.

Bjornson, C.P. and D.A. Fernet. 1989. Instream flow needs investigations of the St. Mary, Belly and Waterton rivers, 1988. Prepared for Habitat Branch, Fish and Wildlife Division, Edmonton, AB. Prepared by EMA, Calgary. 102p. +App.

Bovee, K. D. 1982. A guide to stream habitat analysis using the Instream Flow Incremental Methodology. Instream Flow Information Paper 12. U.S.D.I. Fish and Wildlife Service, Office of Biological Sciences. FWS/OBS-82/26. 248 pp.

Bray, D. I. 1972. Generalized Regime-Type Analysis of Alberta Rivers. Ph.D. Thesis. Department of Civil Engineering. University of Alberta. 232 pp. Appendices A to L.

Caissie, D. and N. El-Jabi. 1995. Comparison and Regionalization of Hydrologically Based Instream Flow Techniques in Atlantic Canada. Canadian Journal of Civil Engineering 22:235-246. 
Clipperton, G.K., C.W. Koning, A.G.H. Locke, J.M. Mahoney and B. Quazi. 2003. Instream Flow Needs Determinations for the South Saskatchewan River Basin, Alberta, Canada. Alberta Environment, Edmonton AB.

Cushing, C. E. and six others. 1980. Comparative Study of Physical-Chemical Variables of Streams Using Multivariate Analyses. Archive fur Hydrobiologie, 89, 343-352.

Cushing, C. E. and six others. 1983. Relationships Among Chemical, Physical, and Biological Indices Along River Continua based on Multivariate Analyses. Archive fur Hydrobiologie, 98, 317-326.

De Vries P., D. W. Reiser, and M. P. Ramey. 1999. A Proposed Classification Program for Determining Regional Instream Flow Needs in Alberta. Prepared for Alberta Environmental Protection, Natural Resources Service.

Dingman, S. L. and S. C. Lawlor. 1995. Estimating Low-Flow Quantiles from Drainage-Basin Characteristics in New Hampshire and Vermont. Water Resources Bulletin 31(2):243256.

Fernet, D.A., C.P. Bjornson, and J.J. Helwig. 1992. Willow Creek instream flow needs investigations: Fisheries component. Alberta Environmental Protection, Edmonton, AB. 108p. +App.

Furse, M. T., D. Moss, J. F. Wright, and P. D. Armitage. 1984. The Influence of Seasonal and Taxonomic Factors on the Ordination and Classification of Running-Water Sites in Great Britain and on the Prediction of their Macro-Invertebrate Communities. Freshwater Biology, 14, 257-280.

Geller, L.D. [ed.]. 2003. A guide to instream flow setting in Washington State. Washington Department of Ecology and Washington Department of Fish and Wildlife. Publication No. 03-11-007. http://www.ecy.wa.gov/biblio/0311007

Golder Associates Ltd. (Golder). 2001. Alberta IFN Classification Assessment Project. Alberta Sustainable Resource Development, Alberta Environment and Department of Fisheries and Oceans Canada. Cochrane, AB. 
Golder Associates Ltd. (Golder). 2002. Alberta IFN Classification Assessment Project: Scoping of Year II Field Program. Fisheries and Oceans Canada, Edmonton, AB and Alberta Sustainable Resource Development, Cochrane, AB.

Hallisey, J.E. and G. H. Belt. 1996. Relationships between Particle Movement and Channel Morphology in Some Northern Idaho Streams. Water Resources Bulletin 32(2):383-391.

Hatfield, T. and J. Bruce. 2000. Predicting salmonid habitat-flow relationships for streams from western North America. North American Journal of Fisheries Management 20: 10051015.

Hardy, T. B. 2000. A Conceptual Framework and Technical Approach for Assessing Instream Flow Needs in the Water Resources Inventory Area No. 1 (WRIA1) in Washington State.

Hardy, T.B. 2002. WRIA 1 Watershed Management Project: Instream Flow Extrapolation Workshop Summary. 11 pp.

Henderson, F. M. 1966. Open Channel Flow. Macmillan Publishing Co., Inc.

Hogan, D. L. and M. Church. 1989. Hydraulic Geometry in Small, Coastal Streams: Progress Toward Quantification of Salmonid Habitat. Canadian Journal of Fisheries and Aquatic Science 46:844-852.

Kellerhals, R., C. R. Neill and D. I. Bray. 1972. Hydraulic and Geomorphic Characteristics of Rivers in Alberta. River Engineering and Surface Hydrology Report 72-1. Research Council of Alberta.

Lamouroux, N. and H. Carpa. 2002. Simple predictions of instream habitat model outputs for target fish populations. Freshwater Biology 47: 1543-1556.

Lamouroux, N., H. Carpa and M. Pouilly. 1998. Predicting habitat suitability for lotic fish: linking statistical hydraulic models with multivariate habitat use models. Regulated Rivers: Research and Management 14: 1-11. 
Lamouroux, N. and Y. Souchon. 2002. Simple predictions of instream habitat model outputs for fish habitat guilds in large streams. Freshwater Biology 47: 1531-1542.

Lamouroux, N. Y. Souchon and E. Herouin. 1995. Predicting velocity distributions in stream reaches. Water Resources Research 31: 2367-2375.

Leclerc R. and M. F. Lapointe. 1994. Hydraulic Geometry of Alluvial Rivers in the Bois-Francs Region of Southern Quebec. Canadian Water Resources Journal 19(3):237-252.

Leopold, L. B., Wolman, M. G., and Miller, J. P. 1964. Fluvial Processes in Geomorphology. Dover Publications, Inc, New York, 522 pp.

Longmore L. A. and C. E. Stenton. 1981. The Fish and Fisheries of the South Saskatchewan River Basin: Their Status and Environmental Requirements. Prepared for Planning Division, Alberta Environment.

Mosley, M. P. 1981. Delimitation of New Zealand Hydrologic Regions. Journal of Hydrology 49:173-192.

Mosley, M.P. 1987. The classification and characterization of rivers. In Richards, K. (Ed.): River channels: environmental processes, 295-320. Blackwell, London.

Olson, T. 1994. Analysis of Tessman Flow Recommendations for Alberta Streams (Draft). Prepared for Alberta Environmental Protection, Fish and Wildlife Service.

Olson, T. 1994. Evaluation of Average Flow Percentages as Instream Flow Recommendations for Alberta Streams (Draft). Prepared for Alberta Environmental Protection, Fish and Wildlife Service.

Reiser, D.W. 1995. Affidavit of Dudley W. Reiser in support of Nez Perce Instream Flow Claims, Case No. 39576, in the District Court of the State of Idaho, in and for the County of Twin Falls. 
Reiser, D.W. 1998. Affidavit of Dudley W. Reiser in support of Nez Perce Instream Flow Claims, Case No. 39576, in the District Court of the State of Idaho, in and for the County of Twin Falls.

Reiser, D. R. and P. DeVries. 1996. Review of the Alberta Method for Developing Instream Flow Needs (IFN) Recommendations. Prepared for Alberta Environmental Protection.

Rogerson, R. J. 1986. Sedimentary and geomorphic Characterization of Channel Environments in the West Salmon River, Central Newfoundland, with Emphasis on Examination of Salmonid Spawning Habitat. Prepared for Department of Fisheries and Oceans.

Rosgen, D. and H. L. Silvey. 1998. Field Guide for Stream Classification. Wildland Hydrology Books.

Saraeva, E. and T. Hardy. 2004. Development and Application of a GIS Based Instream Flow Extrapolation Procedure for Watershed Planning in the Nooksack River Basin. To be presented at $5^{\text {th }}$ International Symposium on Ecohydraulics, Madrid, Spain, September 12-17, 2004.

Singh, K. P., S. M. Broeren, and R. B. King. 1986. Interactive Basinwide Model for Instream Flow and Aquatic Assessment. Illinois State Water Survey Division. SWS Contract Report 394.

Swift, C.H., III. 1976. Estimation of stream discharges preferred by steelhead trout for spawning and rearing in western Washington. U.S. Geological Survey Open-File Report 75-155. Tacoma, Washington: U.S. Geological Survey.

Swift, C.H., III. 1979. Preferred stream discharges for salmon spawning and rearing in Washington. U.S. Geological Survey Open-File Report 77-422. Tacoma, Washington: U.S. Geological Survey.

Susquehanna River Basin Commission. 1998. Instream Flow Studies - Pennsylvania and Maryland. Summary Report. Publication 191A. 
Wolman, M. G., and J. P. Miller. 1960. Magnitude and frequency of forces in geomorphic processes. J. Geology 68(1): 54-74. $522 \mathrm{pp}$.

Wright, J. F., D. Moss, P. D. Armitage, and M. T. Furse. 1984. A Preliminary Classification of Running Water Sites in Great Britain Based on Macro-Invertebrate Species and the Prediction of Community Type Using Environmental Data. Freshwater Biology, 14, 221256. 



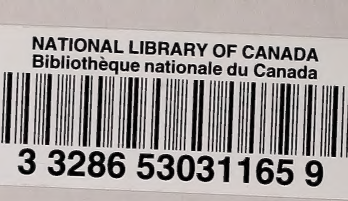

